\title{
FACING THE NATION: THE STANDARDS FOR COPYRIGHT, INFRINGEMENT, AND FAIR USE OF FAGTUAL WORKS
}

\author{
Gary L. Francione ${ }^{\dagger}$ \\ Table of Contents
}

INTRODUCTION .................... 520

I. The Nation: An Examination of Different APPROACHES To Copyright ANALYSIS ........... 523

A. The Separate Opinions............... 523

1. The District Court: The Totality Theory ... 525

2. The Court of Appeals: Facts as the "Prop-

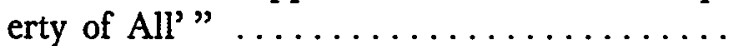

3. The Supreme Court: Fair Use and Unpublished Memoirs ................... $\quad 530$

B. The Basic Features of Copyright Law That Explain the Divergent Approaches in The Nation . 536

II. Truncation of FaIR UsE IN The Nation ......... 544

III. ThE "TOTALITY" APPROACH TO ANALYzING INFRINGement Claims . . . . . . . . . . . . . .

A. Totality Analysis and the Subject Matter of In-

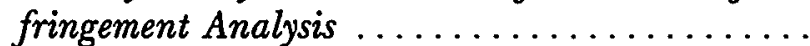

1. Oxford: A Gontrast in Approaches ........

2. The Traditional Test of "Substantial Similarity": The Totality Approach Accepted and

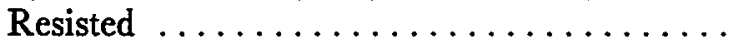

3. The Need for a Narrower Role for Factfinders in Infringement Determinations .

B. Totality Analysis and the Standard for Infringe-

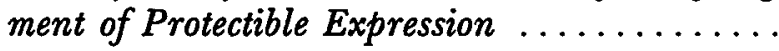

- Copyright 1986 by Gary L. Francione. All rights reserved.

† Assistant Professor of Law, University of Pennsylvania. B.A. 1976, University of Rochester; M.A./J.D. 1981, University of Virginia. I gratefully acknowledge the comments received from my colleagues at the University of Pennsylvania: Ed Baker, Steve Burbank, Seth Kreimer, Ralph Spritzer, and Alan Watson. Bob Gorman provided especially helpful guidance and encouragement. My research assistant, Melanie Genkin, and my secretary, Joanne Burne, were invaluable. The A. Leo Levin Fund provided research support. 
1. Infringement and the Limitations of Factual Expression ................... 570

2. Conflation of Infringement and Fair Use ... 575

C. Totality Analysis and "Wholesale Usurpation" of Expression ......................... 579

1. Wholesale Usurpation of Research or Labor 582

2. Wholesale Usurpation and Fair Use ...... 586

3. Wholesale Usurpation and Protectible Ar-

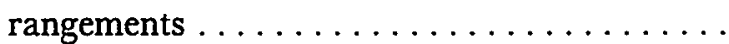

Gonclusion $\ldots \ldots \ldots \ldots \ldots \ldots \ldots \ldots \ldots \ldots \ldots \ldots$

\section{INTRODUCTION}

In its recent decision in Harper \& Row, Publishers v. Nation Enterprises ${ }^{1}$ (The Nation), the Supreme Court acknowledged that "[e]specially in the realm of factual narrative, the law is currently unsettled regarding the ways in which copyrightable elements combine with the author's original contributions to form protected expression."2 The Court's acknowledgment reflects the considerable confusion that characterizes judicial analysis of copyright infringement claims involving factual works, or "works which compile and communicate factual information about our society and the world about us, past and present. ${ }^{\text {"3 }}$ Examples of such works include business reports, ${ }^{4}$ maps, ${ }^{5}$ legal ${ }^{6}$ and business forms, ${ }^{7}$ and historical ${ }^{8}$ and biographical narratives. ${ }^{9}$ If the world is not to "be deprived of improvements, or the progress of the arts ... retarded," "then factual works must be broadly disseminated. ${ }^{10}$ The difficulty arises in the context of determining under what circumstances, if any, noncopyrightable factual materials may receive some measure of protection by being combined with copyrightable material into a protectible totality.

1105 S. Ct. 2218 (1985).

2 Id. at 2224.

- Gorman, Fact or Fancy? The Implications for Copyright, 29 J. Copyright Soc'y 560, 561 (1982).

- See, e.g., Wainwright Sec. Inc. v. Wall St. Transcript Corp., 558 F.2d 91 (2d Cir. 1977), cert. denied, 434 U.S. 1014 (1978).

- See, e.g., Key Maps, Inc. v. Pruitt, 470 F. Supp. 33 (S.D. Tex. 1978).

- See, e.g., Donald v. Zack Meyer's T.V. Sales \& Serv., 426 F.2d 1027 (5th Cir. 1970), cert. denied, 400 U.S. 992 (1971).

7 See, e.g., Baker v. Selden, 101 U.S. 99 (1879).

see, e.g., Hoehling v. Universal City Studios, 618 F.2d 972 (2d Cir.), cert. denied, 449 U.S. 841 (1980).

See, e.g., Rosemont Enters. v. Random House, Inc., 366 F.2d 303 (2d Cir. 1966), cert. denied, 385 U.S. 1009 (1967).

${ }_{10}$ Id. at 307 (quoting Sayre v. Moore, 102 Eng. Rep. 138, 139 (K.B. 1801)). 
This confusion concerning factual works is illustrated dramatically in the analyses of the district court, court of appeals, and Supreme Court opinions in The Nation. The issue presented was whether appropriation by a news magazine, The Nation, of portions of the then unpublished memoirs of former President Gerald Ford constituted copyright infringement. The district court recognized that the historical facts and other factual material contained in the memoirs were not per se copyrightable, ${ }^{11}$ but argued that because those facts were necessary parts of Ford's own personal revelation, the factual materials and revelations merged to become a protected totality infringed by The Nation's use. ${ }^{12}$ The district court also held that the use did not qualify as a "fair use" under the 1976 Copyright Act. ${ }^{13}$ The court of appeals rejected the totality theory, holding that only the literal expression or direct quotation of the factual elements was protectible and that the fair use doctrine protected the limited use of verbatim quotations of the memoirs by The Nation. ${ }^{14}$ The Supreme Court, ostensibly focusing only on the fair use question as it concerned the verbatim quotations, reversed the court of appeals and found that the appropriation of literal expression by The Nation did not constitute fair use. ${ }^{15}$ The Court thereby appeared to have avoided the need to address explicitly the merits of the totality theory, but the Court adopted some of the district court's findings, which were predicated on the totality approach, in its own fair use

11 See Harper \& Row, Publishers v. Nation Enters., 557 F. Supp. 1067, 1072 (S.D.N.Y.), rev'd, 723 F.2d 195 (2d Cir. 1983), rev'd, 105 S. Ct. 2218 (1985).

12 See id.

13 See id. (construing the 1976 Copyright Act, 17 U.S.C. $\$ \S 101-810$ (1982)). "Fair use" was originally a judicially created privilege to use copyrighted material, and in 1976 was embodied in the copyright statute. The statutory embodiment of the doctrine provides that

[n]otwithstanding the provisions of section 106, the fair use of a copyrighted work, including such use by reproduction in copies or phonorecords or by any other means specified by that section, for purposes such as criticism, comment, news reporting, teaching (including multiple copies for classroom use), scholarship, or research, is not an infringement of copyright. In determining whether the use made of a work in any particular case is a fair use the factors to be considered shall include-

(1) the purpose and character of the use, including whether such use is of a commercial nature or is for nonprofit educational purposes;

(2) the nature of the copyrighted work;

(3) the amount and substantiality of the portion used in relation to the copyrighted work as a whole; and

(4) the effect of the use upon the potential market for or value of the copyrighted work.

17 U.S.C. $\S 107$ (1982).

14 See Harper \& Row, Publishers v. Nation Enters., 723 F.2d 195, 204-08 (2d

Cir. 1983), rev'd, 105 S. Ct. 2218 (1985).

is See $105 \mathrm{~S}$. C.t. at 2227-35. 
analysis. This adoption at least suggests that the Court viewed the district court's totality approach in a favorable light. ${ }^{16}$

The conflict evident among the radically different opinions in The Nation is symptomatic of copyright analysis of factual works generally. For decades, courts have struggled unsuccessfully with the application of copyright doctrines to factual works. Most courts have tended toward accepting various forms of the "totality approach." This approach may be defined as any legal theory that accords noncopyrightable facts some measure of copyright protection when these facts are somehow combined with copyrightable expression into a protectible totality. The totality approach has taken three distinct forms. First, courts have defined copyrightable expression to include noncopyrightable facts for purposes of determining whether a subsequent writing is substantially similar to the expression alleged to be infringed. ${ }^{17}$ Second, courts have applied the same standard of infringement to factual and fictional expression. ${ }^{18}$ Third, courts have applied a theory called "wholesale usurpation," 19 according to which courts find infringement of copyright in factual works if the subsequent user appropriates "the total entity with its unique and protected mosaic," comprising the overall arrangement and selection of facts. ${ }^{20}$

Until the Supreme Court's decision in The Nation, it was not necessary either as a matter of copyright doctrine or for first amendment purposes to face the complex task of formulating coherent standards for the copyright and infringement of factual works. The reason it was not necessary is that the fair use doctrine was a "cure-all" for the problems in this area. Irrespective of whether factual works were accorded broad copyright protection, an expansive interpretation of the fair use doctrine was always available and often utilized to protect the subsequent use and dissemination of factual information.

In The Nation, however, the Supreme Court appears to have placed the cure-all of fair use in a very small bottle by truncating substantially the fair use defense. ${ }^{21}$ As a result, the dissemination of factual works is being squeezed dangerously from both sides of copyright doctrine. On one side, judicial approval of the totality approach in any of its forms provides excessive copyright protection to factual works. On the other side, the doctrine of fair use, previously used by courts and

\footnotetext{
16 See infra text accompanying notes 86-91.

17 See infra notes $178-241$ and accompanying text.

${ }^{18}$ See infra notes $242-81$ and accompanying text.

19 E.g., Hoehling v. Universal Gity Studios, 618 F.2d 972, 980 (2d Cir. 1980).

${ }^{20}$ The Nation, 723 F.2d at 203; see also infra notes 282-366 and accompanying

21 See infra notes $135-73$ and accompanying text.
} text. 
recommended by commentators as a means of legitimizing some uses of factual works, ${ }^{22}$ will, in all likelihood, now fail to excuse the increased infringement that results from this broader protection. Unless some judicial or legislative action is taken, this double squeeze threatens to impede the dissemination of such works to a degree prohibited by the Constitution and copyright statutes.

In Part I of this Article, I examine briefly the three opinions in The Nation in order to highlight the different copyright approaches apparent in the opinions. I then set out some of the features of copyright law that account for the tension underlying these different approaches to copyright analysis. Part II examines how the Supreme Court's opinion in The Nation has restricted fair use analysis in ways that will increase the number of infringement claims involving factual works. This restricted fair use doctrine necessitates that courts begin to unravel the confusion that has infected copyrightability and infringement doctrines, because these doctrines will remain the only means by which courts will be able to ensure the continued broad dissemination of factual works. In Part III, I explore the confusion in copyrightability and infringement doctrines caused by the combination of unprotectible elements into totalities protectible by copyright law. I demonstrate the inadequacies of the various forms of the totality approach, and also take issue with those commentators who support the expanded copyright protection represented by totality analysis. The thrust of my argument is that because some limited version of the fair use doctrine is here to stay, and perhaps appropriately so, the basic purposes of copyright law, as well as the first amendment, would best be served by rejecting all forms of the totality approach.

\section{The Nation: AN Examination of Different Approaches to COPYRIGHT ANALYSIS}

\section{A. The Separate Opinions}

Shortly after Gerald Ford left the White House, he entered into an agreement with Harper \& Row and Reader's Digest, Inc. (the "publishers") to prepare his memoirs for publication. Although it was

${ }^{22}$ See, e.g., Denicola, Copyright in Collections of Facts: A Theory for the Protection of Nonfiction Literary Works, 81 ColuM. L. REv. 516 (1981); Patry, Copyright in Collections of Facts: A Reply, in CuRRENT Developments IN Copyright LAW 627 (D. Goldberg ed. 1985); Ginsburg, Sabotaging and Reconstructing History: $A$ Comment on the Scope of Copyright Protection in Works of History After Hoehling v. Universal City Studios, 29 J. Copyright Soc'y 647 (1982); Gorman, supra note 3; Gorman, Copyright Protection for the Collection and Representation of Facts, 76 HaRv. L. ReV. 1569 (1963). 
understood that the memoirs would not contain "sensational" revelations, the agreement specified that Ford would present previously unpublished material concerning his relationship with former President Richard Nixon, Nixon's reaction to the Watergate crisis, Ford's pardon of Nixon, and Ford's "reflections on this period of history, and the morality and personalities involved."23 Ford granted the exclusive right to publish the memoirs as a book, as well as certain exclusive rights "to exercise, sell, license or otherwise dispose of any and all of the subsidiary rights" prior to publication. ${ }^{24}$ The extensive interview, research, and initial drafting were done by a professional writer hired by Ford.

On March 14, 1979, the publishers granted an exclusive license to Time, Inc. ("Time"), to publish excerpts from the memoirs that focused on Nixon's resignation and pardon. This issue of Time magazine was to go on sale on April 16, 1979. ${ }^{25}$ Time agreed to pay the publishers $\$ 25,000$ for the license, one-half payable upon execution of the licensing agreement, and the remainder upon Time's publication of the excerpts. ${ }^{26}$ The agreement between the publishers and Time provided that the parties would use reasonable effort to keep the licensed material confidential and that any publication prior to or simultaneous with Time's publication would give Time the right to renegotiate the second payment. As a result, Harper \& Row required all of its employees who had access to the manuscript to sign an agreement to keep the memoirs confidential. ${ }^{27}$

Sometime late in March 1979, Victor Navasky, editor of The $\mathrm{Na}$ tion, a political commentary and news magazine, received a copy of the Ford manuscript from an unidentified source who Navasky knew was not authorized to provide the manuscript. Navasky did not know at the time he received possession that Time was licensed to publish excerpts, and believing that the manuscript contained important political material, he decided to publish an article based on material contained in the memoirs. ${ }^{28}$ The article, which was approximately 2250 words in length, appeared in The Nation on April 3, 1979.29 The article con-

23 Joint Appendix at JA-486, The Nation.

24 Id. at JA-481.

25 Petition for a Writ of Certiorari to the United States Court of Appeals for the Second Circuit at 6, The Nation.

${ }^{26} I d$.

27 See id. at C19-C20.

${ }^{28}$ See The Nation, 723 F.2d at 198.

${ }^{29}$ Id. The article was appended to the district court opinion, see $557 \mathrm{~F}$. Supp. at 1073 app., the court of appeals opinion, see 723 F.2d at 209 app., and the Supreme Court opinion, see $105 \mathrm{~S}$. C. at 2236 app. The article discusses Ford's pardon of Nixon when Nixon was ill with phlebitis, Ford's comments on Nixon's character, Ford's interaction with various political figures, and Ford's decision to run again for 
tained material on Nixon's resignation and pardon, but also included material apparently not to be excerpted and published by Time. When Time learned of The Nation's article, it sought permission to print the excerpts in an earlier issue of Time. The publishers refused, and Time neither printed any excerpts nor paid the remaining $\$ 12,500 .^{30}$ The publishers then sued The Nation for copyright infringement and for various state-law violations. ${ }^{31}$

\section{The District Court: The Totality Theory}

The district court began its analysis by noting that because the memoirs were protected by copyright, The Nation article was "an infringement of that copyright, unless otherwise privileged."32 The court examined, and rejected, three arguments made by the defendants. One argument the court rejected was the defendants' fair use defense, ${ }^{33}$ which relied on the theory that the memoirs were "news." The court held that the article was not news because, as Navasky had acknowledged, what Navasky considered to be newsworthy in his story had been previously recounted in other sources. ${ }^{34}$ The court then assessed

the presidency. It concludes with a brief comment on the propriety of Navasky's disclosure of the material.

${ }^{30}$ See The Nation, 723 F.2d at 199.

31 The district court granted a motion to dismiss the state-law claims on the ground that they were preempted by the 1976 Copyright Act, 17 U.S.C. $\S 101-810$ (1982). See The Nation, 501 F. Supp. at 853-54 (citing 17 U.S.C. $\S 301$ ). The publishers later filed an amended complaint that was denied on the same ground. The Second Circuit affirmed the dismissal of the state-law claims; the court agreed that the claims were preempted by the Copyright Act. See The Nation, 723 F.2d at 199-201.

32 The Nation, 557 F. Supp. at 1070. In connection with the issue of copyright protection for the memoirs, the court noted that the memoirs constituted a "literary work" within the meaning of 17 U.S.C. $\S 102(a)(1)(1982)$, and that the original publishing agreement between the publishers and Ford was recorded in accordance with 17 U.S.C. § 205(d) (1982). See 557 F. Supp. at 1070 n.3.

ss See supra note 13.

s4 See 557 F. Supp. at 1070-72. Specifically, Navasky testified that he believed certain portions of the memoirs relating to conversations between Ford and White House Chief of Staff Alexander Haig were "hot news." See id. at 1070-71. Haig had suggested to Ford that Nixon's resignation might be made contingent on Ford's pardon. See id. at 1074 app. (text of the article in The Nation). Navasky also testified that he believed that "there was possibly an obstruction of justice in the transaction and in the story." Id. at 1070-71 (footnote omitted). The court determined that Navasky's views about a possible obstruction of justice were based on "sheer speculation," $i d$. at 1070 n.6, and noted that the Ford-Haig conversations had been revealed by Ford in an appearance before a congressional committee in 1974. See id. at 1071. The court also pointed out that a potentially newsworthy memorandum by Henry S. Ruth, Jr., an assistant to Watergate Special Prosecutor Leon Jaworski, to Jaworski had already been revealed in a book by Jaworski. See id. at 1071 n.9. 
the individual fair use factors and found none of them to be applicable:

First, the article was published for profit. Second, the infringed work was soon-to-be published. Third, The Nation took what was essentially the heart of the book, and fourth, the effect of The Nation's extensive use of the Nixon pardon material caused the Time agreement to be aborted and thus diminished the value of the copyright. ${ }^{35}$

Another argument that the defendants made was that, notwithstanding any copyright in the memoirs, the defendants' use was protected by the first amendment. ${ }^{36}$ The court rejected this argument in a footnote, maintaining that "[w]hile there may be a circumstance in which the First Amendment provides a defendant with greater protection than the fair use doctrine," this was not such a circumstance. ${ }^{37}$

Finally, The Nation argued that copyright protection could not extend to those portions of Ford's memoirs concerned with historical facts, texts of government memoranda prepared by individuals other than Ford, and quoted statements of persons other than Ford. If these allegedly noncopyrightable materials were removed from consideration, the defendants argued, any taking of the remaining copyrightable material would be excusable. Although the court acknowledged that these categories of materials were not "per se copyrightable,"ss the court decided that they were "integral and necessary components of the context of Ford's revelations as to his state of mind"s9 and, therefore, that the "totality" of the noncopyrightable elements, together with Ford's revelations about them, was "protected by the copyright laws." 40

ss Id. at 1072 (footnotes omitted). The Nation also argued that Time was willing to print the excerpts if the publishers would allow it to do so earlier than originally agreed. The court observed that the publishers declined Time's request because the difference of one week would create an unacceptably long interval between Time's publication of the excerpts and the availability of the book in bookstores. The court refused "to second-guess the plaintiffs' business judgment in this regard." Id. at 1072 n.11.

${ }^{38}$ See id. at 1070 n.4.

sz Id.

${ }^{38}$ Id. at 1072 . With respect to the portions of the memoirs that recited statements of others, the court declined to attempt to separate exact quotations from reconstructions. The court suspected that "most [statements] were to some degree reconstructions." Id. at 1073.

so Id. at 1073. The Second Circuit expressed confusion over the meaning of "revelations" in the district court opinion. See infra note 58.

10 See 557 F. Supp. at 1072. This view of the copyrightability of the "totality" could be anticipated by the court's earlier statement that because the memoirs were protected by copyright, Navasky's article was an infringement unless privileged. The district court's statement that facts are "not per se copyrightable" reflected the court's view that facts could be given protection under certain circumstances, such as when the facts are "integral and necessary components of the context of Ford's revelations as to his state of mind." The locution used throughout this Article is that facts are "per se 
2. The Court of Appeals: Facts as the " 'Property of All" "41

On appeal, the court of appeals reversed the district court on the issue of copyright infringement. ${ }^{42}$ Unlike the trial court, which had discussed issues of copyrightability only after it considered the defendant's fair use arguments, the Second Circuit began its analysis with the issue whether the material used by Navasky was copyrightable. In its somewhat convoluted discussion of this issue, the court emphasized the distinction between ideas and facts, which are not protectible, and expression, which is protectible. ${ }^{43}$ This distinction, according to the court, ensures that the copyright monopoly does not create an "intolerable limitation on First Amendment rights." "44 The first amendment values served by the distinction were particularly acute in this case:

Nowhere could the need to construe the concept of copyrightability in accord with First Amendment freedoms be more important than in the instant case. Here we are presented with an article describing political events of major significance, involving a former President of the United States. The paraphrasings concern the very essence of news and of history. ${ }^{45}$

The idea/expression or fact/expression distinction informed by these heightened first amendment concerns guided the Second Circuit's determination of copyrightability in four salient respects. First, although the court noted that Ford's actual expression was protected by copyright, it 'confined that troublesome concept 'expression' to its barest elements-the ordering and choice of the words themselves." The court expressed no doubt that Ford's verbatim language was pro-

noncopyrightable," which reflects the view that facts cannot be made copyrightable through the merger of fact and expression. It is recognized that both locutions are question begging to some degree, because each reflects a conclusion about the totality approach.

${ }^{41}$ The Nation, 723 F.2d at 209 (quoting Hoehling v. Universal City Studios, 618 F.2d 972, 974 (2d Cir.), cert. denied, 449 U.S. 841 (1980)).

12 See id. The Second Circuit affirmed the district court's dismissal of the statelaw claims. See id. at 199-201.

4 See id. at 202-04.

14 Id. at 204 n.12 (quoting $1 \mathrm{M}$. NIMMER, NIMMER ON COPYRIGHT $\S 2.11[\mathrm{E}]$ (1985)).

${ }_{45} I d$. at 204.

48 Id. The court cited Hoehling v. Universal City Studios, 618 F.2d 972 (2d Cir.), cert. denied, 449 U.S. 841 (1980), for the proposition that the first amendment requires that protectible expression be understood as involving only the ordering and choice of actual words. See 723 F.2d at 204. This interpretation suggests that the court did not confine its first amendment concerns to political matters, but extended it to include works of history as well. 
tected, ${ }^{47}$ but it also made clear that conversations and documents attributed to those other than Ford ${ }^{\mathbf{4 8}}$ and information previously presented in a government document ${ }^{49}$ could not receive copyright protection.

Second, the court held that the "definitional balance between the First Amendment and the Copyright Act [that] permit[s] the free communication of facts while still protecting an author's expression" quired that paraphrasing of discrete facts be permitted. To hold otherwise, the court asserted, "ignores the unambiguous legislative history which establishes that 'information' is not protected." Infringement in this context would, therefore, require that the user paraphrase the entire work or all of a chapter. ${ }^{52}$

Third, the court stated that "[a]n author's originality exists, in part, in his overall arrangement of facts." ${ }^{\text {"53 }}$ Because Navasky's article "drew only upon scattered parts" of the work and therefore did not disrupt the "structure ... [of] the work as a whole," the court concluded that Ford's expression, represented in the "total entity with its unique and protected mosaic," was not in any way usurped. ${ }^{\text {s }}$ Navasky's use of the particular subset of factual material would not present a problem because those facts would not, in and of themselves, be subject to copyright protection.

Finally, the court rejected the trial court's totality theory-that even though the facts, memoranda, and conversations were not copyrightable, they somehow became protectible when "integral" to Ford's "revelations." The court reasoned that because Ford's literal words

47 See 723 F.2d at 204.

48 See id. at 205 . The court held that because such conversations and documents were not Ford's work they did not meet the statutory requirement of originality, see 17 U.S.C. $\S 102(a)$ (1982), and could not be protected. See 723 F.2d at 205.

49 See 723 F.2d at 205 (citing 17 U.S.C. $\$ 105$ (1982)). The court referred in particular to information that Ford had presented to a congressional subcommittee. See $i d$. (citing Pardon of Richard M. Nixon, and Related Matters: Hearings Before the Subcomm. on Criminal Justice of the House Comm. on the Judiciary, 93d Cong., $2 \mathrm{~d}$ Sess. 90-151 (1974)).

so Id. at 203.

s1 Id. at 204 (citing H.R. REP. No. 1476, 94th Cong., 2d Sess. 56, reprinted in 1976 U.S. Code Cong. \& Ad. News 5659, 5670).

s2 See id. at 203.

ss Id.

of Id.

${ }^{85}$ Id. at 204. There is some confusion about the meaning of "revelations" and "reflections" in both the district court and court of appeals opinions. It is unclear whether the district court meant that Ford's actual utterance of factual information somehow transformed the noncopyrightable information into copyrightable information, or whether it meant that Ford's assertions about his mental processes together with his factual utterances combined to create the protectible "totality." The district court stated that the factual information, memoranda, and third-party statements were "integral and necessary components of the context of Ford's revelations." 557 F. Supp. at 1073. 
were "unquestionably copyrightable" and because most of the "revelations" in question were taken verbatim from the memoirs, it was not necessary to determine whether these revelations were properly characterized as fact or as expression. ${ }^{56}$ The court noted, however, that it would "defy common sense" to treat Ford's "states of mind" about political decisions as any less factual than public acts, especially if those "states of mind" were described in other than Ford's words. ${ }^{\text {s8 }}$

The court concluded that once these copyrightability issues were resolved, the only remaining material that Navasky could have infringed consisted of approximately 300 words that were taken verbatim from the memoirs and that did not represent quotations of third parties or material from other unprotectible sources. ${ }^{5 \theta}$ The court rejected the trial court's analysis that Navasky's article failed to be "good or genuine news" and stressed that neither the statute: nor the case law required that fair use be determined by how well Navasky performed his task. ${ }^{60}$ The issue then became whether Navasky's use of these 300 words constituted a fair use under section 107 of the Copyright Act. ${ }^{61}$

Turning to its fair use analysis, the court of appeals declared the district court's analysis erroneous with regard to each individual factor. Despite the trial court's finding that the "article was published for profit," "B2 the Second Circuit noted that profit was "legally irrelevant" when public benefit was involved..$^{83}$ As for the "nature of the copyrighted work," the court of appeals determined that because the memoirs were factual in nature, the district court erred when it declined to afford the work more narrow protection. ${ }^{64}$ Rejected also were the trial court's conclusions that Navasky had used "the heart of the book" and that the use had adverse economic impact on the publishers, because such findings were based on the trial court's incorrect totality analysis-that the noncopyrightable elements somehow "merged" into

It seems, therefore, that the district court thought that Ford's utterance of statements containing these data made them protectible.

The Second Circuit seemed to subscribe to the view that Ford's "revelations" referred to his "states of mind" relevant to the decisions described in Navasky's article. See 723 F.2d at $205 \&$ n.14. This reasoning suggests that the Second Circuit understood the district court's "totality" approach as combining Ford's assertions about his mental processes with his factual utterances.

${ }^{86}$ See 723 F.2d at 204.

s7 Id. at 205.

${ }^{88}$ See id. at 205 \& n.14.

s9 See id. at 206.

so See id. at 207.

61 17 U.S.C. $\S 107$ (1982), reprinted supra note 13.

62723 F.2d at 207 (quoting 557 F. Supp. at 1072).

6s See id. at 208.

- See id. 
protected expression by virtue of Ford's "reflections" and revelations. ${ }^{6 s}$

In light of the court of appeals' analysis of the fair use factors and its observation that the quoted portions, for the most part, gave "authenticity to this politically significant material" and provided "the reader with a means of evaluating" certain claims made by Ford, the court concluded that Navasky's minimal use of the copyrighted expression was a fair use. ${ }^{68}$ The court determined that " $[t] \mathrm{o}$ decide otherwise would be to ignore those values of free expression which have traditionally been accommodated by the statute's 'fair use' provisions."

\section{The Supreme Court: Fair Use and Unpublished Memoirs}

After its statement of the basic principles of copyright law and review of the lower court opinions, the Court, by Justice O'Connor, observed that "[p]erhaps the controversy between the lower courts in this case over copyrightability is more aptly styled a dispute over whether The Nation's appropriation of unoriginal and uncopyrightable elements encroached on the originality embodied in the work as a whole." 88 The Court concluded that it was not necessary to resolve the conflict over the proper standards for copyrightability of factual works ${ }^{68}$

${ }^{65}$ See id. at 208.

Bo See id.

${ }^{67}$ Id. Judge Meskill filed a dissenting opinion that took issue with the majority's analyses of both copyrightability and fair use. Regarding the former, Judge Meskill argued, inter alia, that the trial court's "totality analysis" was correct and that facts may be subject to copyright protection in such a way that paraphrasing of discrete facts may constitute infringement if the paraphrased work, or a work containing paraphrasing in combination with appropriated verbatim expression, results in a work that is substantially similar to the original work. See id. at 214 . Although Judge Meskill contended that protection for factual works does not imply protection for the facts themselves, he nevertheless seemed to confuse these issues. See id. at $202 \mathrm{n} .8$. He also argued that the permissible use of facts by a second author required that the author add something "original" to the prior work. See id. at 214.

Turning to the fair use analysis, Judge Meskill first agreed with the majority that "[c]ourts should be chary of deciding what is and what is not news." Id. at 215 . He then went on to argue, however, that the proper coverage of a news event must "contain original material," and that Navasky could not properly rely exclusively on the copyrighted memoirs for his news story, See id. at 215. In Judge Meskill's view, Navasky appropriated "some of the most vivid parts of the book," and this appropriation went beyond what was necessary to write a news article. See id. at 216. Judge Meskill also determined that the article in The Nation represented an instance of commercial exploitation that created a "substantial incursion" into the market for the primary work. See id.

${ }_{68}$ The Nation, $105 \mathrm{~S}$. Ct. at 2224. Actually, the controversy between the court of appeals and the district court focused more on the proposition advanced by the district court, and rejected by the Second Circuit, that elements of Ford's memoirs acknowledged not to be per se copyrightable became copyrightable as a "totality" when combined with Ford's "reflections" and "revelations" about those elements.

${ }^{68}$ Curiously, the Court cited Wainwright Sec. Inc. v. Wall St. Transcript Corp., 
because "[t]he Nation has admitted to lifting verbatim quotes of the author's original language totalling between 300 and 400 words and constituting some $13 \%$ of The Nation article." ${ }^{\text {" I } 0}$ In the Court's view, this use "was not a fair use within the meaning of the Copyright Act, ${ }^{\text {"71 }}$ and the first amendment provided no protection apart from the fair use defense. ${ }^{72}$

It is curious that the Court chose to focus on the fair use doctrine, rather than the dispute between the district court and court of appeals concerning the extent to which copyright protection could be used to protect factual material. Whether fair use exists in any particular case is generally an issue of fact ${ }^{73}$ or a mixed issue of law and fact, ${ }^{74}$ that requires the trier of fact to apply an ill-defined "equitable rule of reason' "75 on an ad hoc basis. Appellate courts usually engage in such analysis only when the facts found by the trial court are sufficient to allow the appellate court to evaluate the fair use factors, which are inherently fact specific. ${ }^{76}$ The Court in The Nation recognized the factual nature of the fair use inquiry, but determined that the district court had done sufficient factfinding to permit a fair use inquiry at the appellate level. ${ }^{77}$ The problem here is that the district court never fo-

558 F.2d 91 (2d Cir. 1977), cert. denied, 434 U.S. 1014 (1978), and Hoehling v. Universal City Studios, 618 F.2d 972 (2d Cir.), cert. denied, 449 U.S. 841 (1980), as cases presenting two different treatments of the copyrightability of factual material. Conversely, the Second Circuit majority saw no inconsistency or conflict between Wainwright and Hoehling and relied on both to support its view on copyrightability. See 723 F.2d at 202. Judge Meskill in dissent agreed that there was no inconsistency between the two cases, but thought they both supported the contrary view. See id. at 212-16.

70 The Nation, $105 \mathrm{~S}$. Ct. at 2225. It appears that the 300-400 words to which the Court referred were the verbatim quotes discussed by the Second Circuit in its fair use analysis. See id. at 2233 n.8. The Court noted that although it did not consider quotations attributed to persons other than Ford or quotations from government documents to be "potentially infringing," these exclusions were not intended "to endorse any particular rule of copyrightability." Id.

71 Id. at 2225. The district court's findings related to its "totality" analysis; the district court made no findings for the purpose of evaluating fair use that focused on Navasky's use of the verbatim expression. Nevertheless, the Court determined that the district court "found facts sufficient to evaluate each of the statutory factors." Id. at 2231.

72 See id. at 2228-30.

7s See 3 M. Nimmer, NMMMER ON COPYRIGHT § 13.05 (1985).

74 See Pacific \& S. Co. v. Duncan, 744 F.2d 1490, 1495 n.8 (11th Cir. 1984), cert. denied, 105 S. Ct. 1867 (1985).

${ }_{78}$ Sony Corp. v. Universal City Studios, 464 U.S. 417, 448 \& n.31 (1984) (citing H.R. REP. No. 1476, 94th Cong., 2d Sess. 65-66, reprinted in 1976 U.S. CodE Cong. \& AD. NEws 5659, 5679-80).

${ }_{76}$ See, e.g., Pacific \& S. Co. v. Duncan, 744 F.2d 1490, 1495 n.8 (11th Cir. 1984), cert. denied, 105 S. Ct. 1867 (1985).

${ }_{77}$ See 105 S. Ct. at 2231. The Court cited Pacific \& S. Co. v. Duncan, 744 F.2d 1490 (11th Cir. 1984), cert. denied, 105 S. Ct. 1867 (1985), for the proposition that it was not necessary to remand for factfinding on the issue of fair use, and that the Court 
cused on the verbatim quotations, and its factfinding was entirely predicated on its totality analysis. These findings were then incorporated into the Court's fair use analysis in ways that will be explained below.

In connection with the first statutory factor of fair use-purpose and character of the use-the Court decided that although Navasky's article was arguably news, ${ }^{78}$ it was commercial in nature and was presumptively an unfair use under the Court's decision in Sony Corp. $v$. Universal City Studios. ${ }^{79}$ The Court also noted that the article had the intended purpose of "scooping" the book and Time magazine's prepublication, and that Navasky acted in bad faith because he "knowingly exploited a purloined manuscript." 80

As to the nature of the copyrighted work, the Court acknowledged that " $t]$ he law generally recognizes a greater need to disseminate factual works than works of fiction or fantasy," and that Navasky argua-

could decide the fair use issue " as a matter of law." " 105 S. Ct. at 2231 (quoting Duncan, 744 F.2d at 1495).

There are two problems with the Court's reliance on Duncan. First, in Duncan, the appellate court did not rely on factual findings that were predicated on a different concept of copyrightability than that accepted by the appellate court. In The Nation, by contrast, the Supreme Court stated that it was not necessary to pass on the validity of the district court's totality theory of copyright, but then, at least in part, adopted the district court's findings predicated on that approach. Second, there is some ambiguity in the Court's notion that the fair use issue can be decided as a "matter of law." The Court did not make clear whether it meant that if there are sufficient facts, the Court can engage in fair use balancing as would any trier of fact, or merely that reasonable minds could not conclude that Navasky had made a fair use of the quoted portions. If the Court meant the latter, then a problem still remains in that the Court decided the fair use issue as a matter of law by considering facts based on a totality theory of copyright that the Court claimed not to accept or reject. If the Court meant the former, then the Court should have remanded the case for findings on the fair use issue as those facts were applied to Navasky's use of the quoted materials. A remand would have accorded with the Court's usual practice under such circumstances-general avoidance of review or decision of factual issues. See, e.g., United States v. Johnston, 268 U.S. 220, 227 (1925).

${ }^{78}$ The Court so decided despite the fact that Justice O'Connor agreed with dissenting Judge Meskill's observation in the opinion below that "[c]ourts should be chary of deciding what is and what is not news." $105 \mathrm{~S}$. Ct. at 2231 (quoting The Nation, 723 F.2d at 215 (Meskill, J., dissenting)). Victor Navasky, in an editorial in the New York Times, remarked that the majority opinion "does just that." N.Y. Times, July 2, 1985, at A19, col. 2. According to Navasky, the Court had assumed that The Nation was making the same news that former President Ford would eventually make. What the Court failed to understand, claimed Navasky, is that "the same set of facts can . . . make vastly different points." Id. The Court had, concerning Ford's pardon of Nixon, "confused Mr. Ford's news-of-his-innocence with The Nation's news-of-hisguilt-both based on his own words and information." Id. Ultimately, Navasky saw The Nation decision as leaving the courts in "the news business for the foreseeable future." Id.

79 See 105 S. Ct. at 2231 (citing Sony Corp. v. Universal City Studios, 464 U.S. $417,451(1984))$.

${ }^{80} \mathrm{Id}$. at 2232. 
bly needed some of the verbatim quotations in order "adequately to convey the facts." 81 Nevertheless, two additional observations led the Court to weigh the second statutory factor against Navasky. First, the Court found that Navasky did not use only those verbatim quotations that might have been "so integral to the idea expressed as to be inseparable from it," but went beyond that and appropriated "subjective descriptions and portraits of public figures whose power lies in the author's individualized expression." 82 Second, and more importantly, the Court relied heavily on a presumption that "the scope of fair use is narrower with respect to unpublished works,"83 a notion that the Court also discussed at length in a separate portion of the opinion. ${ }^{84}$ The narrow fair use of an unpublished work served both to vindicate the statutory monopoly of the author insofar as personal interest and commercial exploitation are concerned and to protect the author's first amendment right not to speak publicly. ${ }^{85}$

In assessing a third factor, the amount and substantiality of the portion used, the Court accepted the district court's finding that "the Nation took what was essentially the heart of the book." "886 The Court stated that "the Court of Appeals erred in overruling the district judge's evaluation of the qualitative nature of the taking."

In referring to the "heart" of the book, the district court clearly believed that any use of the information relating to Ford's pardon of Nixon or to Nixon's resignation would have amounted to infringement, because this material "was the very part for which Time was willing to pay $\$ 25,000 . " 88$ Thus, in holding that the court of appeals erred in not accepting the district court's evaluation, the Supreme Court indicated that it was not troubled by the district court's analysis even though that analysis was predicated on the view that the totality of fact and expression was protectible. Unlike the district court, however, the Court cited instances of quotations by Navasky that constituted "among the most powerful passages in those chapters." 89 In light of the Court's general
81 Id.
82 Id.
83 Id.

84 See id. at 2226-30. The Court, relying almost exclusively on statements in various treatises, concluded that "it has never been seriously disputed" that the fair use defense is severely limited when the work sought to be used is not published. Id. at 2226.

so See id. at 2230 . The right of first publication has by virtue of the Court's opinion now been imbued with both a statutory and a constitutional aspect.

${ }^{88}$ Id. at 2233 (quoting 557 F. Supp. at 1072).

87 Id.

88 See 557 F. Supp. at 1072 \& n.10.

82 $105 \mathrm{~S}$. C. at 2233. 
reluctance to act as a factfinder, ${ }^{90}$ it is unlikely that the Court was making its own factual finding in addition to the district court's finding. Rather, the Court appears to have attempted to reinforce the district court's conclusion. This reading is consistent with the Court's own view that in fair use analysis an appellate court can evaluate fair use as a factual matter only if the trial court "has found facts sufficient to evaluate each of the statutory factors."

The final portion of the fair use inquiry focused on the economic effect of the use. Again, the Court adhered to the district court's finding that The Nation's use caused Time to cancel its plan to publish the excerpts. In the Court's view, the publishers had "established a prima facie case of actual damage that [The Nation] failed to rebut."92 Navasky's article also infringed the publishers' right to create or license derivative works based on the original. In this case, the derivative work in question would have been a serialization of the memoirs.

The Court construed the Second Circuit's first amendment analysis as requiring that the extant first amendment concerns in the dissemination of information of public interest should widen the scope of fair use. $^{93}$ The Court rejected this analysis because it would, if accepted, (1949).

so See, e.g., Graver Tank \& Mfg. Co. v. Linde Air Prods. Co., 336 U.S. 271, 275

105 S. Ct. at 2231.

${ }^{82}$ Id. at 2234. Again, the Court's reliance on the district court's finding at least suggests that the Court accepted the district court's view that the totality of fact and expression was protectible. The Court stated that "[a]ny publication of material from chapters 1 and 3 would permit Time to renegotiate its final payment." Id. The Court concluded that "once a copyrightholder establishes with reasonable probability the existence of a causal connection between the infringement and a loss of revenue, the burden properly shifts to the infringer to show that this damage would have occurred had there been no taking of copyrighted expression." Id. The difficulty with the Court's position is that although the agreement between Harper \& Row and Time provided for renegotiation if any material on the Nixon resignation or pardon were printed before Time's serialization, see Petition for a Writ of Certiorari to the United States Court of Appeals for the Second Circuit at G19-C20, The Nation, that provision established only a term of the private licensing agreement, and was not sufficient to serve as the criterion to determine whether any prepublication constituted infringement under the copyright statute. Similarly, the Court's characterization of Navasky's use, based on the verbatim quotations, as one that "commingles infringing and noninfringing elements," $i d$., begs the question whether Navasky's use was an infringement.

${ }_{83}$ As was demonstrated earlier, this interpretation is incorrect. The Second Circuit relied on the first amendment concerns primarily to inform its understanding of the issues of copyrightability, not fair use. See supra text accompanying notes 44-52 \& 62 67.

In addition, the Court attributed a first amendment argument to The Nation on the basis of its assertions that the manner in which Ford expressed himself was as newsworthy as the factual information. This assertion was made in the context of The Nation's argument concerning the amount and substantiality of the material used. See Brief for Appellant at 38-39, The Nation. The Nation argued that the case presented no first amendment issue besides the one that informed the idea/expression distinction. 
"effectively destroy any expectation of copyright protection in the work of a public figure." in dissemination is accommodated solely by the idea/expression dichotomy, which permits "free communication of facts while still protecting an author's expression." "98 Further, Navasky did not "assert any actual necessity" for the use of Ford's expression. ${ }^{96}$ Finally, the Court acknowledged that although copyright holders could not use their monopoly to suppress facts, the first amendment protected the right not to speak publicly, especially when the copyrighted material involved had not been published. ${ }^{97}$

In dissent, Justice Brennan, joined by Justices White and Marshall, argued that the copyright interest in promoting science and the

See id. at 41-45.

94105 S. Ct. at 2229.

9s Id. (quoting The Nation, 723 F.2d at 203).

${ }^{96} I d$. at 2229. This contention is at odds with the Court's recognition that some of the material used by Navasky was "arguably necessary adequately to convey the facts." Id. at 2232.

${ }^{97}$ A New York Times editorial characterized The Nation as a decision upholding "the right of the reader to learn important public facts in timely fashion vs. the property right of the writer to individual thought and expression." N.Y. Times, May 22, 1985 , at A26, col. 1. The editorial stated further that the "Supreme Court upheld the writer's right without infringing on that of the reader." $I d$. Such a conclusion seems to be drawn from the perception that the decision was a narrow one that turned on the question-"Did the magazine use too much of Gerald Ford's literary originality, too many of his own words?"- and held that "authors, whether public figures or not, may copyright their own way of saying things but not the facts they convey." Id.

The editorial also expressed concern that "[a]ll too frequently, persons in brief authority hoard documents that are not their intellectual property" so that they may "write history's first version." Id. The editorial noted that this practice is also an infringement-perhaps not one of copyright, but of "public rights." See id.

One month later, Roger L. Zissu, counsel to Harper \& Row, responded to the New York Times' assertions. See N.Y. Times, June 22, 1985, at A26, col. 1. Zissu contested the statement contrasting the right of the reader and the writer's property right. He stated that copyright should not be seen merely as a property right that conflicts with the public's access to information. Instead, "copyright works together with the First Amendment in fostering the creation and dissemination of works that are the source of important public information." Id.

Zissu also took issue with what he described as the suggestion that Ford hoarded documents in order to write this history for the first time. He then asserted that "it was undisputed that President Ford's memoirs were a series of recollections that were not document-based," and that the documents referred to in the book were available prior to its publication. Id.

Floyd Abrams, counsel for The Nation, responded to Zissu's letter, also on the New York Times' editorial page. See N.Y. Times, July 3, 1985, at A20, col. 5. Abrams pointed out that the dissent viewed the majority opinion "as permitting private monopolization of information at the expense of the robust public debate the First Amendment was intended to protect." Id. He also noted "the willingness of book publishers, who generally wrap themselves in the protective covering of the First Amendment, to sacrifice the public interest ... in return for a $\$ 12,500$ recovery." Id. Abrams concluded with a warning that "[b]ook publishers . . . should know better." Id. 
useful arts, and the first amendment interest in broad dissemination of factual information, were both "ill served" by the majority's "constricted reading of the fair use doctrine."18

\section{B. The Basic Features of Copyright Law That Explain the Divergent Approaches in The Nation}

The obvious tension present among the different approaches taken in these three opinions can be traced to uncertainty surrounding the interpretation and application of various features of copyright doctrine relevant to factual works. Each feature plays some role in one or more of the opinions in The Nation.

One overriding concern that pervades this Article's examination of copyright protection for factual works is that courts appear to treat the doctrines of copyrightability, infringement, and fair use as interchangeable doctrines that equally well "cut back upon the reach of the copyright monopoly in order that there can be social progress through the expansion of the fund of human knowledge."'99 In The Nation, al-

es See $105 \mathrm{~S}$. Ct. at 2240 . The thrust of the dissent was that the majority wrongly decided the fair use issue and wrongly ignored the copyrightability issue. The dissent argued that the purpose and character of the article was "news" and was not affected by commercial considerations, Navasky's intent to "scoop" Time magazine, or any bad faith on Navasky's part. See id. at 2246-47. News articles are generally written for profit; therefore, Navasky had the right to "scoop" the unprotectible information, and thus could hardly be characterized as acting in bad faith in using minimal literal expression. See id.

Addressing the nature of the copyrighted work, the dissent again identified factors militating in favor of fair use. See id. at 2248-50. A factual work is much more conducive to productive use, and the fact that it is unpublished does not affect this aspect of the nature of the factual work. Ford had no intention of keeping the memoirs confidential, and any other interest that he had that was protected by the right of first publication was an economic interest and should not affect fair use analysis of the nature of the work.

With respect to the amount and substantiality of the infringed work, the dissent pointed out that the majority relied on the district court finding, which was predicated on the unacceptable "totality" analysis. See id. at 2251. The dissent acknowledged that The Nation appropriated expression "among the most poignant in the Ford manuscript," and that this weighed against Navasky more seriously than any other aspect of the fair use analysis. See id. at 2253. The dissent, however, found it "difficult to say that the use of the ... quotations was gratuitous in relation to the news reporting purpose." Id. at 2252.

Finally, the dissent maintained that the publishers had not proven any economic detriment because it was possible that what actually caused Time to cancel its publication was Navasky's use of unprotectible information. See id. at 2252.

The dissent also discussed issues of copyrightability. Echoing the principle that ideas and facts could not be copyrighted, the dissent went on to find that there was no substantial tracking of Ford's expression in either language or structure of presentation that would constitute infringement. See id. at 2253. As discussed later, this portion of the dissent confused copyrightability and infringement issues.

9o Gorman, supra note 3, at 596. 
though the district court and court of appeals relied on doctrines of copyrightability and infringement in addition to fair use to reach their respective results, the Supreme Court ostensibly sidestepped these issues and based its decision solely on fair use considerations. The failure to keep separate the doctrines of copyrightability, infringement, and fair use means that the distinctly different concerns that underlie these various copyright doctrines are blended into an incomprehensible hodgepodge that makes it nearly impossible to understand what doctrinal considerations are at stake in any given case. ${ }^{100}$

The doctrine of copyrightability delimits which works, or parts of works, are eligible for copyright protection. Several issues of copyrightability arise in the examination of factual works. First, it is an axiom of copyright law that copyright protection does not extend to facts. ${ }^{101}$ This prohibition, which is now embodied in the copyright statute, ${ }^{102}$ has its origin in several sources. Copyright represents a temporally ${ }^{\mathbf{1 0 3}}$ and substantively" limited "utilitarian" right that is granted not as a recognition of any "natural right" of authors to the fruits of their intellectual or artistic labors, ${ }^{105}$ but as an incentive to authors for the purpose of

100 For example, in Consumers Union of United States, Inc. v. General Signal Corp., 724 F.2d 1044, 1049-50 (2d Cir. 1983), cert. denied, 105.S. Ct. 100 (1984), the court of appeals rested a portion of its fair use analysis on Morrissey v. Procter \& Gamble Co., 379 F.2d 675 (1st Cir. 1967), which involved an issue of copyrightability.

101 See, e.g., The Nation, 105 S. Ct. at 2229; Miller v. Universal City Studios, 650 F.2d 1365, 1368 (5th Cir. 1981); Hoehling v. Universal City Studios, 618 F.2d 972, 974 (2d Cir.), cert. denied, 449 U.S. 841 (1980); Oxford Book Co. v. College Entrance Book Co., 98 F.2d 688, 691 (2d Cir. 1938).

10217 U.S.C. $\$ 102$ (b) (1982) provides that "[i]n no case does copyright protection for an original work of authorship extend to any idea, procedure, process, system, method of operation, concept, principle, or discovery, regardless of the form in which it is described, explained, illustrated, or embodied in such work."

103 Under the 1976 Copyright Act, Pub. L. No. 94-553, 90 Stat. 2541 (codified as amended at 17 U.S.C. $\S \S 101-810$ (1982)), which became effective on January 1, 1978 , copyright protection for works created on or after that date "endures for a term consisting of the life of the author and fifty years after the author's death." 17 U.S.C. $\S 302(\mathrm{a})$; see also id. $\S 303$ (dealing with the duration of protection in works created but not published or copyrighted before January 1, 1978); id. $\S 304$ (dealing with the duration of copyright for works in which copyright protection was originally obtained under the prior statute). Under the prior statute, copyright protection endured for "twenty-eight years from the date of first publication" with the possibility of an additional twenty-eight year term. Act of Mar. 4, 1909, ch. 320, § 23, 35 Stat. 1075, 1080 (current version at 17 U.S.C. $\$ 304$ (1982)).

104 The subject matter of copyright protection is limited by provisions contained in 17 U.S.C. $\S \S 102-105$ (1982), and the exclusive rights granted by copyright are limited by 17 U.S.C. $\S \S 107-118$ (1982).

${ }^{103}$ In some European countries and in those countries that adhere to the Berne Convention, there exists the doctrine of droit moral, or "moral rights," which embodies the notion that artistic or literary works reflect the personality of the author and are not granted merely as an incentive. See 2 M. NIMMER, supra note 73, at $\S 8.21[A]$. Some states have adopted various forms of these moral right notions. See Francione, 
promoting "the Progress of Science and the Useful Arts"108 through the production and dissemination of literary works. As Professor Nimmer has noted, copyright protection "is granted for the very reason that it may persuade authors to make their ideas freely accessible to the public so that they may be used for the intellectual advancement of mankind." ${ }^{107}$ As a consequence of this goal of generating and providing accessibility to ideas, the limited monopoly provided by copyright extends only to the expression of ideas, and not to the ideas themselves. ${ }^{108}$

The concern for preventing a monopoly of ideas was extended under early English case law to include facts and information. ${ }^{109}$ Permitting exclusive control over facts and information would disserve the public interest that copyright was designed to promote as much as would granting monopoly protection of the ideas contained in protected expression. Further, the distinction between ideas or facts and expression reflects a concern that to grant copyright protection beyond expression would create a conflict with first amendment values. The Supreme Court in The Nation explicitly recognized that the idea/expression dis-

The California Art Preservation Act and Federal Preemption by the 1976 Copyright Act-Equivalence and Actual Conflict, 31 Copyrighr L. SYMP. (ASCAP) 105 (1984).

Professor Denicola argues that "[n]otions of a natural right to the fruits of one's labor, and of the injustice of the enrichment that falls to the taker are as much a part of copyright as the careful balancing of incentive and dissemination." Denicola, supra note 22 , at $519-20$.

${ }^{108}$ U.S. CONST. art. $1, \S 8, \mathrm{cl} .8$, provides that "Congress shall have the Power ... [t]o promote the Progress of Science and the useful Arts, by securing for limited Times to Authors and Inventors the exclusive Right to their respective Writings and Discoveries."

${ }_{107} 3 \mathrm{M}$. NIMMER, supra note 73, at $\S 13.03$ [A][1]. Not all scholars accept the "incentive" rationale of copyright protection. Compare Breyer, The Uneasy Case for Copyright: A Study of Copyright in Books, Photocopies, and Computer Programs, 84 HARV. L. REv. 281, 285-86 (1970) (arguing that it is unlikely that an author's "reward" guaranteed under copyright law is needed as an incentive or is more "just" than the reward that would result without such protection) and Breyer, Copyright: $A R e$ joinder, 20 UCLA L. REv. 75, 75 (1972) (maintaining that the "noneconomic benefits of a copyright system . . . are in themselves insufficient to support the principle of protection," and that the economic basis for copyright is unnecessary to "secure production") with Tyerman, The Economic Rationale for Copyright Protection for Published Books: A Reply to Professor Breyer, 18 UCLA L. REv. 1100, 1103 (1971) (arguing that the present copyright system is a proven "system for ensuring both that authors find it intellectually and financially profitable to write, and that the American publishing industry is capable of producing a broad spectrum of book titles").

108 See, e.g., Mazer v. Stein, 347 U.S. 201, 217 (1954). The idea/expression distinction is now embodied in the copyright statute. See 17 U.S.C. $\$ 102(b)(1982)$, reprinted supra note 102.

109 See Matthewson v. Stockdale, 33 Eng. Rep. 103, 105 (Ch. 1806). In Matthewson, Lord Erskine stated that "no man can monopolize . . . the events of the world." Id.; see also Triangle Publications v. Sports Eye, Inc., 415 F. Supp. 682, 685 n.9 (E.D. $\mathrm{Pa}$. 1976) ("For the purposes of copyright infringement, data and ideas are treated as equivalents."). 
tinction " strike[s] a definitional balance between the First Amendment and the Copyright Act by permitting free communication of facts while still protecting an author's expression." "110

The prohibition on copyright protection for facts is also related to the constitutional and statutory requirement that copyright protection extend only to original works of authorship. ${ }^{111}$ The requirement of originality is ostensibly not satisfied by the presentation of fact, nor even by an interpretation of fact, which is itself at most a verifiable or falsifiable hypothesis about a fact or set of facts, and which, if verified, represents yet another fact or set of facts. ${ }^{112}$

Although it is clear that copyright protection does not extend to facts or ideas, but only to their expression, it is far from clear where to draw the dividing line. The distinction between ideas and expression in any case is difficult to determine, and, as Learned Hand observed, "no principle can be stated as to when an imitator has gone beyond copying the 'idea' and has borrowed its 'expression.' Decisions must therefore inevitably be ad hoc."11s This difficulty is particularly troublesome

110105 S. Ct. at 2229 (quoting The Nation, 723 F.2d at 203). For articles that explore this issue in more depth, see infra note 148.

111 The constitutional requirement finds its origin in the copyright clause, which allows copyright protection to be extended to "Authors." See U.S. CoNST. art. 1, § 8, cl. 8. The Supreme Court has defined an "author" as "he to whom anything owes its origin; originator; maker; one who completes a work of science or literature." "BurrowGiles Lithographic Co. v. Sarony, 111 U.S. 53, 58 (1884) (quoting WorCESTER's ACADEMIC DictionaRy (1881)). The "originality" requirement "means little more than a prohibition of actual copying." " Alfred Bell \& Co. v. Catalda Fine Arts, Inc., 191 F.2d 99, 103 (2d Cir. 1951) (quoting Hoague-Sprague Corp. v. Frank C. Meyer Co., 31 F.2d 583, 586 (E.D.N.Y. 1929)). The 1976 Copyright Act provides that "[c]opyright protection subsists . . . in original works of authorship." 17 U.S.C. $\S 102$ (a) (1982). The copyright statute also provides protection to derivative works, see id. $\S 103$, which are works "based upon one or more preexisting works." Id. $\S 101$. Some courts have held that the standard for the originality of derivative works is higher than for ordinary works. See, e.g., Gracen v. Bradford Exch., 698 F.2d 300, 305 (7th Cir. 1983).

112 See infra note 241.

113 Peter Pan Fabrics, Inc. v. Martin Weiner Corp., 274 F.2d 487, 489 (2d Cir. 1960). In Nichols v. Universal Pictures Corp., 45 F.2d 119 (2d Cir. 1930), cert. denied, 282 U.S. 902 (1931), Judge Hand articulated the now famous "abstractions test" for helping to draw the line between idea and expression:

Upon any work, and especially upon a play, a great number of patterns of increasing generality will fit equally well, as more and more of the incident is left out. The last may perhaps be no more than the most general statement of what the play is about, and at times might consist only of its title; but there is a point in this series of abstractions where they are no longer protected, since otherwise the playwright could prevent the use of his "ideas" to which, apart from their expression, his property is never extended.

Id. at 121.

Professor Chafee maintained that protectible expression covers the "pattern" of the 
when factual works are involved because there are considerable uncertainties about what constitutes a "fact" and what constitutes "factual expression."

The tension over how to apply this first axiom-that copyright protection does not extend to facts-surfaces most clearly in the conflict between the district court and court of appeals opinions in The Nation. Although both courts asserted that facts are not copyrightable, the district court retreated from that position in its view that noncopyrightable facts contained in the memoirs received derivative copyright protection by being merged into a copyrightable totality of facts and Ford's reflections and revelations about those facts. ${ }^{114}$ It was this totality that the district court found to be infringed by the subsequent use. The Supreme Court attempted to sidestep this issue by focusing solely on the verbatim quotations; nevertheless, the Court's attempt failed because its analysis relied on the district court's findings, which incorporated the totality approach adopted by that court.

A second axiom of copyrightability that has a direct and confounding impact on the analysis of factual works is that copyright protection may extend only to a "writing." 115 Although some minimal "intellectual labor" is required for a "writing," copyright protection

work in terms of its "sequence of events and the development of the interplay of the characters." Chafee, Reflections on the Law of Copyright (pt. 1), 45 Colum. L. REv. 503, 513-14 (1945).

114 For example, the district court in The Nation held that Ford's "revelations as to his state of mind," 557 F. Supp. at 1073, were factual expressions, and thus copyrightable. See id. at 1072. The court of appeals reversed the trial court but did not directly resolve the issue of the copyrightability of Ford's "revelations." See 723 F.2d at 204-05. Nevertheless, the court of appeals noted:

[T]hough it is true these responses did originate with Ford and might be accurately described as his unique perspective, it seems to defy common sense to declare that the "states of mind" which play a role in the crucial political decisions of public officials are any less "fact" than any act which such an official may choose or not choose to undertake.

Id. (footnote omitted).

115 See U.S. CoNST. art. $1, \S 8, \mathrm{cl}$. 8. The requirement of a "writing" has been interpreted to include "any physical rendering of the fruits of creative intellectual or aesthetic labor." Goldstein v. California, 412 U.S. 546, 561 (1973). Congress has consistently recognized the broad area in which it may act by amending the copyright statute to extend to more categories of works. See id. at $562 \mathrm{n.17}$; see also Bleistein v. Donaldson Lithographing Co., 188 U.S. 239, 243 (1903) (upholding copyrightability of circus poster illustration); Burrow-Giles Lithographic Co. v. Sarony, 111 U.S. 53 (1884) (upholding copyrightability of photograph).

${ }_{110}$ The Trade-Mark Cases, 100 U.S. 82, 94 (1879). There is some confusion as to how the requirement of "intellectual labor" relates to "originality" and "authors." See supra note 111. In the Trade-Mark Cases, the Supreme Court stated:

And while the word writings may be liberally construed, as it has been, to include original designs for engravings, prints, \&c., it is only such as are original, and are founded in the creative powers of the mind. The writ- 
extends only to works "fixed in any tangible medium of expression."117 As a result, copyright protection cannot extend to the labor per se that goes into a work. ${ }^{118}$ In the case of factual works, unlike that of fictional works, the primary contribution of the author is the aggregation of data that are subsequently compiled or arranged, or research that is eventually embodied in the nonfiction narrative, and not the protectible expression of the data or the research. Although protection of expression in works of fiction may reasonably suffice to provide the incentive to authors necessary for the production and dissemination of works of fiction, protection of only bare expression in a nonfiction work appears to provide insufficient incentives for production of the work in the first instance.

As a result of this apparent deficiency in protection, some courts have struggled to provide protection that is consistent with both the constitutional protection of "writings" and the axiom that facts are per se noncopyrightable, and also provides some protection for the labor embodied in a nonfiction work. This protection has most frequently taken the form of a requirement, injected at various points in an in-

ings which are to be protected are the fruits of intellectual labor, embodied in the form of books, prints, engravings, and the like.

100 U.S. at 94 . The quotation suggests that originality may be linked to the requirement of intellectual labor. Professor Nimmer argues that

[i]t is important to distinguish between the requirement of originality and the requirement of intellectual labor .... The doctrine of originality stems from the Copyright Clause's use of the term "authors" and refers to independent creation. Intellectual labor, on the other hand, suggests an absolute standard, albeit a highly minimal one, of creativity.

$1 \mathrm{M}$. Nimmer, supra note 73, at $\S 1.08[$ C][1]. At another point, Professor Nimmer states that "[i]t is of only semantic significance whether originality is defined as embodying such creativity or whether such creativity is regarded as a necessary adjunct to originality. However, a greater clarity of expression is perhaps achieved by regarding originality and creativity as separate elements." Id. \& 2.01[B].

Professor Denicola argues that originality and intellectual labor should be regarded as different requirements. See Denicola, supra note 22, at 521-22. He states that Professor Nimmer treats creativity as "part of the concept . . . of originality." Id. at 521 n.28. Although Professor Nimmer seems to present a "stronger" and "weaker" theory of the separation of originality from intellectual labor, he does separate them.

It should also be noted that Professor Nimmer views the intellectual labor requirement, part of the concept of "writings," as providing an additional ground for the prohibition on extending copyright to facts. See $1 \mathrm{M}$. NMMER, supra note 73 , at $\S 1.08[\mathrm{C}][1]$.

11717 U.S.C. § 102(a) (1982) (emphasis added). The Act also provides that a "work consisting of sounds, images, or both, that are being transmitted, is 'fixed' for purposes of this title if a fixation of the work is being made simultaneously with its transmission." Id. $\S 101$.

${ }_{118}$ See 1 M. NIMMER, supra note 73 , at $\S 3.04$. But see Denicola, supra note 22, at 530 (arguing that with nonfictional works "[t]he effort of authorship can be effectively encouraged and rewarded only by linking the existence and extent of protection to the total labor of production"). 
fringement analysis, that a subsequent author of a nonfiction work engage in some "independent research" in preparing the work. ${ }^{119}$ For example, in the dissent to the court of appeals opinion in The Nation, Judge Meskill found The Nation's use of the Ford memoirs objectionable in part because it did not include original material in addition to its reporting of the contents of the actual memoirs. ${ }^{120}$ Justice Brennan's dissent in The Nation noted that the majority's fair use analysis may have reflected an attempt to compensate for the fruit of Ford's labor reflected in his preparation of the memoirs. ${ }^{121}$

Once copyrightability is established, the next issue is whether the copyright was infringed by the subsequent use of the work. The standard for copyright infringement of factual works is unsettled. Generally, the plaintiff in an infringement action must show that the plaintiff owns the copyright and that the defendant copied the work. ${ }^{\mathbf{1 2 2}}$ Because direct evidence of the defendant's copying is rarely available, the plaintiff may show copying indirectly by proving that the defendant had access to the plaintiff's work and that the defendant's work is substantially similar in whole or part to the plaintiff's work. ${ }^{123} \mathrm{~A}$ finding of substantial similarity may be predicated only on similarities between the defendant's work and the plaintiff's protectible expression. But if the facts contained in factual works are themselves not protectible, then it may be argued that the concept of "expression" in factual works must in some sense be limited. ${ }^{124}$ After all, two biographies of a historical figure are bound to be more similar than two novels expressing a common theme. Further, although the determination of whether substantial similarity exists is generally an issue of fact, courts appear con-

119 See, e.g., Meredith Corp. v. Harper \& Row, Publishers, 378 F. Supp. 686, 690 (S.D.N.Y.), affd, 500 F.2d 1221 (2d Gir. 1974).

${ }^{120}$ See 723 F.2d at 213-14 (Meskill, J., dissenting).

121 See 105 S. Ct. at 2246 (Brennan, J., dissenting).

122 See, e.g., Sid \& Marty Krofft Television Prods. v. McDonald's Corp., 562 F.2d 1157, 1162 (9th Cir. 1977); Reyher v. Children's Television Workshop, 533 F.2d 87, 90 (2d Cir.), cert. denied, 429 U.S. 980 (1976); Arnstein v. Porter, 154 F.2d 464, 468 (2d Cir. 1946).

${ }_{123}$ See, e.g., Reyher v. Children's Television Workshop, 533 F.2d 87, 90 (2d Cir.), cert. denied, 429 U.S. 980 (1976).

${ }_{124}$ Cf. Lauratex Textile Corp. v. Gitations Fabrics Corp., 328 F. Supp. 554, 555 (S.D.N.Y. 1971) (holding that because the basic design for a textile pattern was not original, the plaintiff was entitled to copyright protection only for what it had added to the work); Millworth Converting Corp. v. Slifka, 276 F.2d 443, 445 (2d Cir. 1960) ("D]efendants are 'entitled to use, not only all that had gone before, but even the plaintiffs' contribution itself, if they drew from it only the more general patterns; that is, if they kept clear of its "expression." ") (quoting Sheldon v. Metro-Goldwyn Pictures Corp., 81 F.2d 49, 54 (2d Cir.), cert. denied, 298 U.S. 669 (1936), quoted in Concord Fabrics, Inc. v. Generation Mills Inc., 328 F. Supp. 1030, 1032 (S.D.N.Y. 1971)). 
fused about the manner in which the unprotected status of facts should be considered in making this determination. ${ }^{125}$ Confusion concerning this third feature of copyright law is illustrated by conflict between the district court and court of appeals in The Nation on what constitutes protectible "expression" when factual works are involved. The court of appeals held that small variations in paraphrasing of factual material could obviate a finding of infringement, ${ }^{\mathbf{1 2 6}}$ whereas the district court viewed the paraphrasing as prohibited copying. ${ }^{127}$

Finally, if there has been an infringement, the subsequent use may nevertheless be protected as a "fair use." The fair use doctrine has been characterized as "the most troublesome in the whole law of copyright,"128 and there are considerable difficulties involved in applying the doctrine to factual works. Fair use, formerly a judicially created doctrine and now embodied in the copyright statute, ${ }^{129}$ is a "privilege in others than the owner of a copyright to use the copyrighted material in a reasonable manner without his consent, notwithstanding the monopoly granted to the owner by the copyright." 130 The application of the doctrine of fair use to any particular case is completely dependent on the facts and circumstances involved, and although there are specific criteria that courts are directed to apply, ${ }^{131}$ courts often apply these criteria inconsistently and incomprehensibly. In the context of factual works, there is particular confusion as courts attempt to weigh as a fair use factor the "public interest" involved in the dissemination of factual works, or the "necessity" of a particular use-at least in part to accommodate first amendment concerns that arise when a copyright prohibits the expression of a subsequent author. ${ }^{132}$ For example, the court of appeals in The Nation held that interpretation of the fair use provision required consideration of the first amendment concerns that have informed fair use analysis. ${ }^{133}$ In reversing that decision, the Supreme

125 Compare Sheldon v. Metro-Goldwyn Pictures Corp., 81 F.2d 49, 54-55 (2d Cir.) (refusing to disqualify noncopyrightable elements from determination of substantial similarity), cert. denied, 298 U.S. 669 (1936) with Hoehling v. Universal City Studios, 618 F.2d 972, 977 (2d Cir.) (affirming a grant of summary judgment because all alleged substantial similarity was related to noncopyrightable elements in the plaintiff's work), cert. denied, 449 U.S. 841 (1980).

128 See 723 F.2d at 203.

127 See 557 F. Supp. at 1073.

128 Dellar v. Samuel Goldwyn, Inc., 104 F.2d 661, 662 (2d Cir. 1939).

${ }^{120}$ See 17 U.S.C. $\$ 107$ (1982), reprinted supra note 13.

$130 \mathrm{H}$. Ball, The Law of Copyright and Literary Property $\S 125$, at 260 (1944).

131 See 17 U.S.C. § 107 (1982), reprinted supra note 13.

132 See, e.g., Rosemont Enters. v. Random House, Inc., 366 F.2d 303, 307 (2d Cir. 1966), cert. denied, 385 U.S. 1009 (1967).

133 See 723 F.2d at 208. 
Court explicitly rejected the Second Circuit's inclusion of first amendment considerations in the fair use context, and applied a much more restricted fair use doctrine. ${ }^{134}$

\section{TRUnCation of FaIR USE IN The Nation}

Rather than addressing the difficult issues of copyrightability and infringement of factual works, some courts ${ }^{135}$ and copyright scholars ${ }^{136}$ have generally argued for broad protection of factual works and then have sought to rely on the fair use doctrine as a means of resolving any perceived difficulties caused by the tension that exists between the first amendment and the copyright purpose of protecting an author's expression. In this section, I argue that even if fair use were ever a solution to the problem raised by broad protection of factual works, the Supreme Court's opinion in The Nation appears to have diminished significantly the utility of that solution. ${ }^{137}$

194 See 105 S. Ct. at 2229-35.

13s See, e.g., Wainwright Sec. Inc. v. Wall St. Transcript Corp., 558 F.2d 91, 95 (2d Cir. 1977), cert. denied, 434 U.S. 1014 (1978) ("Conflicts between interests protected by the first amendment and the copyright laws thus far have been resolved by application of the fair use doctrine.") (citing Walt Disney Prods. v. Air Pirates, 345 F. Supp. 108 (N.D. Cal. 1972), rev'd in part, 581 F.2d 751 (9th Cir. 1978), cert. denied, 439 U.S. 1132 (1979)).

136 Professor Gorman argues that factual works should be copyrightable, and that copyright protection can then be controlled through infringement and fair use. $\mathrm{He}$ views infringement and fair use as largely interchangeable tools for balancing relevant considerations, including the inseparability of fact and expression. See Gorman, supra note 3, at 596. Insofar as the first amendment is concerned, Professor Gorman takes issue with the position that any separate defense is necessary given the idea/expression distinction and "the flexibility inherent in the fair use doctrine." Id. at 597.

Professor Denicola argues for copyright protection of collections of data and assemblages of facts, and finds no threat to copyright goals or the first amendment because "[e]ven more substantial takings [than those permitted under the substantial taking standard of infringement] may be permitted under the fair use doctrine." Denicola, supra note 22 , at 541 .

Professor Ginsburg argues that the use of "factual interpretations and other factdependent expression," Ginsburg, supra note 22 , at 671 , should not be evaluated at the substantial similarity stage, but should be a part of the fair use inquiry. See id. at 67073.

${ }^{137}$ In this section, I will address only those aspects of the Court's decision that will most likely affect directly the fair use analysis of factual works, especially nonfiction narratives. Nevertheless, one rather troublesome doctrine that affects all copyrightable works and that does deserve some treatment is the Court's "presumption" in The Nation against the fair use of unpublished works: "Under ordinary circumstances, the author's right to control the first public appearance of his undisseminated expression will outweigh a claim of fair use." $105 \mathrm{~S}$. Ct. at 2228. This truncation of fair use protection for all authors represents a version of the "totality" approach in that the analysis does not distinguish between those portions of the unpublished materials that are copyrightable and those that are not. To the extent that all of the material is presumed not to be subject to fair use, material that is per se noncopyrightable becomes protected. 
The first way the Court has truncated the fair use doctrine as applied to factual works results from the Court's collapsing of fair use, copyrightability, and infringement issues. Because the Court did not keep these three doctrines distinct in The Nation, it has opened the door to excessive protection for factual works. ${ }^{138}$ For example, although the Court purported not to address the legitimacy of the totality approach, the Court used the district court's findings in its fair use analysis even though these findings were predicated on an explicit totality approach. ${ }^{139}$ In addition, the Court's fair use analysis confusingly blended copyrightability, infringement, and fair use concerns. ${ }^{\mathbf{1 4 0}}$

The reason that a fair use analysis incorporating copyrightability and infringement issues truncates protection for subsequent users of

Although the majority argued that this presumption is embodied in the common law and scholarly commentary, the dissent correctly countered with the observation that "[t]he common law did not set up the monolithic barrier to prepublication fair use that the Court wishes it did." Id. at 2249 n.19 (Brennan, J., dissenting). There is simply no substantial authority that supports the Court's presumption. Indeed, there is authority to the contrary. See, e.g., Estate of Hemingway v. Random House, Inc., 53 Misc. 2d 462, 466-67, 279 N.Y.S.2d 51, $57-58$ (Sup. Ct.), affd, 29 A.D.2d 633, 285 N.Y.S.2d 568 (App. Div. 1967), aff'd on other grounds, 23 N.Y.2d 341, 244 N.E.2d 250, 296 N.Y.S.2d 771 (1968). The Court correctly cited Professor Nimmer for the proposition that "unpublished nature of a work is "[a] key, though not necessarily determinative, factor" " tending to negate the defense of fair use. $105 \mathrm{~S}$. Ct. at 2227-28 (quoting $3 \mathrm{M}$. NimMER, supra note 73, at $\S 13.05$ n.2). However, the Court neglected to note Professor Nimmer's additional qualification that "the scope of the fair use doctrine is considerably narrower with respect to unpublished works which are held confidential by their copyright owners." $3 \mathrm{M}$. NIMMER, supra note 73, at $\S 13.05$ [A][2].

In addition, the Court's presumption ignores the issue of how to balance "the exclusive rights of a copyright holder with the public's interest in dissemination of information affecting areas of universal concern," which is the function of the fair use doctrine. Wainwright Sec. Inc. v. Wall St. Transcript Corp., 558 F.2d 91, 94 (2d Cir. 1977), cert. denied, 434 U.S. 1014 (1978). If, as the Court suggested by its presumption, the copyright owner's unpublished work is deemed virtually immune from the doctrine of fair use, the public interest is ignored, and the copyright holder's interest is the only one considered.

Further, the Court's presumption is inconsistent with the copyright statute. The copyright holder's exclusive right to distribute copies of the work, see 17 U.S.C. $\S 106(3)$ (1982), is explicitly made subject to the fair use provisions. See id. $\S 107$ (1982), reprinted supra note 13 . The Court referred to some inconclusive and ambiguous legislative history and concluded that Congress intended only to restate in section 107 the common-law understanding of fair use, and that the common law recognized the pivotal importance of the unpublished status of the work. See $105 \mathrm{~S}$. Ct. at 2227. Yet, inexplicably, the Court failed to recognize that at common law there was no absolute rule about the fair use of unpublished work.

Finally, the 1976 Copyright Act provides that copyright protection begins at the moment the work is "fixed in any tangible medium of expression." 17 U.S.C. $§ 102(a)$ (1982). Congress has eliminated the importance of "publication." There is simply no reason not to read the right of first distribution as governed by the fair use provision.

${ }^{138}$ See infra notes 271-81 and accompanying text.

139 See supra text accompanying notes 86-91.

${ }^{140}$ See infra text following note 271. 
factual works is that fair use analysis is an ad hoc procedure that "cannot be determined by resort to any arbitrary rules or fixed criteria."141 Although the 1976 Copyright Act suggests criteria to be considered in determining fair use, ${ }^{\mathbf{1 4 2}}$ it is clear that Congress did not intend to alter the doctrine's character as an "equitable rule of reason."143 Determined according to myriad criteria, fair use is generally considered a question of fact for which factfinders balance the equities subject to appellate review under the "clearly erroneous" standard. ${ }^{144}$ The party seeking to rely on the fair use doctrine "bears the burden of production and persuasion to show that the [defense] is applicable."145 It is vitally important that issues having to do with copyrightability and infringement are not "balanced" in the context of the scheme of competing equities established by the fair use doctrine.

The second truncation of the fair use doctrine in the Court's opinion in The Nation occurs as a result of the Court's rejection of the fair use analyses adopted in Rosemont Enterprises $v$. Random House, Inc., ${ }^{148}$ and Time Inc. v. Bernard Geis Associates, ${ }^{147}$ both of which incorporated first amendment concerns in the fair use context. ${ }^{148}$ In

141 Meeropol v. Nizer, 560 F.2d 1061, 1068 (2d Cir. 1977), cert. denied, 434 U.S. 1013 (1978), quoted in Iowa State Univ. Research Found. v. American Broadcasting Cos., 621 F.2d 57, 60 (2d Cir. 1980).

142 See 17 U.S.C. \& 107 (1982), reprinted supra note 13.

${ }^{143}$ Sony Corp. v. Universal Gity Studios, 464 U.S. 417, 448 n.31 (1984) (discussing the legislative history of the fair use provision).

144 See, e.g., M.C.A., Inc. v. Wilson, 677 F.2d 180, 183 (2d Cir. 1981); Triangle Publications v. Knight-Ridder Newspapers, 626 F.2d 1171, 1175 (5th Cir. 1980). In The Nation, the Supreme Court characterized fair use as a mixed question of law and fact on the basis of a footnote in a recent opinion. See $105 \mathrm{~S}$. Ct. at 2231 (citing Pacific \& S. Co. v. Duncan, 744 F.2d 1490, 1495 n.8 (11th Cir. 1984), cert. denied, 105 S. Ct. 1867 (1985)). There is nothing in the Court's opinion in The Nation suggesting that the Court viewed the standard of review as anything but the clearly erroneous standard.

Even if the factfinder's demarcation between idea and expression is subject to de novo appellate review, of. Bose Corp. v. Consumers Union of United States, Inc., 104 S. Ct. 1949 (1984) (libel case holding that a finding of actual malice was subject to independent appellate review), a fair use determination would not necessarily be similarly reviewable.

14 Association of Am. Medical Colleges v. Mikaelian, 571 F. Supp. 144, 151 (E.D. Pa. 1983), affd, 734 F.2d 3 (3d Cir. 1984).

146366 F.2d 303 (2d Cir. 1966), cert. denied, 385 U.S. 1009 (1967). For a further discussion of Rosemont, see infra notes 148-51 \& 163-64.

147293 F. Supp. 130 (S.D.N.Y. 1968).

148 The "public interest" concern has been recognized to represent a first amendment value component of fair use. See, e.g., Sobel, Copyright and the First Amendment: A Gathering Storm?, 19 CoPYRIGHT L. SYMP. (ASCAP) 43 (1971). The relationship between copyright and the first amendment has been explored in a number of articles. See, e.g., Denicola, Copyright and Free Speech: Constitutional Limitations on the Protection of Expression, 67 CALIF. L. REv. 283 (1979); Goldstein, Copyright and the First Amendment, 70 Colum. L. Rev. 983 (1970); Nimmer, Does Copyright 
Rosemont, the plaintiff claimed that its copyright in magazine articles on the life of Howard Hughes was infringed by the defendant's book on Hughes. In deciding whether the defendant's use of the copyrighted material was accommodated by the fair use doctrine, the court announced that whether the doctrine "may justifiably be applied to particular materials turns initially on the nature of the materials, e.g., whether their distribution would serve the public interest in the free dissemination of information."148 Although Hughes could "hardly qualify as a Horatio Alger hero in a 'From Rags to Riches' story,"150 the court found that the "public interest" requirement predominated over any damage to the copyright owner because to decide otherwise would be to deprive the public "of an opportunity to become acquainted with the life of a person endowed with extraordinary talents who, by exercising these talents, made substantial contributions in the fields to which he chose to devote his unique abilities."

In the Second Circuit opinion in The Nation, the court relied explicitly on the public interest notion in Rosemont and applied a broad fair use privilege to the verbatim quotations from Ford's memoirs. ${ }^{\mathbf{1 6 2}}$ The court concluded that in a case involving information about important matters of state " $[t]$ o decide otherwise would be to ignore those values of free expression which have traditionally been accommodated by the statute's 'fair use' provisions." 153

In Geis, the defendant author surreptitiously copied photographs of the Kennedy assassination and then used sketches of those photographs in his book critical of the Warren Commission. In finding that the defendant's use was privileged under the fair use doctrine, the court held that "[t]here is a public interest in having the fullest information available on the murder of President Kennedy."154

The "public interest" criterion of Rosemont and Geis is not explicitly listed as a fair use factor under the 1976 Act, ${ }^{105}$ and several commentators have correctly identified this concern for the public interest as reflective of first amendment values. ${ }^{156}$ Nevertheless, to the extent that fair use was able to accommodate such values, the Court's decision

Abridge the First Amendment Guarantees of Free Speech and Press?, 17 UCLA L. REV. 1180 (1970).

140366 F.2d at 307.

180 Id. at 309 .

151 Id.

182 See 723 F.2d at 207-08.

$15 s$ Id. at 208.

154 Geis, 293 F. Supp. at 146.

185 See 17 U.S.C. $\S 107$ (1982), reprinted supra note 13 . The criteria listed are, of course, illustrative only.

${ }_{188}$ See, e.g., Denicola, supra note 148; Sobel, supra note 148. 
in The Nation appears to have made that accommodation impossible. The Court skated over the first amendment argument with a passing nod to the idea/expression distinction and then, without mentioning the concerns articulated in Rosemont and Geis, simply undercut these concerns: "It is fundamentally at odds with the scheme of copyright to accord lesser rights in those works that are of greatest importance to the public. Such a notion ignores the major premise of copyright and injures author and public alike."187

The "public interest" criterion was developed as a way to accommodate uses that could not be justified under confused and restrictive standards of copyrightability and infringement. If there were legitimate first amendment rights present in Rosemont and Geis, then those rights should have been vindicated in the context of a finding of no infringement, and only as a last resort left to the uncertainties of fair use balancing. ${ }^{158}$

The Court was probably correct in declining to apply the public interest criterion in the fair use context, but it was correct for a different reason. Judicial determination of what is sufficiently worthy to qualify as information whose dissemination will serve the public benefit presents serious first amendment concerns that have led the Court, in another context, to abandon forcing judges to determine whether speech "involv[es] matters of public or general concern." "159 In any event, ad-

157105 S. Gt. at 2230.

158 Several copyright scholars have argued for a limited first amendment privilege in copyright doctrine based on the need of a subsequent author to use the expression in order to convey an idea. See, e.g., Denicola, supra note 148, at 306-13; Nimmer, supra note 148 , at 1196-200. These scholars appear to see this privilege as a separate defense that could be invoked after the factfinder determines that an infringement has occurred and that the infringement is not excused under traditional fair use criteria. If such a privilege exists, however, it is because some appropriation of expression is necessary in order to convey an idea. This rationale ostensibly indicates that the issue should be resolved at the infringement stage as part of an inquiry concerning the idea/expression distinction, which, the Supreme Court in The Nation correctly noted, "strike[s] a definitional balance between the First Amendment and the Copyright Act." " $105 \mathrm{~S}$. Ct. at 2229 (quoting The Nation, 723 F.2d at 203). If the first amendment defense is separate, then a second idea/expression inquiry would be required to determine whether the subsequent author's use of the prior author's expression was necessary to convey freely the subsequent author's idea.

159 Rosenbloom v. Metromedia, Inc., 403 U.S. 29, 44 (1971) (plurality opinion) (applying federal defamation standards in an action brought under state law because the alleged defamatory statement concerned an individual's involvement in an event of public or general interest). The approach taken by the plurality in Rosenbloom was abandoned in Gertz v. Robert Welch, Inc., 418 U.S. 323, 346 (1974) (doubting the wisdom of forcing judges to determine "what information is relevant to self-government"). Most recently, in Dun \& Bradstreet, Inc. v. Greenmoss Builders, Inc., $105 \mathrm{~S}$. Ct. 2939 (1985), a plurality of the Supreme Court resurrected the relevance of "public concern" to defamation. See id. at 2945-46. 
herents of the totality approach who have relied on Rosemont and Geis to provide flexibility in fair use analysis must now look elsewhere.

The third truncation of fair use resulting from the Court's opinion in The Nation involves the Court's taking the final step toward establishing a strong presumption against, and broad definition of, "commercial use" in the fair use context. ${ }^{100}$ Although fair use has been applied historically to works involving commercial purpose or use, ${ }^{\mathbf{1 6 1}}$ courts have taken the view that "any commercial use tends to cut against a fair use defense."162 Rosemont, in contrast, had relegated commercial motive to irrelevance as long as the use involved the public interest. The court of appeals had argued that " "a]ll publications presumably are operated for profit" "i6s and had concluded that "whether an author or publisher has a commercial motive or writes in a popular style is irrelevant to a determination of whether a particular use of copyrighted material in a work which offers some benefit to the public constitutes fair use."164

${ }^{100}$ Section 107(1) of the 1976 Copyright Act directs that the factfinder consider "the purpose and character of the use, including whether such use is of a commercial nature or is for nonprofit educational purposes." 17 U.S.C. $§ 107(1)$ (1982), reprinted supra note 13.

181 See, e.g., Eisenschiml v. Fawcett Publications, 246 F.2d 598, 604 (7th Cir.), cert. denied, 355 U.S. 907 (1957) (alleged infringement of copyright in books dealing with Lincoln's death).

182 Triangle Publications v. Knight-Ridder Newspapers, 626 F.2d 1171, 1175 (5th Cir. 1980). Fair use has been denied when the infringing work had a purely commercial purpose. See, e.g., Henry Holt \& Co. v. Liggett \& Myers Tobacco Co., 23 F. Supp. 302, 304 (E.D. Pa. 1938).

${ }^{163}$ Rosemont, 366 F.2d at 307 (quoting Koussevitzky v. Allen, Towne, \& Heath, Inc., 188 Misc. 479, 483, 68 N.Y.S.2d 779, 783 (Sup. Ct.), affd, 272 A.D. 759, 69 N.Y.S.2d 432 (App. Div. 1947)).

${ }^{104}$ Id.; see also Time Inc. v. Bernard Geis Assocs., 293 F. Supp. 130, 146 (S.D.N.Y. 1968) (noting that "hope by a defendant for commercial gain is not a significant factor in this Circuit").

The erosion of Rosemont had begun well before the Supreme Court's decision in The Nation. In Meeropol v. Nizer, 560 F.2d 1061 (2d Cir. 1977), cert. denied, 434 U.S. 1013 (1978), the Second Circuit distinguished Rosemont as a case involving only two direct quotations, and resting in part on the equitable consideration that the plaintiff was acting in bad faith. See id. at 1069. Meeropol was probably wrong on both counts. Rosemont involved two direct quotations and substantial paraphrasing. See 366 F.2d at 306. In addition, the considerations of bad faith discussed in the concurring opinion in Rosemont were expressly not part of the majority opinion. See id. at 305. Although Meeropol acknowledged that commercial gain did not alone defeat a finding of fair use, it stated that "it is relevant whether or not [the copyrighted materials] were used primarily for scholarly, historical reasons, or predominantly for commercial exploitation." Meeropol, 560 F.2d at 1069. Meeropol changed the focus from public interest, where any purpose is irrelevant, to the primary purpose of the use. The Meeropol approach and its implicit rejection of Rosemont were accepted in a number of subsequent cases, some of which purported to rest on Rosemont. See, e.g., M.C.A., Inc. v. Wilson, 677 F.2d 180, 182 (2d Cir. 1981); Iowa State Univ. Research Found. v. American Broadcasting Cos., 621 F.2d 57, 61 (2d Cir. 1980). Further, the focus began 
The Nation's presumption against commercial use clarified the ways in which Sony Corp. v. Universal City Studios, ${ }^{165}$ rendered the Term before, affected fair use analysis, especially the commercial purpose or use aspect of that analysis. In Sony, the Court held that fair use permitted the video recording of entire copyrighted television programs for personal use. In that context, the Court held without discussion or extensive citation that "[i]f the Betamax [videorecorder] were used to make copies for a commercial or profit-making purpose, such use would presumptively be unfair." "168 Sony involved a situation in which users engaged in complete appropriation of the copyrighted programs for no reason other than their own entertainment and convenience. ${ }^{\mathbf{1 6 7}}$ Given that Sony cited the legislative history of the 1976 Copyright Act to the effect that the commercial character of the use was a factor " 'and should be weighed along with other factors in fair use decisions," "168 the Court's "presumption" appears to be an effort to indicate that even though it was taking the rather unprecedented step of allowing an "ordinary use"169 to be a fair use, it would look very unfavorably at "ordinary" uses that were also commercial.

In The Nation, the Court expanded on two aspects of the Sony presumption. First, the Court indicated that, at least when the work used was unpublished, its presumption against commercial purposes applied not only when a "productive use"170 was involved, but also even when the use- "news reporting"-was one explicitly mentioned in the fair use statute as an example of fair use. ${ }^{171}$ Second, the Court adopted the most severe rejection of Rosemont and Geis that had sur-

to shift from whether the case was primarily commercial to whether the user "stood to gain at least indirect commercial benefit." Roy Export Co. v. Columbia Broadcasting Sys., 503 F. Supp. 1137, 1144 (S.D.N.Y. 1980), affd, 672 F.2d 1095 (2d Cir.), cert. denied, 459 U.S. 826 (1982).

185464 U.S. 417 (1984).

168 Id. at 449.

167 See id. at 421.

168 Id. at 449 n.32 (quoting H.R. ReP. No. 1476, 94th Cong., 2d Sess. 66, reprinted in 1976 U.S. CODE CONG. \& AD. NEwS 5659, 5679).

169 An "ordinary use" is the "mere reproduction of a work in order to use it for its intrinsic purpose." Universal City Studios v. Sony Corp., 659 F.2d 963, 970 (9th Cir. 1981) (quoting L. Seltzer, Exemptions aNd FaIR Use IN Copyright 24 (1978)), rev'd, 464 U.S. 417 (1984).

${ }^{170}$ A "productive use" means that "the copier himself is engaged in creating a work of authorship whereby he adds his own original contribution to that which is copied." $3 \mathrm{M}$. NIMMER, supra note 73, at $\S 13.05$ [A][1].

${ }^{171}$ See 105 S. Ct. at 2231 (citing 17 U.S.C. $\$ 107$ (1982), reprinted supra note 13). Professor Latman states that "[n]ews reporting . . . has been traditionally granted latitude . . . . It may well be that the interest in disseminating news suggests an expanding scope of immunity ...." A. Latman, The Copyright Law 208-09 (1979). 
faced in the lower courts: "The crux of the profit/nonprofit distinction is not whether the sole motive of the use is monetary gain but whether the user stands to profit from exploitation of the copyrighted material ...."172

Given that the Court rejected the public benefit criterion in its fair use analysis as it concerned the first amendment, it comes as no surprise that the Court would also reject the Rosemont/Geis interpretation of commercial purpose, which required an initial determination of whether a public benefit existed. Nevertheless, the Court imported from Sony what is perhaps the most severe form of the presumption against commercial purposes, refusing to find "news reporting" a fair use because Navasky stood to profit from his "exploitation" of the memoirs. ${ }^{173}$

As this analysis shows, the Supreme Court truncated significantly the broad fair use doctrine that had been used to assure broad dissemination of factual works. The broad fair use doctrine obviated any necessity for courts and commentators to unravel the complexities involved in copyrightability and infringement standards for factual works. With the utility of fair use now diminished, it becomes necessary to examine those standards.

\section{The "Totality" ApProach to ANALyzing INFRINGEMENT CLAIMS}

Adherents of the totality approach argue that copyright protection ought to extend to totalities of fact and expression. There are several different strands of copyright doctrine that can be labeled "totality" approaches; each strand results in material that is per se noncopyrightable receiving some measure of copyright protection as the result of "merging" with protectible elements. Much of the confusion obfuscating the analysis of factual works by courts and commentators can be traced to a failure to identify what theory was involved in the particular case. The

173105 S. Ct. at 2231.

173 The Court may have used "exploitation" as a normative expression, and not as a synonym for "appropriation." If so, then perhaps the Court did not intend to eliminate evaluation of the purpose of the use in favor of the relatively simplistic determination, likely to be found in the overwhelming majority of cases, that the user "stands to profit" from the use.

Although the Court agreed that Navasky's article was "news," the Court balanced against this consideration the allegedly commercial purpose and the Court's view that Navasky intentionally sought to "scoop" Time magazine by using a "purloined manuscript." Id. at 2232. As the dissent correctly pointed out, such "scooping" constitutes "standard journalistic practice," and the majority's reliance on Navasky's alleged bad faith was unwarranted. Id. at 2248 (Brennan, J., dissenting). 
first totality approach defines protectible expression as including noncopyrightable factual material for purposes of deciding whether a subsequent use of copyrighted material is "substantially similar" to the protected material. The second totality approach applies the standard of infringement for works of fiction to claims of infringement of factual works. The third totality approach protects the overall arrangement and selection of facts in certain situations. All three approaches have appeared in one form or another in modern copyright jurisprudence, and all three approaches play some role in the various analyses used to evaluate the plaintiff's infringement claim in The Nation.

The reason courts must begin to recognize the totality approach in all its guises is that in light of the Supreme Court's decision in The Nation, including the truncation of the fair use doctrine discussed in the previous section, it is now imperative that the totality approach be abandoned. The totality approach in any form fundamentally perverts the goal of copyright law to promote science and the useful arts through the production and dissemination of literary and artistic works. The concern for public benefit reflected in this goal is particularly strong in the case of factual works "because of the public benefit in encouraging the development of [such works] and their public distribution, e.g., so 'that the world may not be deprived of improvements, or the progress of the arts be retarded." "174 The totality approach threatens this concern because it allows material that is noncopyrightable to achieve protected status through combination with admittedly protected expression. It simply makes no sense to recognize that certain material is not capable of copyright protection because of "the basic purpose of copyright law," but then to allow the admittedly unprotectible material to receive protection.

In addition, the totality approach exacerbates the conflict between copyright law and the first amendment. Most commentators ${ }^{\mathbf{1 7 5}}$ and courts $^{178}$ have assumed that there is no conflict, because copyright law protects only expression and leaves unimpeded the free flow of ideas and because the fair use doctrine can accommodate first amendment

174 Rosemont Enters. v. Random House, Inc., 366 F.2d 303, 307 (2d Cir. 1966) (quoting Sayre v. Moore, 102 Eng. Rep. 138, 139 (K.B. 1801)), cert. denied, 385 U.S. 1009 (1967). 1189-93.

${ }_{175}$ See, e.g., Denicola, supra note 148 , at 289-93; Nimmer, supra note 148 , at

${ }^{178}$ See, e.g., Roy Export Co. v. Columbia Broadcasting Sys., 672 F.2d 1095, 1099-100 (2d Cir.), cert. denied, 459 U.S. 826 (1982); Walt Disney Prods. v. Air Pirates, 581 F.2d 751, 758-59 (9th Cir. 1978), cert. denied, 439 U.S. 1132 (1979); Sid \& Marty Krofft Television Prods. v. McDonald's Corp., 562 F.2d 1157, 1168-71 (9th Cir. 1977). 
concerns. We have already seen, however, that the Supreme Court in The Nation has limited the incorporation of first amendment concerns in the fair use context. ${ }^{172}$ Moreover, the more courts rely on the totality approach, the less courts remain true to the balancing of interests underlying the fact/expression distinction. The totality approach frustrates the first amendment interests of subsequent authors.

This section examines the three totality approaches. In separating these approaches, I do not mean to suggest that they are not related either conceptually or by virtue of their combined use in judicial analysis. What does emerge, however, is that there are important differences among the three approaches and that clarification of these differences will ameliorate the tremendous confusion in the copyright analysis of factual works.

\section{A. Totality Analysis and the Subject Matter of Infringement Analysis}

The first and perhaps most common totality approach concerns the subject matter to which the primary test of infringement will be applied. In order to decide whether the defendant has infringed the plaintiff's copyright, the factfinder must determine whether the works are substantially similar to each other. The subject matter totality approach allows a totality, consisting of noncopyrightable material and copyrightable material from the copyrighted work, to be compared to the subsequent work for purposes of determining whether there is substantial similarity between them. Alternatively, courts could employ an "excision" approach; that is, they could remove any noncopyrightable material from consideration before applying the substantial similarity test. These approaches have surfaced repeatedly in copyright cases involving factual works, ${ }^{178}$ fictional works, ${ }^{179}$ and even goods. ${ }^{180}$

\section{See supra notes $146-59$ and accompanying text.}

${ }_{178}$ See, e.g., Fuld v. National Broadcasting Co., 390 F. Supp. 877, 881 (S.D.N.Y. 1975) (employing an excision approach).

${ }_{170}$ Compare, e.g., Sheldon v. Metro-Goldwyn Pictures Corp., 81 F.2d 49 (2d Cir.) (L. Hand, J.), cert. denied, 298 U.S. 669 (1936) with Reyher v. Children's Television Workshop, 533 F.2d 87 (2d Cir.), cert. denied, 429 U.S. 980 (1976). In Sheldon, the defendant movie producer claimed that there was no infringement of the plaintiff's play in part because it was based on historical incidents and dramatic devices that were in the public domain. See $81 \mathrm{~F} .2 \mathrm{~d}$ at 53-54. In reversing the district court's dismissal of the suit, the court of appeals adopted the totality view of copyrightable subject matter: "We are to remember that it makes no difference how far [the plaintiff's] play was anticipated by works in the public demesne which the plaintiffs did not use." Id. at 53. The court of appeals in Reyher affirmed the district court's dismissal of a case in which the plaintiff claimed that the defendant infringed the copyright on a children's storybook. See 533 F.2d at 89 . The court specifically excluded a finding of similarity based on scenes a faire, or "scenes which necessarily result from identical situations." Id. at 92 (footnote omitted).

${ }^{180}$ See, e.g., Eden Toys, Inc. v. Marshall Field \& Co., 675 F.2d 498 (2d Cir. 
In The Nation, the district court applied the subject matter totality approach: it focused its analysis on the "totality of . . . facts and memoranda collected together with Ford's reflections."181 The court of appeals, on the other hand, concentrated only on the use of certain portions of Ford's literal expression with "the uncopyrighted material . . stripped away."182 Finally, although the Supreme Court ostensibly refused to address the issue, and purported to confine itself to a fair use determination only, the Court appeared to sanction the subject matter totality approach in at least two respects. First, the Court created a presumption against the fair use of unpublished material, and failed to distinguish between those portions of unpublished material that are copyrightable and those that are not. ${ }^{183}$ Second, and more importantly, the Court relied on the district court's findings in its own fair use analysis even though those findings were explicitly premised on the district court's totality approach. ${ }^{\mathbf{1 8 4}}$

I will begin this section by examining an early case, Oxford Book Co. v. College Entrance Book Co., ${ }^{185}$ in which the court used both the subject matter totality approach and the excision approach. I will then show how the excision approach is, strictly speaking, inconsistent with the traditional, though ambiguous, rule of Arnstein v. Porter. ${ }^{188}$ Arnstein held that the ultimate determination of substantial similarity is to be made by the trier of fact based on comparisons made without excision of noncopyrightable material. ${ }^{187}$ Nevertheless, I will argue that in light of first amendment concerns as well as the basic purposes of copyright law, the excision approach is superior to the subject matter total-

1982). In Eden, the plaintiff argued that the defendant had infringed the plaintiff's copyrights in two stuffed toy snowmen by also marketing a stuffed toy snowman. See $i d$. at 499 . Although the district court upheld the validity of the plaintiff's copyrights, the court granted the defendant's motion for summary judgment on the ground that the toys were not sutstantially similar. See id. The court of appeals affirmed, holding that it was necessary to separate those characteristics in the plaintiff's design that embodied copyrightable expression from those that expressed a noncopyrightable idea. The court of appeals then determined that there was no substantial similarity between the two different expressions of the same idea of a toy snowman. See id. at 500-01. In dissent, Judge Lumbard argued that the majority erred in its dissection approach, and that the toys should have been compared and viewed as the "ordinary observer" would have regarded them, that is, in their totality. See id. at 501.

181557 F. Supp. at 1072.

182723 F.2d at 206.

18 See $105 \mathrm{~S}$. Ct. at 2223-28, 2232-33.

184 See id. at 2231-35, discussed supra text accompanying notes 86-91.

18898 F.2d 688 (2d Cir. 1938).

188154 F.2d 464 (2d Cir. 1946).

187 See id. at 468. 
ity approach represented by the traditional understanding of Arnstein.

\section{Oxford: A Contrast in Approaches}

In Oxford the defendants appealed the trial court's verdict that the defendants' illustrated American history text infringed the copyright in the plaintiff's illustrated history text. The plaintiff pointed to factual errors in its text and illustrations that also appeared in the defendants' work. ${ }^{188}$ The plaintiff then proffered these errors as conclusive evidence that the defendants copied the work. The defendants admitted access to the plaintiff's work, but also introduced evidence that they gathered material on their own. ${ }^{189}$

Relying on an earlier case that held that copyright does not give a monopoly on the "contents" of a work, ${ }^{100}$ the Oxford court reasoned that although the common errors indicated that the defendants did "use" the plaintiff"s work, the defendants were free to use any information or misinformation contained in the plaintiff's work because "historical facts are not copyrightable per se nor are errors in fact. The plaintiff's book was designed to convey information to the reader."191 Although the defendants could not "copy any substantial part of the copyrighted work," but had to create "something distinctly their own," the court stressed that such independent creation did not "necessarily mean something other than what has been 'put into words' in the copyrighted work" because that would impermissibly grant to the plaintiff a monopoly on the contents. ${ }^{192}$ Copyright protection permits the copyright proprietor only " 'to make use of the corporeal object by means of which the author has expressed himself.' "183 This limited copyright protection was held to apply with particular force to works about the same historical period because "[ $t]$ he subject matter is of necessity what events have made it and the order of treatment whether that be chronological or topical is fixed by the facts."194

Applying this framework of limited copyrightability to the alleged infringement of the plaintiff's text, the court determined that even though there were numerous places in the text where "substantially the

${ }^{188}$ See Oxford, 98 F.2d at 691.

180 See id.

190 See Arnstein v. Edward B. Marks Music Corp., 82 F.2d 275 (2d Cir. 1936) (holding that independent reproduction of a copyrighted work could not constitute infringement).

101 Oxford, 98 F.2d at 691 .

192 Id.

198 Id. (quoting Arnstein v. Edward B. Marks Music Corp., 82 F.2d 275, $275^{\circ}$ (2d

Cir. 1936)).

104 Id. 
same thing on the same subject has been said in different words," the similarity was "inevitable" given the nature of the works. ${ }^{195}$ The court made no attempt to determine whether the defendants' work closely paraphrased the plaintiff's text. As to those patterns of the defendants' work that contained expression identical to the plaintiff's, the court concluded that the similarity was insufficient to establish infringement because certain "phraseology . . . has . . . become more or less stereotyped in some respects in school histories."196

Although the limited copyrightability framework accommodated the defendants' use of text, the court applied a completely different framework to the defendants' illustrations, which in fact combined illustration with verbal description. For example, the plaintiff's work contained an illustration entitled "The Rise of the War Fever" that depicted a thermometer in which the mercury had broken through the top of the glass and the plaintiff had drawn separate lines along the thermometer with dates and verbal descriptions of events leading to the Civil War. ${ }^{187}$ The defendants used an illustration entitled "The Final Blow" that depicted a man labeled "Sectionalism" hitting the plank of a blow tester with a mallet labeled "Slavery." The blow tester had "[s]ubstantially the same dates and events" as the plaintiff's thermometer illustration. ${ }^{188}$ The court, looking at the illustration and labeling as a whole, concluded that "a substantial part of the copyrighted mode of expression was copied." 198 The court affirmed the portion of the lower court's decision that concerned the infringement of various illustrations. ${ }^{200}$

The Oxford case represents an instance when a court applied what was ostensibly the same test of infringement-substantial similarity-in two different ways. First, in examining the text of the two works, the court excised certain noncopyrightable portions of the plaintiff's work-factual information, order, selection-and disregarded "stereotyped" phrases. The court then compared the plaintiff's remaining pro-

195 Id.

${ }^{198} I d$. On this point, the court was ambiguous. On the one hand, the court's analysis suggests that identical language is insufficient to establish copying in all cases when the language is part of stock phraseology. On the other hand, in light of the defendants' admitted access to the plaintiff's work, the court may have been saying that even if the defendants appropriated expression from the plaintiff, such appropriation would be permissible if the appropriation represented stock phraseology.

187 See id. at 693.

$108 \mathrm{Id}$.

$109 \mathrm{Id}$.

200 See id. at 693-94. Judge Manton dissented from the portion of the court's opinion holding that the defendants' illustrations infringed the plaintiff's copyright. See id. at 694 . 
tectible "expression"-the actual words that the plaintiff had used-with the defendants' work. In applying the infringement test to the illustrations, however, the court appeared to look at the respective illustrations as units, and to focus only on whether the similarity between the units was sufficient to show that the defendants copied the plaintiff's illustration in making their own. If the court had not used this totality approach, but rather had disregarded the similarity of dates and events in the illustrations, the court would have found two different illustrations of one noncopyrightable idea: the escalation of the events leading to the Civil War.

\section{The Traditional Test of "Substantial Similarity": The Totality Approach Accepted and Resisted}

The internal conflict in Oxford between the totality approach and the excision approach is representative of the general uncertainty in copyright law concerning how determinations of substantial similarity are to be made and by whom. As discussed below, the excision approach does not fit comfortably within the contours of traditional copyright jurisprudence. The totality approach, however, conflicts with the basic copyright principle prohibiting protection of facts. Moreover, attempts to reconcile the two approaches have met with little success. The result has been doctrinal confusion.

Although substantial similarity is generally a factual issue and the "appropriate test . . . is whether an average lay observer would recognize the alleged copy as having been appropriated from the copyrighted work," ${ }^{201}$ it is now fairly well accepted that this rather broad "audience" test is to be broken down into two stages, as articulated by Judge Jerome Frank in Arnstein v. Porter. ${ }^{202}$ According to Arnstein, the first stage of an infringement analysis requires that the factfinder determine whether the defendant has copied the plaintiff's work. If the determination is based on circumstantial evidence rather than the defendant's admission of copying, the factfinder may, with or without expert testi-

201 Ideal Toy Corp. v. Fab-Lu Ltd., 360 F.2d 1021, 1022 (2d Cir. 1966); accord, e.g., Herbert Rosenthal Jewelry Corp. v. Honora Jewelry Co., 509 F.2d 64 (2d Cir. 1974). For a discussion of the unadorned "audience" test, see 3 M. NIMMER, supra note 73 , at $\S 13.03[\mathrm{E}][2]$.

${ }^{202} 154$ F.2d 464, 468 (2d Cir. 1946). For cases approving the Arnstein framework, see, for example, Hoehling v. Universal City Studios, 618 F.2d 972, 977 (2d Cir. 1980); Sid \& Marty Krofft Television Prods. v. McDonald's Corp., 562 F.2d 1157, 1165 (9th Cir. 1977); Universal Athletic Sales v. Salkeld, 511 F.2d 904, 907 (3d Cir. 1975); Scott v. WKJG, Inc., 376 F.2d 467, 469 (7th Cir. 1967); see also 3 M. NIMMER, supra note 73, at $\S 13.03$ [E][3] (discussing Arnstein's modification of the "audience" test). 
mony, analyze or "dissect" the two works in order to decide whether there is sufficient similarity to prove copying. ${ }^{203}$ In this first stage, the factfinder must compare the two works without regard to whether the similarity rests on protectible or unprotectible material. ${ }^{204}$ In the second stage, the factfinder must decide, without expert testimony or analytical "dissection," whether the "defendant wrongfully appropriated something which belongs to the plaintiff."20s

Arnstein's second stage effectively results in a totality approach. Arnstein viewed both copying and unlawful appropriation as issues of fact, but at the second stage of analysis the factfinder is left completely

203 See Arnstein, 154 F.2d at 468.

${ }^{204}$ See id. The reason for allowing comparison of the works without regard to whether particular elements are protectible was stated by then District Judge Kaufman in Morse v. Fields, 127 F. Supp. 63 (S.D.N.Y. 1954):

If we assume that there is but one sentence of a plaintiff's work which is both protected and material and the vast residue is unprotected, and the claim is the copying of this one sentence by evasion, obviously a holding which excludes a showing of identity or close similarity between the vast unprotected residue of plaintiff's work and the bulk of a defendant's work would eliminate any possibility of a finding of copying of the one protected sentence.

Id. at 66 n.3.

${ }^{205}$ Arnstein, 154 F.2d at 473 (footnote omitted). In Sid \& Marty Krofft Television Prods. v. McDonald's Corp., 562 F.2d 1157 (9th Gir. 1977), the court applied a modified version of the Arnstein test. Under the approach adopted in Krofft, the first stage in determining whether there was infringement is the "extrinsic test," which requires that the factfinder, with the aid of analytic dissection and expert testimony, decide if there is substantial similarity between the ideas in the two works. See id. at 1164. If the factfinder concludes that there is idea similarity, then the factfinder must decide, without the aid of analytic dissection and expert testimony, whether there is substantial similarity of expression. This second-stage analysis is the "intrinsic test." See id. Although the court in Krofft noted that it "[believed] that the Arnstein court was doing nearly the same thing" in the Arnstein two-stage process, id. at $1165 \mathrm{n} .7$, the court claimed that its extrinsic/intrinsic test did "not resurrect the Arnstein approach." Id. The court in Krofft seemed to recognize that only expression is protected by copyright, see id. at 1163 , but then held that in order for there to be infringement, there must be "substantial similarity not only of the general ideas but of the expressions of those ideas as well." Id. at 1164. This notion of idea and expression similarity finds no support in copyright law.

Moreover, Krofft's extrinsic test is arguably inconsistent with Arnstein's first stage. The Krofft extrinsic test ostensibly requires that the factfinder determine whether there is substantial similarity of ideas, while the first stage of the Arnstein test requires that the factfinder determine whether there has been copying based on substantial similarity between the works taken in their entireties. Professor Nimmer has concluded, therefore, that Krofft's extrinsic test appears to give the trier of fact a greater role in the infringement decision than he understands to be the case under the first stage of the Arnstein test. See 3 M. NIMMER, supra note 73, at $\$ 13.03[\mathrm{E}][3]$.

Courts, in contrast, have generally not treated Arnstein and $K r o f f t$ as two different tests; even the Ninth Circuit appears to have interpreted $K r o f f t$ as consistent with Professor Nimmer's understanding of Arnstein. See, e.g., See v. Durang, 711 F.2d 141, 143 (9th Cir. 1983). 
on her own to decide whether the appropriation is an unlawful appropriation. Expert testimony, as well as resolution of works into constituent parts, is not permitted. ${ }^{208}$ Even though Arnstein, relying on $O x$ ford, recognized the need for distinguishing permissible copying from impermissible copying, ${ }^{207}$ it provided no guidance to the trier of fact attempting to draw that distinction. Indeed, the Arnstein court emphasized that the "unlawful appropriation" inquiry is an "issue of fact which a jury is peculiarly fitted to determine" and that "even if there were to be a trial before a judge, it would be desirable (although not necessary) for him to summon an advisory jury on this question."208 Given the unadorned "lay observer" test as well as the Arnstein analysis, a factfinder could not be expected to ignore factual material and the sequence in which it is presented from consideration of substantial similarity, because, at this second stage, there is no mechanism for the trier of fact to distinguish copyrightable material from noncopyrightable material.

Recognition of the need to draw a distinction between permissible and impermissible copying has resulted in various judicial attempts to circumvent Arnstein's de facto totality approach. There have been three different responses to this problem. First, some courts have advocated an initial determination of noncopyrightability based on a lack of originality and creativity. For example, in Amsterdam v. Triangle Publications, ${ }^{209}$ the court denied copyright protection to the plaintiff's map, which had been compiled from other maps but which alone contained all of the collected information. The court reasoned that the plaintiff's map lacked the requisite originality, in that the plaintiff had merely collated the preexisting maps and added only "an infinitesimal amount of original information." "2210

${ }^{206}$ See id. at 468

207 See id. at 472. The Arnstein court must have meant that in the second stage the factfinder was to decide whether substantial similarity existed by referring only to protectible expression rather than to the entire works. During the first stage, the factfinder must determine on the basis of substantial similarity whether the defendant has copied the plaintiff's work. The considerations of substantial similarity must be different or else the copying determination would suffice to decide both issues. Given that the Arnstein court spoke of "permissible" copying as the focus of the second stage, it is most likely that the court intended similarity of protectible expression to be considered at this stage.

208 Id. at 473.

209189 F.2d 104 (3d Cir. 1951).

210 Id. at 106 (quoting Amsterdam v. Triangle Publications, 93 F. Supp. 79, 82 (E.D. Pa. 1950), modified, 189 F.2d 104 (3d Cir. 1951)). A similar case irvolving a nonfactual work is Morrissey v. Procter \& Gamble Co., 379 F.2d 675 (1st Cir. 1967). In Morrissey, the plaintiff alleged that the defendant infringed a copyright in a set of sweepstakes rules involving the contestants' social security numbers. The court held that the subject matter involved was so narrow that it could be expressed only in a very 
The second response involves a judicial determination that substantial similarity between copyrightable works does not exist as a matter of law because all alleged similarities are to noncopyrightable material. This approach, which allows courts to determine lack of substantial similarity by summary judgment, evolved in an important set of recent cases in the Southern District of New York-Fuld $v$. National Broadcasting Co., ${ }^{211}$ Gardner v. Nizer, ${ }^{212}$ and Alexander v.

limited number of ways. Moreover, "copyright does not extend to the subject matter at all, and the plaintiff cannot complain even if his particular expression was deliberately adopted." Id. at 679.

Morrissey reflects the doctrine of "functional inseparability." This doctrine holds that '[ $w]$ hen the 'idea' and its 'expression' are . . . inseparable, . . . copying the 'expression' will not be barred, since protecting the 'expression' in such circumstances would confer a monopoly of the 'idea' upon the copyright owner free of the conditions and limitations imposed by the patent law." Herbert Rosenthal Jewelry Corp. v. Kalpakian, 446 F.2d 738, 742 (9th Cir. 1971); accord Herbert Rosenthal Jewelry Corp. v. Honora Jewelry Co., 509 F.2d 64, 65 (2d Cir. 1974). For a further discussion of the relationship between functional inseparability and the totality approach, see infra note 265 .

211390 F. Supp. 877 (S.D.N.Y. 1975). Fuld involved a claim that the defendant had infringed the plaintiff's copyright in a script concerning the life of a famous gangster by broadcasting a television movie focusing on the life of the gangster's girlfriend. See id. at 878 . The defendant moved for summary judgment on the ground that there was no relevant similarity between the works. For purposes of this motion, the defendant conceded access to the plaintiff's script. See id.

The court assumed that the plaintiff's script was the only source of information that the defendant possessed about the characters and events, but the court noted that the facts contained in the plaintiff's script were also contained in other published works. After reciting the contents of the script and movie versions, the court concluded that "it is at once apparent that plaintiff can claim credit for much of the information conveyed in the movie." Id. at 880-81. Nevertheless, the court granted the defendant's motion for summary judgment because there could be no copyright protection in historical fact, order of presentation of facts, or even in the selection of facts, " "although into that selection may go the highest genius of authorship, for indeed, history depends wholly upon a selection from the undifferentiated mass of recorded facts." "Id. at 882 (quoting Myers v. Mail \& Express Co., 36 Copyright Office Bull. 478, 479 (S.D.N.Y. 1919) (L. Hand, J.)). In addition, the court relied on the related axiom that copyright protection did not extend to "ideas, themes, locale or characters in . . . [the] copyrighted work . . . [but only to] the means of expression of those ideas and themes-or manner of use and development of those characters." Id. at 881. The defendant's treatment of these noncopyrightable elements differed from the plaintiff's expression.

212391 F. Supp. 940 (S.D.N.Y. 1975). In Gardner, the plaintiff argued that the defendants' book violated the plaintiff's copyright in a biography of Julius and Ethel Rosenberg. The court relied on copyrightability, infringement standards, and fair use to enter summary judgment for the defendants. First, the court stated the axiom that facts and events are not copyrightable. See id. at 942 . For this proposition, however, the Gardner court inexplicably cited a portion of Rosemont Enters. v. Random House, Inc., 366 F.2d 303 (2d Cir. 1966), cert. denied, 385 U.S. 1009 (1967), holding that for fair use purposes it was "reasonable and customary" for subsequent authors to use earlier historical and biographical works. See 391 F. Supp. at 942 (citing Rosemont, 366 F.2d at 307). The court could have cited the portion of Rosemont that did address the issue of the copyrightability of factual information. See Rosemont, 366 F.2d at 304, 306. Adding to this confusion, the court left unclear whether it disregarded similarity 
Haley ${ }^{213}$-and was affirmed by the Second Circuit in Hoehling v. Universal City Studios. ${ }^{214}$ These cases represent an adherence to the principle that factual information, including arrangement and selection of facts, is not copyrightable and the view that in cases involving factual works a finding of substantial similarity for infringement purposes must be predicated on appropriation of literal expression. What is particularly interesting is that the courts in these cases did not regard it as necessary to have a trier of fact decide the issue of substantial similarity or to decide what elements would be included in making such a

based on factual information because that information was not copyrightable or because the court viewed as uncontradicted the defendants' assertions that the factual information was gathered independently from common sources. Second, the court, relying on Oxford, held that although the plaintiff's literal form of expression was protected, "the copying must be even more substantial to constitute infringement when historical works are involved." Gardner, 391 F. Supp. at 943-44. Third, the court held that even if the defendants infringed the plaintiff's copyright, the infringement would be excused by the public benefit referred to in Rosemont because any similarity was "not virtually complete or verbatim." Id. at 944.

213460 F. Supp. 40 (S.D.N.Y. 1978). Alexander evinced a much more careful use of the standard governing summary judgment than did Fuld or Gardner. In Alexander, the plaintiff claimed that his combined factual/fictional work on the history of black slavery in the United States was infringed by the defendant's book, Roots. See id. at 42 . The court recognized that although the question of substantial similarity between the works is one of fact, Gardner, Fuld, and other cases indicated that if the claimed similarities were predicated on materials not protectible by copyright, then those similarities could be disregarded as a matter of law. See $i d$. at 44 . The court then resolved the plaintiff's claims into various categories of material, all of which the court held to be noncopyrightable. These categories were (1) similarities based on fact, even if the defendant learned those facts from the plaintiff's work; (2) similarities based on materials traceable to common sources; (3) similarities based on scenes a faire or "incidents, characters or settings which are as a practical matter indispensible, or at least standard, in the treatment of a given topic"; (4) similarities based on cliche language or metaphors; and (5) similarities based on theme or setting that are unprotectible as ideas. See id. at $45-46$.

214618 F.2d 972 (2d Cir. 1980). In Hoehling, the court of appeals affirmed summary judgment against the plaintiff, which had claimed that its copyright in a book about the destruction of the Hindenburg dirigible was infringed by the defendants' book and motion picture based on that book. The essential portion of the plaintiffs book was the thesis that the Hindenburg had been sabotaged by a member of the crew in order to impress a female acquaintance. The court acknowledged that although substantial similarity ordinarily presents an issue of fact, Alexander, Gardner, and Fuld established that summary judgment is proper when "all alleged similarity relate[s] to non-copyrightable elements of the plaintiff's work." Id. at 977. The Hoehling court then examined the similarities and concluded, as had the district court, that all were predicated on noncopyrightable elements. See id. at 977-79. These similarities included ones based on interpretation of an historical event, specific fact, and scenes a faire. Although the court recognized that the line between idea and expression normally presents an issue of fact, when the "idea" is historical interpretation there is noncopyrightability as a matter of law. See id. at 980 . The Hoehling court cited the portion of Rosemont that concerned fair use, thus confusing copyrightability and fair use. In doing so, the court committed the same error as the court in Gardner; as noted above, the court could have cited the portion of Rosemont that addressed copyrightability. See supra note 212. 
determination. $^{215}$

The third response is typified by cases like Oxford, in which appellate courts engage in what is tantamount to a de novo determination of the "unlawful appropriation" stage of Arnstein. Two recent examples of this approach have arisen in the Third Circuit. In Universal Athletic Sales Co. $v$. Salkeld, ${ }^{216}$ the district court found that the defendant copied the plaintiff's work, but did not make the additional finding required under Arnstein that the "copying went so far as to constitute improper appropriation, the test being the response of the ordinary lay person."217 The appellate court noted that it would normally remand this factual issue to the district court, but because the second stage of Arnstein required no determination of credibility, the court held that it was "in as good a position to determine the question as . . . the district court, ${ }^{, 218}$ and concluded that the lay observer could not find that there was substantial similarity of protected expression. ${ }^{219}$ In Franklin Mint Corp. v. National Wildlife Art Exchange, Inc., ${ }^{20}$ the appellate court affirmed the district court based on its finding that there was no copying by the defendant; the court held in the alternative that even if the district court erred in its finding of no copying, it should be affirmed based on the second Arnstein factor: "[B]ased upon our own observations and impressions, we conclude that while the ideas are similar, the expressions are not."221

The one thing that can be said about all three responses to the factfinder's unaided responsibility to distinguish permissible copying from impermissible copying is that even though none of these cases repudiates or even questions Arnstein-indeed, two claim to apply Arnstein $^{222}$-it is difficult to reconcile any of the responses with the second stage of Arnstein's infringement analysis. Although the factfinder may "dissect" the works when deciding whether the copyrighted work was copied, close analysis and expert testimony are supposedly "irrelevant" in the second stage. ${ }^{223}$ The ultimate issue of infringement is one of fact,

216 For discussions of these cases, see supra notes 211-14.

216511 F.2d 904 (3d Cir. 1975).

217 Id. at 907.

218 Id.

219 See id. at 909.

220575 F.2d 62 (3d Cir. 1978).

221 Id. at 67.

${ }_{222}$ See Hoehling v. Universal City Studios, 618 F.2d 972, 977 (2d Cir. 1980); Universal Athletic Sales Co. v. Salkeld, 511 F.2d 904, 907 (3d Cir. 1975).

${ }^{223}$ See Arnstein, 154 F.2d at 468. A later court purporting to echo the Arnstein bifurcated approach refused to allow the defendant to analyze the constituent parts of the works in order to show that idea, not expression, was similar, and went so far as to say, "Lest we fall prey to defendants' invitation to dissect the works, . . . we should remember that it is the combination of many different elements which may command 
and must be decided in accordance with the impression of the lay audience. $^{224}$ This factual issue has consistently been treated under the "clearly erroneous" standard for purposes of appellate review. ${ }^{225}$

If the trier of fact is supposed to evaluate the combination of the elements contained in factual works in their entireties, and is not to dissect or analyze the works in order to decide whether the appropriation is wrongful, the three judicial responses outlined above appear to invade the factfinder's province. In Arnstein, the court did acknowledge that treating the wrongful appropriation as an issue of law might be permissible in certain limited circumstances, such as when "Ravel's 'Bolero' or Shostakovitch's 'Fifth Symphony' were alleged to infringe 'When Irish Eyes Are Smiling.' "226 This example, however, illustrates that the factfinder might be excluded only when there is a clear absence of similarity, not when the trier of fact could reasonably decide that the defendant has wrongly appropriated a substantial portion of the combination of noncopyrightable and copyrightable elements that results in copyright protection. When a court denies copyright protection $a b$ ini$t i o,{ }^{227}$ or, more importantly, views the issue of wrongful appropriation as a matter of law either in the context of a motion for summary judgment or in its review of the factfinder's application of the second portion of Arnstein, the result is judicial "dissection," an approach that the Arnstein analysis seemingly forbids in the second stage.

This observation illustrates the difficulties with suggestions, put forward by various copyright scholars, that factual works should be deemed fully copyrightable to avoid their "unadorned appropriation,"228 and that unfettered access to factual information should then

copyright protection because of its particular subjective quality." Sid \& Marty Krofft Television Prods. v. McDonald's Corp., 562 F.2d 1157, 1169 (9th Cir. 1977). This refusal to permit close analysis and expert testimony reflects the standard "lay observer" test for infringement that was adopted as the second stage in Arnstein.

A recent case that indicates the confusion inherent in the Arnstein two-pronged approach is Walker v. Time Life Films, Inc., 12 Media L. REP. (BNA) 1634 (2d Cir. Jan. 7, 1986).

226 Professor Nimmer notes that the unadorned audience test (before Arnstein) "may not always prove an accurate guide to ferreting out the existence of literary theft." $3 \mathrm{M}$. NIMMER, supra note 73, at $\S 13.03$ [E][2]. Acceptance of the Arnstein analysis does not ameliorate this concern, because the ultimate issue of wrongful appropriation will be decided by the impression of the factfinder.

${ }_{225}$ See, e.g., Sid \& Marty Krofft Television Prods. v. McDonald's Corp., 562 F.2d 1157, 1164 (9th Cir. 1977); International Luggage Registry v. Avery Prods., 541 F.2d 830, 831 (9th Cir. 1976); Eisenschiml v. Fawcett Publications, 246 F.2d 598, 603

(7th Cir. 1957).

226154 F.2d at 473.

${ }^{227}$ For a discussion of the conceptual difficulties involved when courts take the approach that whole works are noncopyrightable $a b$ initio, see Gorman, supra note 3. ${ }^{228}$ Id. at 567. 
be guaranteed by applying traditional substantial similarity criteria. ${ }^{229}$ The difficulty with this argument is apparent: although the degree of protection afforded to individual portions of the copyrighted whole is to be decided under the traditional substantial similarity criteria, the standard Arnstein test simply does not allow an analysis of individual portions to be made at the second, wrongful appropriation stage. If one of the three "dissection" approaches outlined above is followed, the issue of copyrightability will eventually be determined, but at a later stage of the infringement analysis and in apparent violation of the traditional rule.

The subject matter totality approach followed by the district court in The Nation, then, is merely the result of following standard copyright infringement analysis. The district court refused to remove from its consideration those portions of the memoirs that it acknowledged were not per se copyrightable, but in determining the ambit of copyright protection, the court treated these noncopyrightable portions as somehow merged with Ford's "reflections" and "revelations" about these facts. The court of appeals removed from its consideration the noncopyrightable elements, and, as stated earlier, the Supreme Court purported not to address the issue but nevertheless based its fair use analysis on district court findings that were predicated on the totality approach. ${ }^{230}$

\section{The Need for a Narrower Role for Factfinders in Infringement Determinations}

The traditional Arnstein test for determining whether substantial similarity between two factual works exists provides too broad a role for factfinders, and therefore leaves subsequent authors insufficiently protected. Arnstein allows the line between idea and expression to be drawn by the factfinder subject to review only under the clearly erroneous standard. An ultimate determination of wrongful appropriation is

229 See, e.g., id. at 568-72; Denicola, supra note 22, at 527-32. This similarity in approach does not mean that Professors Gorman and Denicola share the same views on this issue. Professor Gorman argues for liberal copyrightability standards, but then applies various criteria to determine the scope of protection at the infringement and fair use stages. See Gorman, supra note 3, at 568-72. Professor Denicola argues that copyright ought to extend to the aggregation and collection of data in compilations as well as to the assemblage of facts appearing in nonfiction narratives. He would guard the per se noncopyrightability of facts by applying ordinary infringement principles. See Denicola, supra note 22, at 527-32. What Professor Denicola shares with Professor Gorman is the view that copyrightability issues can be resolved at the infringement stage.

230 See supra text accompanying notes 86-91. 
dependent on the factfinder's decision that substantial similarity exists between protected expression in the original work and the corresponding expression in the alleged infringing work. Under the Arnstein test, however, there is no way for the factfinder to separate unprotected ideas from protected expression. Consequently, the characterization of a copyright defendant's speech will be an issue of fact in each case; unprincipled, ad hoc decisionmaking will result, as Judge Hand warned. ${ }^{231}$ This difficulty precludes reliance on the idea/expression distinction as a means of avoiding the conflict between copyright protection and the first amendment.

Although it makes sense to allow the factfinder to decide the issue presented by the first stage of the Arnstein inquiry-whether the defendant copied the plaintiff's work-permitting the factfinder to determine wrongful appropriation subject to the "clearly erroneous" standard of review is somewhat peculiar in light of the first amendment implications of this determination. In traditional first amendment jurisprudence, "the limits of the unprotected category, as well as the unprotected character of particular communications, have been determined by the judicial evaluation of special facts that have been deemed to have constitutional significance. ${ }^{\text {232 }}$ For instance, in Connick v. Myers, ${ }^{283}$ the Supreme Court held that whether an employee's speech was a matter of "public concern" was an issue of law and therefore not subject to the clearly erroneous standard. ${ }^{234} \mathrm{~A}$ similar observation may be made about the characterization of speech as libelous, ${ }^{235}$ as constituting "fighting words,"296 or even as being obscene. ${ }^{237}$ In Bose Corp. ข. Consumers Union of the United States, Inc., ${ }^{\mathbf{2 3 8}}$ the Court determined that reviewing what was ostensibly a purely historical fact about state of mind-whether a libel defendant had actual malice-was an issue that required the appellate court to perform a de novo review to determine whether the record established actual malice with convincing clarity. ${ }^{239}$

Especially after Bose, there may be no justification for according special treatment to the factfinder's determination that the defendant's action constituted a prohibited use of protected expression rather than a

231 See Peter Pan Fabrics, Inc. v. Martin Weiner Corp., 274 F.2d 487, 489 (2d Cir. 1960); see also supra note 113 and accompanying text.

62 (1984).

${ }^{232}$ Bose Corp. v. Consumers Union of United States, Inc., 104 S. Ct. 1949, 1961-

29s 461 U.S. 138 (1983).

234 See id. at 148 n.7.

2as See, e.g., Time, Inc. v. Pape, 401 U.S. 279, 290 (1971).

238 See, e.g., Street v. New York, 394 U.S. 576, 589, 592 (1969).

${ }^{237}$ See, e.g., Miller v. California, 413 U.S. 15, 23-24 (1973).

238104 S. Ct. 1949 (1984).

${ }^{239}$ See id. at $1964-65,1967$. 
permitted use of unprotected ideas. In the event that such determinations continue to receive "preferred" treatment, the only possible explanation for such treatment is that the idea/expression distinction is elusive and so must be made at least initially by a trier of fact. Even if the characterization of the defendant's speech is a matter for the trier of fact in the first instance, Bose suggests that the clearly erroneous standard of appellate review should not apply when first amendment issues are involved.

Moreover, it is not clear that factfinders in cases involving factual works should have to draw the line between idea and expression, even initially. In cases involving fictional works, the idea/expression distinction is extremely difficult to draw and judicial dissection is almost impossible. Once judges perform the dissection, they have already made essentially the same decision that triers of fact are being asked to make. $^{240}$ Thus, in cases involving fictional works there may be some justification for allowing the factfinder to make the initial determination of wrongful appropriation. The same is not true for factual works. With such works, judges are perfectly capable of stripping away the noncopyrightable factual material so that there can be no combination of unprotectible and protectible elements. The distinction between fact and expression is simply different from the distinction between idea and expression. ${ }^{211}$ Recognition of this difference in no way frus-

240 This problem is reflected in nebulous judicial and academic formulations, such as Judge Hand's "abstractions test," see Nichols v. Universal Pictures Corp., 45 F.2d 119, 121 (2d Cir. 1930), cert. denied, 282 U.S. 902 (1931), discussed supra note 113, and Professor Chafee's "patterns test," see Chafee, supra note 113, at 513. Although intended to facilitate drawing the distinction between unprotectible ideas and protectible expression, these "tests" do little more than restate the problem of distinguishing idea from expression, thus providing no concrete standard to aid the factfinder in what is essentially an "ad hoc" decision. See Peter Pan Fabrics, Inc. v. Martin Weiner Corp., 274 F.2d 487, 489 (2d Cir. 1960).

241 Some copyright scholars have rejected the notion that facts and factual interpretations are logically different from other types of works and have argued for an expansive view of the meaning of "factual expression." See, e.g., Ginsburg, supra note 22 , at 650 (arguing that historical writing represents an author's particular perspective "as shown through his synthesis of the components," which "is the hallmark of authorship, and the essence of expression"); see also Patry, supra note 22, at 633 (adopting Ginsburg's view that a nonfiction writer is entitled to the protection of her narration of the facts). Professor Ginsburg argues that the failure to protect historical facts and theories rests on the "Platonic fact precept," according to which facts and theories have the epistemological status of truth. See Ginsburg, supra note 22, at 658. She rejects the "objective" theory because historical writing does not reveal the "truth," but reveals only "the author's perceptions and inclinations. If an historical 'truth' in the Platonic sense exists, it can never be discovered, because the same diversity of understanding, approach, and predilection which makes every personality unique precludes a unity of historical interpretation." Id.

It is unclear whether Professor Ginsburg means to argue that the notion of factual truth is meaningless, or that historical interpretation is on a different epistemological 
trates-and actually advances-the purposes of copyright law, and reduces tension between copyright and the first amendment that might otherwise be inevitable given the current theory of copyright infringement. The judicial responses to Arnstein outlined above may not fit comfortably with Arnstein itself, but they serve far better the fundamental purposes of copyright law and the first amendment.

\section{B. Totality Analysis and the Standard for Infringement of Protectible Expression}

Irrespective of how the subject matter of protectible expression is determined, there will still remain a further issue: content must be given to the "substantial similarity" standard of infringement for factual works. ${ }^{242}$ That is, even if the trier of fact is permitted to consider only judicially defined expression, or the appellate court draws its own line between idea and fact or expression, it will still be necessary to determine whether the defendant's use has amounted to an infringement of the plaintiff's protectible expression, however defined. A court may hold that the fact represented in an utterance is not copyrightable, but that the expression of the fact is copyrightable. The court would still have to determine whether a second utterance embodying the same fact infringes the expression contained in the first utterance.

The traditional judicial and academic standards for determining whether subsequent use of material beyond literal reproduction consti-

level from a bare historical fact. If Professor Ginsburg intends the former, then her skepticism seems to be itself a "metaphysical" view that flies in the face of ordinary language, a view that at least some "factual assertions" are epistemologically different from other assertions. For example, most people would regard the assertion that " $X$ died in 1915" as being an assertion logically different from an assertion in a work of fiction about a fictional character. Professor Ginsburg betrays even her own adherence to some form of "objectivist" theory in her acknowledgment that facts are properly placed beyond the scope of copyright. See id. at 664, 666 .

If, on the other hand, Professor Ginsburg means that historical interpretations and arguments should be regarded as epistemologically different from facts, then her argument is equally puzzling and her own views again contradictory. There is logically no reason to treat an interpretation of a set of facts as different from a fact itself. A theory about historical facts is based on either direct or circumstantial evidence. A statement of fact may also be supported by direct or circumstantial evidence. In the context of another argument, Professor Ginsburg acknowledges that if two historians offer two different interpretations of the same event, "[a]t least one of [the] interpretations must be false." Id. at 660 . If her argument is that an interpretation of facts, as distinguished from the facts themselves, represents not "truth" but merely "the author's perceptions and inclinations," id. at 658 , it is difficult to reconcile this view with the view that interpretations may be true or false.

242 Obviously, the character of this issue will vary considerably depending on whether the protectible expression has been dissected by the court beforehand in order to remove factual information. 
tutes infringement-such as Judge Hand's "abstractions test"243 or Professor Chafee's "patterns test" 244 -involve criteria that have been developed for the most part in the context of assessing infringement claims related to fictional works. These standards, which focus more on the distinction between idea and expression and less on whether two sets of expression are substantially similar, dictate that infringement exists if there is only a minor variation between two sets of expression. ${ }^{245}$

Under the second version of the totality approach, a court determines whether expression has been infringed by applying a single standard of substantial similarity regardless of whether the expression at issue is factual or fictional. ${ }^{248}$ Although there are differences in approach, the commentators are almost unanimous in their view that the scope of protectible expression in factual works should be determined by the standards applied to fictional works. ${ }^{247}$ The problem with this

${ }^{243}$ See Nichols v. Universal Pictures Corp., 45 F.2d 119, 121 (2d Cir. 1930), cert. denied, 282 U.S. 902 (1931), discussed supra note 113.

244 See Chafee, supra note 113, at 513.

245 See Nichols v. Universal Pictures Corp., 45 F.2d 119, 121 (2d Cir. 1930), cert. denied, 282 U.S. 902 (1931); Chafee, supra note 113, at 513. The court's task under an "abstractions" or "patterns" test is essentially to separate unprotectible ideas from protectible expression. See, e.g., Warner Bros. v. American Broadcasting Cos., 654 F.2d 204, 208 (2d Cir. 1981) (explaining Judge Hand's abstractions test).

${ }^{246}$ Some commentators have argued that references to "wholesale usurpation" in cases involving factual works, see, e.g., Hoehling v. Universal City Studios, 618 F.2d 972, 974 (2d Cir.), cert. denied, 449 U.S. 841 (1980), are intended to provide a new (and unacceptable) standard for determining the infringement of factual works. See, e.g., Ginsburg, supra note 22, at 650-56; Gorman, supra note 3, at 593; Patry, supra note 22 , at 654 n.126. Although issues concerning the "wholesale usurpation" standard are related to this second totality approach, they are sufficiently different to justify separate treatment. See infra notes 282-366 and accompanying text.

A view related to the single-standard approach is that when a subsequent author uses verbatim quotations from a copyrighted work, infringement is automatically established, and the permissibility of the work must then be decided under the fair use doctrine. See, e.g., The Nation, $105 \mathrm{~S}$. Ct. at 2224. Any such assumption conflicts with the notion that when there has been a verbatim use of protected material, the issue is whether there has been a substantial taking of the material. Professor Nimmer labels this issue "fragmented literal similarity." See $3 \mathrm{M}$. NIMMER, supra note 73, at $\S 13.03[\mathrm{~A}][2]$. Professor Nimmer argues that although the issue of fragmented literal similarity is often resolved under a fair use analysis, such a determination does not make clear whether there is "an insubstantial similarity regardless of the defendant's use, or ... [whether there is] substantial similarity which would constitute an infringement but for the particular purpose." Id.

To the extent that the issue of substantial taking is resolved in the context of fair use, which calls for the purely ad hoc balancing of many factors, this assumption represents another instance of totality analysis because it creates a dangerous potential for according protection where resolution at the infringement stage would prohibit such protection. See infra notes $270-81$ and accompanying text.

247 See Ginsburg, supra note 22, at 649-50, 666-73; Gorman, supra note 3, at 593; Patry, supra note 22, at 653-55. But see $3 \mathrm{M}$. NIMMER, supra note 73 , at 
approach is that for logical and practical reasons the infringement standards for fictional and factual works must be different. It is not practical to apply the tests developed for fictional works to determine whether there has been infringement of factual expression because there will be many instances in which only minor variations will exist between two sets of factual utterances, but a finding of infringement would run contrary to basic copyright principles. Applying the inapposite standards for the infringement of works of fiction to works of fact threatens unjustifiably to accord copyright protection to unprotectible information. Such application thereby represents a totality analysis.

The tension between the competing standards for infringement of protectible expression is typified by the lower court opinions in The Nation. The district court considered Navasky's paraphrasing of Ford's memoirs an infringement not excused by fair use. On the other hand, the court of appeals rejected "the argument that paraphrasings of disparate facts such as those found in [The Nation constituted] an infringement of copyrightable material."248 Recognizing that there were only so many ways in which the factual assertions in Ford's memoirs could be expressed, the court of appeals permitted Navasky to paraphrase these facts closely. The Supreme Court did not focus on the paraphrasings, but stated that its fair use analysis of the verbatim quotations "was not intended to endorse any particular rule of copyrightability."249

In this section, I will examine and reject the proposition that the

$\S 13.03[\mathrm{~A}][1]$ ("[I]f the only original aspect of a work lies in its literal expression, then only a very close similarity, verging on the identical, will suffice to constitute an infringing copy.").

Professor Gorman argues that "literary expression in ... works [of history and biography] should be entitled to no less protection than literary expression in works of fancy (and arguably to even more protection)." Gorman, supra note 3, at 593. Further, in the context of discussing copyright protection in maps, Professor Gorman asks, "[H]ow does a court decide what is infringement and what is an allowable use when the defendant borrows more than the discovered geographic facts but less than the whole map configuration?" Id. at 568. He answers that

[a]s a matter of general theory, the problem is not significantly different from determining whether the author of the motion picture "The Cohens and The Kellys" copied merely the general theme of the successful play "Abie's Irish Rose" or rather went too far and copied as well the plot details and sequence of incidents.

Id. (citing Nichols v. Universal Pictures Corp., 45 F.2d 119 (2d Cir. 1930), cert. denied, 282 U.S. 902 (1931)). Professor Gorman argues that in the case of maps liberal borrowing ought to be permitted, but he maintains that such use can be accommodated under either infringement or fair use doctrines. $I d$. at 569-70.

248723 F.2d at 203.

$249105 \mathrm{~S}$. Ct. at 2233 n.8. But cf. id. at 2243-44 (Brennan, J., dissenting) (arguing that Navasky's paraphrasing was not infringement). 
same standard of infringement should apply to both factual and fictional expression. There are simply a limited number of ways in which an unprotectible fact can be expressed; thus, if courts do not allow generous use of factual expression, they risk according protection to noncopyrightable facts. In this context, I will consider and reject arguments intended to show that there can be sufficient variation between factual utterances so that it is permissible to apply the traditional standards of infringement applicable to fictional works. I will then discuss a related problem involving a disturbing trend in copyright law toward resolving the threshold issue of infringement in the completely inappropriate context of determining whether there has been a fair use-a doctrine that, when applied properly, assumes that there has been an infringement. The point of this second discussion is to show that sometimes courts and commentators recognize that factual expression is different, but, rather than recognizing this difference at the infringement stage, leave consideration until the far more uncertain stage of fair use. The problem with this approach is that in the fair use context what is essentially an infringement question may be resolved incorrectly in favor of according copyright protection because of the equitable aspects of the fair use doctrine.

\section{Infringement and the Limitations of Factual Expression}

An example of the limited number of ways in which facts can be expressed may be helpful both for understanding the second form of totality analysis and for distinguishing it from the totality approach discussed in the previous section. Assume that author $X$ produces a copyrighted history containing the following:

The end of the medieval papacy occurred in 1305 when the cardinals elected Clement V, a Frenchman, to the papacy. Clement V was regarded as an able intellectual, but was timid, and was very subservient to the French throne.

Author $Y$, who admits using author $X$ 's work, produces a second history containing the following:

In 1305 , Clement $\mathrm{V}$ was elected to the papacy. Clement $\mathrm{V}$ was intellectually capable, but was also meek when it came to dealing with the French throne. Clement V's lack of aggression in a political sense can be said to have caused the end of the medieval papacy. 
The second set of words is clearly a paraphrase of the first set. ${ }^{250}$ Even if the trier of fact believes that the facts contained in author $X$ 's writing are per se noncopyrightable, the factfinder will still have to determine whether the expression contained in the second work infringes a copyright in the expression contained in the first. If the factfinder applies the standard theory of infringement urged by the commentators and applied by some courts, the minor changes in the second are likely to be considered "immaterial variations." ond paragraph would probably be considered substantially similar to the first under either the "abstractions test" or the "patterns test."

To a very limited degree, the case law ${ }^{253}$ and Professor Nimmer ${ }^{254}$ support the view that there should be a different standard for the infringement of protectible expression when factual works are involved: "[I]f the only original aspect of a work lies in its literal expression, then only a very close similarity, verging on the identical, will suffice to constitute an infringing copy."265 Some courts have held that when a work is based on material in the "public domain," the standard for infringement is not the same, and "small variations" in the subsequent work may protect it from charges of infringement. ${ }^{256}$ The difficulty with this view is that ideas are also in the public domain, yet small variations in the expression of ideas are insufficient to allow a subsequent user of the ideas to escape liability for infringement. ${ }^{28 z}$ The reason that a different standard of infringement is required for factual works is not, as those authorities maintain, that facts are in the public domain, but that there are only a limited number of ways in which facts can be expressed.

One recent case that recognizes that this practical limitation requires a different standard of infringement is Landsberg $v$. Scrabble Crossword Game Players, Inc. ${ }^{258}$ In Landsberg, the plaintiff, "the acknowledged Scrabble champion of Southern California," wrote a man-

${ }^{250}$ At this point, I am referring only to paraphrasing of discrete facts.

251 Nichols v. Universal Pictures Corp., 45 F.2d 119, 121 (2d Cir. 1930), cert. denied, 282 U.S. 902 (1931).

232 See supra note 113.

${ }^{25 s}$ See, e.g., Deering Milliken, Inc. v. Quaker Fabric Corp., 187 U.S.P.Q. (BNA) 288, 290 (S.D.N.Y. 1975).

254 See 3 M. NIMMER, supra note 73, at $\S 13.03$ [A][1].

255 Id.

${ }^{258}$ See Concord Fabrics, Inc. v. Generation Mills, Inc., 328 F. Supp. 1030, 103233 (S.D.N.Y. 1971); Lauratex Textile Corp. v. Citation Fabrics Corp., 328 F. Supp. 554, 556 (S.D.N.Y. 1971).

287 Although facts and ideas are both in the public domain, it is easier to identify a fact than it is to distinguish an idea from its expression. The difficulty with this argument is that it begs the question of how to define factual "expression."

258736 F.2d 485 (9th Cir.), cert. denied, 105 S. Ct. 513 (1984). 
uscript on Scrabble strategy and sent it to Scrabble for evaluation. ${ }^{259}$ Scrabble reviewed the manuscript, found it to be excellent, and entered into negotiations with Landsberg. The district court found that these negotiations were in bad faith and calculated to delay for time so that Scrabble could prepare its own strategy handbook based on Landsberg's manuscript. ${ }^{280}$ The district court also found that Scrabble had kept copies of Landsberg's manuscript for its own purposes after Landsberg demanded that Scrabble return or destroy its copy of the manuscript, and that Scrabble had paraphrased a substantial part of Landsberg's manuscript. ${ }^{261}$

On appeal, the court of appeals reversed the district court's finding of an infringement:

One consequence of the policy in favor of free use of ideas is that the degree of substantial similarity required to show infringement varies according to the type of work and the ideas expressed in it. Some ideas can be expressed in myriad ways, while others allow only a narrow range of expression. Fictional works generally fall into the first category. The basic idea of a fictional work might be that classic, boy meets girl. This idea can be expressed, as it has been through thousands of years of literature, with infinite variations in setting, sequence of incident, and characterization. ...

Factual works are different. Subsequent authors wishing to express the ideas contained in a factual work often can choose from only a narrow range of expression. ${ }^{262}$

The court provided an example of this principle. Landsberg's manuscript contained a statement that "[ $t]$ he poor player simply attempts to make as many points as possible each turn."263 The court observed that given the limited number of ways in which the factual idea could be expressed, "[j]ust about any subsequent expression of that idea is likely to appear to be a substantially similar paraphrase of the words with which Landsberg expressed the idea."264

250 Id. at 486.

280 See id. at 487.

${ }^{281}$ See id. Landsberg stated a cause of action under common-law copyright and under the copyright statute, because the alleged infringements occurred at different times. Although state law would apply to the former claim and federal law to the latter, the district court held that this distinction could be disregarded because California appeared to follow federal copyright cases on the issue of infringement. See id.

${ }^{262}$ Id. at 488 (citation omitted).

263 Id.

264 Id. 
The holding in Landsberg reflects a general copyright doctrine that when there is a merger or near merger of idea and expression, to prohibit free use of the expression would be tantamount to granting a monopoly on the use of the idea. ${ }^{265}$ Although the merger doctrine is applicable to both factual and fictional works, it has particular relevance to factual works because there are limited ways of expressing

265 It would be inaccurate to say that Landsberg is a completely unambiguous instance of the merger of idea and expression. According to the merger doctrine, if a merger of idea and expression existed, then Scrabble should have been able to use Landsberg's expression verbatim. Although that issue was not presented in the case, see id. at 487 , dicta in the opinion suggest that the court believed that Scrabble could not have used verbatim expression. See id. at 488-89.

There are five separate strands of the merger doctrine. The first is exemplified by cases in which the expression and the idea are so inextricably interwoven that the idea "dictates" the sole form of expression. See, e.g., Baker v. Selden, 101 U.S. 99, 104-05 (1879); Herbert Rosenthal Jewelry Corp. v. Kalpakian, 446 F.2d 738, 742 (9th Cir. 1971). The second strand is exemplified by cases in which the idea permits little variation in expression and there is some variation of actual expression between the two works. See, e.g., Continental Casualty Co. v. Beardsley, 253 F.2d 702, 706 (2d Cir.), cert. denied, 358 U.S. 816 (1958); Crume v. Pacific Mut. Life Ins. Co., 140 F.2d 182, 184 (7th Cir.), cert. denied, 322 U.S. 755 (1944). In Crume, relied on in Beardsley, the court insisted, "To hold that an idea, plan, method or art described in a copyright is open to the public but that it can be used only by the employment of different words and phrases which mean the same thing, borders on the preposterous." 140 F.2d at 184-85.

In the third strand of the merger doctrine, typified by Morrissey v. Procter \& Gamble Co., 379 F.2d 675, 678-79 (1st Cir. 1967), the idea can be expressed in only a limited number of ways and there is no variation of actual expression between the two works. The fourth strand, to which Landsberg belongs, allows copying of scenes a faire, expression that constitutes "stock scenes or scenes that [flow] necessarily from common unprotectable ideas,' . . . because to hold otherwise would give the first author a monopoly on the commonplace ideas behind the scenes a faire." Landsberg, 736 F.2d at 489 (quoting See v. Durang, 711 F.2d 141, 143 (9th Cir. 1983)); see also Rehyer v. Children's Television Workshop, 533 F.2d 87, 92 (2d Cir.) (copyrighted children's book not infringed by a magazine story containing a similar theme, in part because "where a lost child is the protagonist, there is likely to be a reunion with parents"), cert. denied, 429 U.S. 980 (1976). The fifth strand involves copying of stereotyped phraseology. See, e.g., Oxford Book Co. v. College Entrance Book Co., 98 F.2d 688, 691 (2d Cir. 1938).

William Patry argues that there is a difference between merger "that denies, ab initio, copyright protection to a work and that type of merger that does not deny copyrightability, but that operates as a limitation on the scope of protection." Patry, supra note 22 , at 652 . Patry also claims that failure to distinguish between these two types of merger results in the wrongful appropriation of protectible expression. According to Patry, any concern for the free use of ideas and access to information should be accommodated by the noncopyrightability of facts and ideas and not by considering merger in the infringement context. See id. at 652-53.

As a practical matter, however, Patry's distinction is irrelevant. Both types of merger that Patry describes would be resolved at the infringement stage on the ground that substantial similarity cannot be found if true merger exists. In particular, the type of merger that denies copyrightability is considered at the infringement stage because the prohibition on the copyrightability of ideas and fact contained in 17 U.S.C. $\S 102(b)(1982)$ is given effect at the infringement stage. See 1 M. NIMMER, supra note 73 , at $\S 2.03[D]$. 
facts, which are per se noncopyrightable. ${ }^{286}$ The merger doctrine strongly militates in favor of the position that when factual works are involved courts should allow liberal use of expression and should forego using infringement standards applicable to fictional works. Recognition of the importance of the merger doctrine for factual works must be an essential part of the standard of infringement in cases involving such works.

It has been argued, however, that there are "stylistic variations available for recounting most factual tales." least three difficulties, depending on how it is understood. First, if the proposition is that the ideas contained in factual information can be expressed in different ways, then the proposition fails to recognize that facts, as well as ideas, are in the public domain. Although it is true that the idea of the relationship between Clement $\mathrm{V}$ and the medieval papacy can be expressed in many ways, this idea is not the only thing in the public domain - the actual or hypothesized facts concerning Clement $\mathrm{V}$ are also in the public domain. If one of these facts is that "Clement $\mathrm{V}$ was regarded as an able intellectual, but was timid, and was very subservient to the French throne," then although the abstract idea-Clement V's intellectual capability and character disposition-can be expressed in many ways, the fact that Clement V was regarded as intellectually able but was timid cannot be conveyed by a wide variety of expressions.

Second, if the proposition is that, at least with certain factual works-most notably historical or biographical narrative-there are always different ways in which concrete factual assertions can be paraphrased, then it would seem that the proposition exalts form over substance. The proposition acknowledges that the factual assertions and not just the ideas are in the public domain, yet insists that the subsequent user vary the assertion within the strict logical limits imposed by

286 The copyright statute provides an ostensible exception to the "merger" rule for a "compilation," defined as "a work formed by the collection and assembling of preexisting materials or of data that are selected, coordinated, or arranged in such a way that the resulting work as a whole constitutes an original work of authorship." 17 U.S.C. $\S 101$ (1982); see also id. $\S 103$ (limiting copyright protection in compilations "to the material contributed by the author of such work, as distinguished from the preexisting material employed in the work"). In compilation cases, even though the idea and expression may merge-there are only so many ways to express a telephone directory-the resulting collection of facts is protectible. The extent of protection in such cases, however, is uncertain. Compare Triangle Publications v. Sports Eye, Inc., 415 F. Supp. 682 (E.D. Pa. 1976) (holding that data in a horseracing chart could be used in a subsequent compilation) with Leon v. Pacific Tel. \& Tel. Co., 91 F.2d 484 (9th Cir. 1937) (holding that a directory with sequential telephone numbers infringed the copyright in an existing alphabetical directory).

287 Gorman, supra note 3, at 593. 
the nature of that information.

Third, if the proposition is understood as asserting that the bare fact is in the public domain, but that the arguments or theories in support of this fact are not in the public domain, ${ }^{268}$ there is no logicai reason to draw such a line. For example, if the bare fact acknowledged to be in the public domain is that Clement $\mathrm{V}$ was timid, and the historian's argument in support of that fact is that Clement $V$ was subservient to the French throne, there is no reason to maintain that the premise-itself a factual assertion that gives rise to the conclusion about Clement V's character-is protectible while the conclusion is not. There are, of course, hypotheses like "Clement V's timid disposition was caused by the economic and social conditions extant during his childhood," whose truth or falsity will be difficult to determine. Nevertheless, even this type of assertion can, at least in theory, be proved or disproved, and can have evidence marshalled for or against it.

The implication of applying the merger doctrine to factual works is that the authors of such works may receive protection only against exact or nearly exact copying, a consequence that may be difficult to accept in the face of the admittedly considerable time, effort, and creativity that characterize the production of many factual works. Nevertheless, copyright law protects "writings" and cannot constitutionally protect labor or effort divorced from those writings. ${ }^{269}$

\section{Conflation of Infringement and Fair Use}

Sometimes a court will recognize that idea or fact merges with expression in that according protection to the expression is tantamount to according protection to the unprotectible idea or fact contained in the expression. Nevertheless, the court may find an infringement under the traditional standard of substantial similarity, and fail to consider the import of the merger of fact or idea with expression until it analyzes whether there has been a fair use.

This approach, which some commentators support, ${ }^{270}$ is unsound for two reasons. First, the fair use doctrine generally assumes that there would be an infringement absent the fair use privilege; however, if there is a merger of idea or fact with expression, then use of the expression cannot constitute infringement, thus precluding the need to en-

${ }^{268}$ See Ginsburg, supra note 22, at 670; Patry, supra note 22, at 654-55.

${ }^{268}$ See $1 \mathrm{M}$. NIMMER, supra note 73 , at $\S 2.10[\mathrm{E}]$. But see Denicola, supra note 22 , at $519-20$.

270 See Denicola, supra note 22, at 541; Ginsburg, supra note 22, at 670-71; Gorman, supra note 3, at 594; Patry, supra note 22, at 652 . 
gage in fair use analysis. Second, this approach has distinct totality overtones. If the merger is considered merely a factor in fair use analysis, then even though the court may conclude that merger exists, it may nevertheless find that there is no fair use as a result of the ad hoc balancing of equitable factors, unrelated to infringement, required by the fair use doctrine. A fair use decision against the defendant could result in according copyright protection at the fair use stage to what should have been declared unprotectible at the infringement stage. This problem is exemplified by three recent cases, including the Supreme Court's opinion in The Nation.

In deciding the fair use issue in The Nation, the Court reviewed each statutory factor in assessing the verbatim quotations used by Navasky. When the Court focused on the nature of the copyrighted work it noted, "Some of the briefer quotes from the memoir are arguably necessary adequately to convey the facts; for example, Mr. Ford's characterization of the White House tapes as the 'smoking gun' is perhaps so integral to the idea expressed as to be inseparable from it."271 Whether some of the briefer quotes presented a merger-type problem is a secondary issue; what matters is that the Court assumed that it was proper to analyze the issue of merger under the fair use rubric. If there is a true merger of fact and expression, then the use of the merged material, however similar to the original, cannot be an infringement because the merged material is not copyrightable. But the Court assumed that any use of the verbatim language, whether merged with facts or not, would constitute infringement unless excused by fair use. The Court examined the verbatim quotations under a fair use analysis when the merged portions should never have gotten past the substantial-taking portion of the infringement analysis.

A recent Second Circuit case illustrates an interesting variation of this form of the totality approach. In Eckes $v$. Card Prices Update, ${ }^{272}$ the plaintiffs spent a great amount of time preparing a guide containing lists of baseball cards together with their going market prices. The defendant published a monthly update of card prices and included a listing very similar to the plaintiffs' listing of 5,000 "premium cards," including certain errors that appeared in the plaintiffs' listing. ${ }^{273}$ The district court held that although there were "marked similarit[ies]" between the two lists, these similarities may have derived from the fact that the plaintiffs' list was so influential that it determined market prices, so that "any subsequent publication accurately reflecting which

271105 S. Ct. at 2232.

272736 F.2d 859 (2d Cir. 1984).

273 See id. at 861 . 
cards are being traded at a premium would, of necessity, bear strong similarities to the plaintiffs' work."274 The court of appeals reversed, holding, inter alia, that although there was no credible evidence in the record showing that the plaintiffs' guide did in fact establish market prices, any similarity based on such establishment "would best be advanced in a fair use context."276 The difficulty with this position is that if the plaintiffs' guide did establish the market price, then there could be no difference between the idea of a guide listing market prices and the expression of that idea in the plaintiffs' guide. In such a case, any similarity between the plaintiffs' guide and a subsequent list would be inevitable; there should be no need to venture beyond the infringement stage into fair use. ${ }^{270}$

Eckes relied on an earlier case, Consumers Union of the United States, Inc. v. General Signal Corp., ${ }^{277}$ in which the court of appeals held, in the context of a fair use analysis involving merger concerns, that "[w]here an evaluation or description is being made, copying the exact words may be the only valid way precisely to report the evaluation."278 The "evaluation or description" at issue in Consumers Union was a factual assertion concerning the results of tests on a product conducted by Consumers Union. Whether application of the merger concern was appropriate in this context is irrelevant. ${ }^{279}$ What is clear,

${ }^{274}$ Eckes v. Suffolk Collectables, 575 F. Supp. 459, 464 (E.D.N.Y. 1983), rev'd, 736 F.2d 859 (2d Cir. 1984).

278736 F.2d at 864.

278 In Eckes, the court rejected the argument that a baseball card price compilation could not be copyrighted because copyright protection did not extend to the idea of the compilation or to the facts contained therein. See id. at 862-63. Eckes involved a nearly complete reproduction of a portion of the copyrighted compilation. Thus, the court refused to "dissect" the compilation into protectible and unprotectible elements. See id. To allow dissection in this or any other compilation case in which the idea and structure of the compilation are dictated by the underlying substance would deny copyright protection to the compilation entirely, yet it is accepted that compilations deserve some protection. See supra note 266. It is incorrect to conclude, however, that the exception for compilations "may also be significant for . . . nonfiction narratives" because dissection "facilitates disregard of the subjectivity and creativity the author brings to the combination of separately unprotectible elements." Ginsburg, Copyright Law: Fact Works Revisited, N.Y.L.J., July 19, 1984, at 22, col. 3.

277724 F.2d 1044 (2d Cir. 1983).

278 Id. at 1049-50 (citing Morrissey v. Procter \& Gamble Co., 379 F.2d 675, 67879 (1st Cir. 1967)).

${ }^{279}$ It appears, nevertheless, that the court did apply the merger doctrine correctly. There are a very limited number of ways in which the information that Consumers Union provided about products can be expressed. For example, Consumers Union had originally stated that "only one model, the check-rated Regina Power Team, was an adequate substitute for a full-sized vacuum." $724 \mathrm{~F} .2 \mathrm{~d}$ at 1047 . It should be noted that Consumers Union objected to any use of its name, as well as its information, in advertising any product, and would probably have objected even if the defendant had not quoted directly. See id. at 1046. 
however, is that if a factual assertion is so "integral to the idea expressed as to be inseparable from it," then any similarity based on that assertion should be considered in making a determination of infringement. Accordingly, the issue should not be resolved at the fair use stage.

The merger theory reflects the notion that when idea and expression are inseparable, the subsequent user needs to be able to use the expression in order to use the idea. Although the determination of whether a merger exists should not depend on whether the factfinder determines that the use is fair, fair use still plays some role when the argument is made that use of another's expression is necessary to portray an idea accurately. For instance, in writing a scholarly treatise on photography, an author may need to use copyrighted photographs in order to be "accurate." In this case, there is clearly infringement, and fair use becomes the proper rubric under which to analyze whether the use should be allowed. This "necessity," however, differs from the necessity involved in true merger situations. In the former, there is no "merger" of idea and expression, merely the desire to use both together in order to ensure accuracy. ${ }^{280}$ It is dangerous to consider editorial or

${ }^{280}$ See, e.g., Meeropol v. Nizer, 560 F.2d 1061, 1069 (2d Cir. 1977), cert. denied, 434 U.S. 1013 (1978). Professor Nimmer bases his limited first amendment defense to copyright infringement on this type of "necessity," but unfortunately appears to confuse it with true merger. See $1 \mathrm{M}$. Nimmer, supra note 73, at $\S 1.10[\mathrm{G}][2] ; \mathrm{M}$. NimMER, NIMMER ON FREEDOM OF SPEECH § 2.05[G][2] (1984). A very similar view is presented in Denicola, supra note 22, at 523-24. Under Professor Nimmer's thesis, when the expression (as opposed to the idea) is necessary and meaningful to the democratic dialogue, then subsequent use would be permitted under a compulsory license. See 1 M. NIMMER, supra note 73, at § 1.10[c][2]. The "necessity" invoked by Nimmer is necessity for first amendment purposes, not for copyright purposes. For first amendment purposes, expression may be needed to facilitate conveying an idea. On the other hand, for copyright purposes the true merger of idea and expression necessitates denying copyright to an expression of an idea for fear of granting a monopoly on the idea. This first amendment defense is limited by Professor Nimmer's acceptance of the first amendment as protecting a self-governing people's participation in the marketplace of ideas. A different first amendment theory might result in a much broader privilege based on speech necessary to serve other first amendment concerns. See, e.g., Baker, Scope of the First Amendment Freedom of Speech, 25 UCLA L. REv. 964 (1978).

Professor Gorman also has confused the two types of necessity. In discussing Rosemont Enters. v. Random House, Inc., 366 F.2d 303 (2d Cir. 1966), cert. denied, 385 U.S. 1009 (1967), he comments that the court looked, inter alia, to whether the preparation of the subsequent work " 'require[d] some use of prior materials dealing with the same subject matter.' " Gorman, supra note 3, at 597 (quoting Rosemont, 366 F.2d at 307). He concludes that this factor is no more than a restatement of the doctrine of merger of fact and expression. The "need" referred to in Rosemont, however, was a first amendment consideration, not a "merger" consideration. The court was concerned with a subsequent use needed to convey an idea, not a need to guard against monopolization of the idea.

Professor Ginsburg argues that necessity should be considered at the fair use stage. See Ginsburg, supra note 22, at 670-72. The "necessity" to which she refers as a fair use consideration is not necessity based on merger, but necessity based on accuracy or 
artistic "need" to use the original as presenting a true merger problem.

If, however, the idea or fact is logically or practically inseparable from the factual expression, then it is appropriate to resolve the issue at the infringement stage in favor of no substantial similarity, at least with respect to that portion of the original expression that is merged. For example, if the "evaluation or description" referred to in Consumers Union was Jane Eyre's description of Mr. Rochester, then it would be inaccurate to say that a true merger problem was presented; thus, whether the use of the description constitutes infringement should properly be determined under fair use. Conversely, if the "evaluation or description" is a factual assertion-that Ford characterized the White House tapes as the "smoking gun"--then a merger problem may arise because Ford's utterance is at least arguably a fact that cannot otherwise be expressed without the use of the verbatim language. In this case, the problem should not be relegated to the uncertain balancing of fair use, but should be decided as a matter of law at the infringement stage. To do otherwise would permit factfinders to use the multiple criteria of fair use inquiry to accord protection to essentially unprotectible material. This excessive protection would frustrate a basic goal of copyright law because "the risk of restraining the free flow of information is more significant with informational work."281

\section{Totality Analysis and "Wholesale Usurpation" of Expression}

The third version of totality analysis involves the extraordinarily complex and confused notion in copyright jurisprudence that the defendant may not engage in what is characterized as a "wholesale usurpation" or "bodily appropriation" of protected material. For example, in Hoehling v. Universal City Studios, ${ }^{282}$ the Second Circuit stated that " " $t]$ here cannot be any such thing as copyright in the order of presentation of the facts, nor, indeed, in their selection," "283 and absent

convenience. As an example of necessity, she cites Time, Inc. v. Bernard Geis Assocs., 293 F. Supp. 130 (S.D.N.Y. 1968), which held that the merger doctrine of Morrissey v. Procter \& Gamble Co., 379 F.2d 675 (1st Cir. 1967), did not apply to the defendant's use of photographs of the Kennedy assassination, but that the public interest weighed in favor of the use. See Ginsburg, supra note 22, at 671-72 (referring to Geis, 293 F. Supp. at 143, 146).

${ }^{281}$ Consumers Union, 724 F.2d at 1049.

282618 F.2d 972 (2d Cir.), cert. denied, 449 U.S. 841 (1980).

${ }^{283}$ Id. at 978 (quoting Myers v. Mail \& Express Co., 36 Copyright Office Bull. 478, 479 (S.D.N.Y. 1919) (L. Hand, J.)). Professor Ginsburg has criticized the Hoehling court's reliance on Myers on the ground that Judge Hand's statement was dictum and that Judge Hand "indicated merely that conventional chronological organization was not subject to copyright." Ginsburg, supra note 22, at 653-54 (footnote omitted). In contrast to "conventional chronological organization," Professor Ginsburg 
"wholesale usurpation of a prior author's expression," claims of infringement for factual works should not be upheld. ${ }^{284}$ Copyright scholars have criticized the doctrine of wholesale usurpation on the ground that it unjustifiably serves as an alternative to the substantial similarity standard of infringement; that is, under the doctrine a subsequent use of a factual work constitutes infringement only if the use amounts to a wholesale usurpation of the literal expression contained in the prior work, not merely if the subsequent product is substantially similar to the prior work. ${ }^{286}$

The traditional understanding of the wholesale usurpation doctrine criticized by the commentators is probably incorrect in that it ignores the fact that the doctrine appears in at least three different versions. Moreover, none of these versions seems to imply that a subsequent use of factual information can constitute infringement only when the user engages in a wholesale appropriation of literal expression.

Under the first version, a subsequent user may not engage in a wholesale usurpation of the fruits of a prior author's research or labor. ${ }^{288}$ There is some confusion about whether all or only some of these

offers

an historian's choice and exploitation of setting or elucidation of scenes . . . analogous to a playwright's development of dramatic structure. Thus, for example, to commence a history of World War I at the 1910 funeral of Edward VII, thereby capturing the old socio-political order, and highlighting the ominousness of German expansionism, demonstrates an evocation and an artistry warranting copyright protection.

Id. at 649 (footnote omitted).

Two responses to Professor Ginsburg's argument are in order. First, Professor Ginsburg fails to recognize that Judge Hand in Myers explicitly acknowledged that selection of facts is not protectible "although into that selection may go the highest genius of authorship, for indeed, history depends wholly upon a selection from the undifferentiated mass of recorded facts." 36 Copyright Office Bull. at 479 . Surely, Judge Hand's statement covers the historian's decision to begin the history at the funeral of Edward VII, a decision that may reflect great genius on the part of the historian after sifting through the undifferentiated mass of facts possibly relevant to World War I. The point is that it is incorrect to think that Judge Hand was speaking only about chronological rather than "socio-political" or other histories.

Second, in focusing on Myers, Professor Ginsburg neglects other cases that support the Hoehling court. See, e.g., Oxford Book Co. v. College Entrance Book Co., 98 F.2d 688, 691 (2d Cir. 1938) (arguing that with respect to historical works "[t]he subject matter is of necessity what events have made it and the order of treatment whether that be chronological or topical is fixed by the facts") (emphasis added); Fuld v. National Broadcasting Co., 390 F. Supp. 877, 882 (S.D.N.Y. 1975) (asserting that historical facts are in the public domain and available to any writer who wishes to use them).

284 See Hoehling, 618 F.2d at 980.

28s See Denicola, supra note 22, at 539; Ginsburg, supra note 22, at 648; Gorman, supra note 3, at 593.

${ }^{288}$ See infra notes $289-312$ and accompanying text. 
fruits must be appropriated before the taking becomes infringement. Protection of labor and research clearly represents a totality analysis because such protection is tantamount to according copyright protection to the facts discovered as a result of the research or labor.

According to the second version, there can be no fair use of a factual work if the use constitutes a wholesale usurpation. ${ }^{287}$ In this instance, the doctrine is not one that establishes a standard for infringement, but one that becomes relevant only after infringement has been established. This second version of the doctrine may also constitute totality analysis if courts use it to accord broad copyright protection to factual material and then "compensate" by substituting the wholesale usurpation standard as a fair use factor.

The third version of the doctrine involves essentially an additional type of protectible expression reflected in the total structure and arrangement of the work, distinct from the literal expression contained in the work. ${ }^{288}$ This version of the wholesale usurpation doctrine also raises totality concerns; if disparate facts can be paraphrased, but total structure and arrangement-the "mosaic"-cannot be imitated, then collections of noncopyrightable facts may receive some level of copyright protection.

It is, of course, somewhat artificial to present these versions as completely or clearly distinct. If such designations could be made so readily, there would not be as much confusion in the cases and academic comment concerning the wholesale usurpation doctrine. This confusion has been manifested not so much in disagreement among different courts-indeed, most of these cases have arisen in the Second Circuit-as in instances in which different versions of the doctrine have been confused within the same opinion, or in which one version has been discredited only to reappear later under a different characterization. Understanding the doctrine of wholesale usurpation and the relationship of the doctrine to totality analysis requires a rather tortuous journey through a number of cases that have, for the most part, been neglected as paradigms for the doctrine. In this portion of the Article, I analyze the development of each version of the doctrine, contrasting in particular my position with Professor Denicola's. I conclude that the first two versions of the doctrine seriously conflict with the basic purposes of copyright law. The third version, articulated by the court of appeals in The Nation, presents a closer question. 


\section{Wholesale Usurpation of Research or Labor}

The first version of the wholesale usurpation doctrine is that there may be no wholesale usurpation of the "fruits of labor" of a prior author. If this version of the doctrine is understood to prohibit use of an author's research, then the doctrine is clearly a totality approach, because protection of research or labor is tantamount to protecting the facts found by that research or labor. The contours of this version of the doctrine are established by several cases.

In Huie v. National Broadcasting Co., ${ }^{289}$ defendant Meree Miller read the plaintiff's story, entitled The Hero of Iwo Jima, concerning the tragic life of one of the marines in the staged photograph of the raising of the American flag on Mt. Suribachi. He then prepared a television script similar to the plaintiff's story. The plaintiff filed an action against Miller and a number of other defendants, seeking a preliminary injunction against broadcast of the film based on the script. The court recognized the historical nature of the work, but argued that this characteristic was not dispositive:

For example, if an historian had published a history of the negotiations between the Soviet Union and the United States with respect to nuclear explosions and copyrighted it, it would be an infringement of the copyright for another historian to publish a history re-written from the first historian's book without any independent research. The stock example is the city directory which publishes nothing but facts but which cannot be copied without infringing its copyright. The second historian or second directory publisher cannot bodily appropriate the research of his predecessor. ${ }^{200}$

The court noted that Miller had used certain fictional episodes in the plaintiff's work without conducting independent research, but held that this behavior was insufficient to show that he had "bodily appropriated" the plaintiff's research. ${ }^{291}$ The court stated that "[ $\left.t\right]$ he determining question must be . . . whether defendant Miller has appropriated plaintiff's literary treatment of 'historical' facts."282 This question presumably focused on whether Miller had unlawfully appropriated the plaintiff's protectible expression.

The court held that although there was no allegation that Miller

289184 F. Supp. 198 (S.D.N.Y. 1960).

290 Id. at 200.

201 See id.

282 Id. 
had copied from the plaintiff in a "slavish" manner, an inquiry into appropriation of expression included determining whether the plaintiff's literary treatment "was of such originality that [the court] must say that defendants' treatment of the same subject was inspired by it." ${ }^{293}$ Miller had considered preparing the television script before he saw the plaintiff's story, and once he had the historical data, the theme that he followed was said to be "almost inevitable."

Huie is a curious case. There was no doubt that Miller "copied" the plaintiff's work. He acknowledged that he read the plaintiff's story, and the court noted that he had removed, on the plaintiff's request, " $a$ number of verbal similarities" from the penultimate version of the television script. ${ }^{295}$ Further, the plaintiff's fictional episodes embedded in the biographical account were evident in Miller's work. The court could have relied on Oxford and held, as the defendants urged, that any similarity between the works based on information in the public domain (including "misinformation" masquerading as historical fact) was not a basis for finding infringement. Instead, the court viewed the noncopyrightability of fact as relevant only after it examined the works to see whether Miller had "bodily appropriated" the plaintiff's research without conducting independent research. ${ }^{286}$ This inquiry was confused, however, because the court recognized that Miller had not conducted independent research in appropriating the "fictional" elements of the plaintiff's work. This analysis suggests strongly that the court would have found the required appropriation only if all or substantially all of the first work had been taken by the second author. ${ }^{297}$

Once the court determined that there had been no "bodily appropriation," it turned to the issue of appropriation of expression, which involved a two-pronged inquiry into whether the expression was "slavishly" copied and whether it was so original that it "inspired" the defendants' version. ${ }^{298}$ Here, the court seemed to recognize the Oxford principle that when a work focuses on historical facts, similarities in the treatment of the same event or set of events by the two authors are inevitable and cannot form the basis for a finding of copyright infringement.

The strict bodily appropriation standard of Huie was relaxed sig-

203 Id.

204 Id.

205 See id. at 199.

206 See id. at 200.

207 Indeed, the court noted that the case was different from its example of a book describing the history of nuclear weapons negotiations. In that example, "all of the facts" were copied when the court found "bodily appropriation." See id.

208 See id. 
nificantly by Orgel v. Clark Boardman Co. ${ }^{299}$ in which the court of appeals affirmed a finding of infringement by the same judge who decided Huie. In Orgel, the defendant published a law treatise on eminent domain valuation and procedure. The district court determined that approximately thirty-five percent of the defendant's treatise infringed the plaintiff's treatise, although it did not indicate the percentage of the plaintiff's work that the defendant appropriated ${ }^{300}$ The court of appeals, in affirming the district court's finding of infringement, held that the defendant had "lifted" the essence of the plaintiff's work: although he added additional material and went beyond the plaintiff's work, he adopted the plaintiff's "analysis, organization of material, phrasing and citations without any credit to" the plaintiff. ${ }^{301}$ The court recognized that although two treatises on the same legal subject were bound to be similar because of stock phraseology and common sources, this inevitable "innocent similarity" was exceeded by the defendant's "colorable variation" of the plaintiff's work. ${ }^{302}$ The court concluded by stating that "[a]ppropriation of the fruits of another's labor and skill in order to publish a rival work without the expenditure of the time and effort required for independently arrived at results is copyright infringement."303

Orgel neglected entirely any determination of whether the similarity between the works was predicated on noncopyrightable information. Rather, the court based its finding of unlawful appropriation on a comparison of the complete texts. ${ }^{304}$ In addition, the court did not use the same standard for "bodily appropriation" as did the district court in Huie. In Huie, the court suggested that "bodily appropriation" meant that the defendant would have to appropriate all or substantially all of the plaintiff's work. In Orgel, the court relied exclusively on a determination of whether the defendant had appropriated the "fruits of [the plaintiff's] labor" without independent research. ${ }^{305}$ Related to the

290301 F.2d 119 (2d Gir. 1962).

${ }^{300} \mathrm{See}$ id. at 122. A comparison of the two works at issue suggests that the defendant appropriated only selected portions of the plaintiff's treatise. Compare A. JaHR, LAW OF EMINENT DOMAIN (1953) with L. ORGEL, VALUATION UNDER THE LAW OF EMinent Domain (1936).

${ }_{301}$ Orgel, 301 F.2d at 120.

${ }^{302}$ Id. (footnote omitted).

${ }^{303} I d$. (footnote omitted). As support for this proposition, the court cited an earlier case that dealt not with the copyrightability of factual information, but with the fair use of syllabuses accompanying reported law cases. See id. (citing West Publishing Co. v. Edward Thompson Co., 176 F. 833 (2d Cir. 1910)). Even in West, the court suggested that different types of factual works would receive different levels of protection under the fair use doctrine. See West, $176 \mathrm{~F}$. at 838 .

sot See Orgel, 301 F.2d at 120.

sor See id. 
court's neglect of copyrightability analysis and its expanded view of "bodily appropriation" based on appropriation of the fruits of labor was the court's assumption that the "innocent similarity" that would inevitably exist between two factual works dealing with the same subject matter could not exceed the level of similarity that would result from the independent use of common phraseology and sources. Similarity that would inevitably result from the defendant's use of the noncopyrightable portions of the plaintiff's work was not considered..$^{306}$

Although Huie and Orgel differ in the amount of wholesale usurpation necessary to establish a copyright infringement, it is clear that both cases rest on the theory that a subsequent author may not appropriate the fruits of a prior author's labor without independent research. ${ }^{307}$ Neither case, however, reflects the clear trend of judicial de-

${ }^{308}$ With regard to "innocent similarity" the court cited Chautauqua School of Nursing v. National School of Nursing, 238 F. 151 (2d Cir. 1916). In Chautauqua, the plaintiff alleged that the copyright in its photograph-illustrated publication dealing with the administration of hypodermic injection was infringed by the defendant's publication dealing with the same subject. The court conceded that the plaintiff was the first to produce a text in which hypodermic injection was divided into the 12 successive stages generally practiced in medicine, as well as the first to illustrate each stage with a photograph. See id. at 152. The court ruled, however, that the plaintiff "had no monopoly of the things taught in its [text], because they were the common teaching." Id. at 153. The author of the defendant's publication, a physician, "had a right to consult all previous publications on the subject . . . and to state in his own language what he thought to be the proper and the best practice." Id. The court analogized the work in question to a directory, a dictionary, a guide for railroad trains, and a guide for automobile trips. The court also cited a treatise arguing that the requirement of originality in copyright law demanded only that the subsequent author " be the producer of that for which he claims protection," id. (quoting E. DRONE, A TREATISE ON THE LAW of Property in Intellectual Productions in Great Britain and the UNITED STATEs 205 (1879)), to support its ruling that "[i]n such cases the question is whether the writer has availed himself of the earlier writer's work without doing any independent work himself." Id. The court also held that the defendant's photographs did not infringe the plaintiff's copyright in the photographs because the defendant took his own pictures of the procedures and did not reproduce the plaintiff's photographs. See id. at 152.

The point here is that although the court imposed the requirement that the defendant engage in "independent work," it is clear from the opinion that all that was required was that the defendant did not copy the plaintiff's work so as to preclude a finding of originality in the second work. That is, if the defendant had read the plaintiff's work and no other, and had stated his own conclusions in his own language, then the defendant's text would be an independent work.

${ }^{307}$ As explained in the section concerning the second version of the wholesale usurpation doctrine, the labor theory of copyright resurfaced in modified form in Wainwright Sec. Inc. v. Wall St. Transcript Corp., 558 F.2d 91 (2d Cir. 1977), cert. denied, 434 U.S. 1014 (1978). See infra notes 329-32 and accompanying text. This fact is somewhat puzzling in light of the earlier rejection of the theory by the same court in Rosemont Enters. v. Random House, Inc., 366 F.2d 303 (2d Cir. 1966). Rosemont had rejected the theory as it was embodied in Toksvig v. Bruce Publishing Co., 181 F.2d 664 (7th Gir. 1950). See 366 F.2d at 310. The court in Toksvig found infringement based on a use of "general concepts" concerning the life of Hans Christian Andersen, 
cisions toward recognition that labor or research is simply not protectible under the copyright law or the first amendment. ${ }^{308}$ As the Fifth Gircuit asserted:

The valuable distinction in copyright law between facts and the expression of facts cannot be maintained if research is held to be copyrightable. There is no rational basis for distinguishing between facts and the research involved in obtaining facts. To hold that research is copyrightable is no more or no less than to hold that the facts discovered as a result of research are entitled to copyright protection. ${ }^{309}$

Further, it makes no difference if all (Huie) or only some (Orgel) of the fruits of labor are appropriated. The copyright law may constitutionally protect only the writings of authors and not their labor. Insofar as copyright law is concerned, it makes no difference whether the subsequent author takes all, substantially all, or only some of the labor of the prior author.

In a recent article, Professor Denicola argues to the contrary that "[t]he effort of authorship can be effectively encouraged and rewarded only by linking the existence and extent of protection to the total labor of production."310 Although Professor Denicola may be correct in maintaining that his scheme would be more "effective" in encouraging research, his theory relies on the mistaken view that copyright rests, at least in part, on "[n]otions of a natural right to the fruits of one's labor." 111 It is clear that copyright is merely "a means by which an important public purpose may be achieved. It is intended to motivate the creative activity of authors and inventors by the provision of a special reward ...."312

\section{Wholesale Usurpation and Fair Use}

The second version of the wholesale usurpation doctrine appears

and the copying of 24 passages. See 181 F.2d at 666 . The court also decided that the defendant did not make a fair use of those concepts and passages. Professor Denicola apparently believes that Toksvig may represent too "parsimonious" an application of the fair use doctrine, but fits this case into his scheme of according protection to the assemblage of facts in a nonfiction narrative and relying on fair use to determine whether there has been a bodily appropriation. See Denicola, supra note 22, at 538-39.

${ }^{308}$ For a discussion of protection under the misappropriation theory, see $1 \mathrm{M}$. Nimmer, supra note 73 , at $\$ 2.10$ [E] n.30 (collecting cases); Gorman, supra note 3 , at 598-610.

${ }^{309}$ Miller v. Universal City Studios, 650 F.2d 1365, 1372 (5th Cir. 1981).

310 Denicola, supra note 22, at 530 .

311 Id. at 519.

312 Sony Corp. v. Universal City Studios, 464 U.S. 417, 429 (1984). 
as part of fair use analysis in cases such as Rosemont Enterprises $v$. Random House, Inc. ${ }^{318}$ In Rosemont, the plaintiff sought and obtained a preliminary injunction against the distribution of the defendant's unauthorized biography of Howard Hughes. The plaintiff argued that the biography infringed its copyrights in a series of magazine articles about Hughes. ${ }^{314}$

The court of appeals vacated the injunction. In its infringement analysis, the court noted that the similarity between the biography and the articles was attributable, at least in part, to the fact that there was common source material used by both parties. ${ }^{315}$ This fact suggested that any similarity would be considered "innocent similarity" under Orgel. The court went on, however, to add that the plaintiff could claim protection only in the expression, and "could not acquire by copyright a monopoly in the narration of historical events." 316 This reasoning suggested that similarity based on common factual information would not be a ground for finding infringement regardless of whether the defendant obtained the information from a common source or from the plaintiff's work. With respect to the protected expression, the court expressed "considerable doubt as to whether the copied and paraphrased matter constitute[d] a material and substantial portion of those articles." 312 The court stated that "the material at most form[ed] an insubstantial part" of the plaintiff's biography. ${ }^{318}$ Rather than concluding that the admitted similarity did not constitute infringement, the court continued with a fair use analysis. The court applied the traditional fair use criteria ${ }^{319}$ and held that the defendant's use was a fair use. $^{320}$

Finally, the court dealt with the wholesale usurpation approach

313366 F.2d 303, 310 (2d Cir. 1966).

sit See id. at 304 .

s18 See id. at 306.

s16 Id.; see also id. at 309-10 (discussing the requirement that the defendant have undertaken independent research of historical facts).

s17 Id. at 306.

818 Id. The lower court held that the fair use defense was inapplicable because the defendant's work was insufficiently "scholarly" and was published "for commercial purposes." See id. at 308. The court of appeals agreed with the defendant that the lower court had defined the fair use doctrine too narrowly. See id.

s10 The factors considered in a fair use determination are codified at 17 U.S.C. $\S 107$ (1982), reprinted supra note 13.

320 See Rosemont, 366 F.2d at 306. The court held that it is "reasonable and customary" for subsequent biographers to use earlier works, including occasional quotations from earlier works. See id. at 307. This use "is permitted because of the public benefit in encouraging the development of historical and biographical works and their public distribution, e.g., so 'that the world may not be deprived of improvements, or the progress of the arts be retarded." "Id. (quoting Sayre v. Moore, 102 Eng. Rep. 138, 139 (K.B. 1801)). 
outlined in Huie and Orgel. In its attempt to clarify this approach, however, the court succeeded only in redirecting the doctrinal confusion down another channel-fair use. The court rejected the district court's argument that an author is not entitled to utilize the "fruits of another's labor in lieu of independent research." "321 Nevertheless, the court held that Orgel and Huie, which employed the "fruits of labor" theory, were consistent with the rejection of the lower court's ruling because those cases stood merely for the proposition that a subsequent author could not "bodily appropriate" the research of the prior author. According to the Rosemont court, "bodily appropriation" meant only that "extensive verbatim copying or paraphrasing of material set down by another cannot" constitute fair use. ${ }^{322}$

The Rosemont decision is problematic for several reasons. First, it is not clear why the court engaged in a fair use analysis in light of its "considerable doubt" that the defendant copied a substantial portion of the plaintiff's copyrightable expression. Further, it is unclear whether the court's doubt in this regard was predicated on the fact that any similarity was due at least in part to common sources, or whether the similarity was related to the use of noncopyrighted material from the plaintiff's work. Second, the court did not disclose whether, in its fair use analysis, it focused on only the quoted or verbatim portion of the articles used by the defendant, or whether it looked at all similarities between the two works. If the latter is the case, then the court was at least in part deciding what should have been issues of copyrightability and infringement-whether the defendant's use infringed the plaintiff's materials considered as a whole, including noncopyrightable portions-in the context of fair use. ${ }^{323}$ Third, the court, in relying on public interest as a separate fair use factor, injected first amendment considerations into the fair use stage, when it should have accommodated these concerns at the copyrightability or infringement stages. Fourth, and most importantly for the present examination, the court purported to rely on Orgel and Huie in rejecting the "fruits of labor" theory and in establishing a prohibition on "bodily appropriation," defined as "extensive verbatim copying or paraphrasing of material." It is clear, how-

321 Id. at 310 .

s22 Id. Indeed, in evaluating the commercial purpose prong of fair use analysis, see 17 U.S.C. $\$ 107(1)$ (1982), reprinted supra note 13 , the Rosemont court characterized Huie and Oxford as fair use cases. See 366 F.2d at 308.

323 To some degree, the court's analysis reflects an earlier notion that fair use meant copying the ideas in a work, rather than the expression. See, e.g., Shipman v. R.K.O. Radio Pictures, Inc., 100 F.2d 533 (2d Cir. 1938); Sheldon v. Metro-Goldwyn Pictures Corp., 81 F.2d 49 (2d Cir.), cert. denied, 298 U.S. 669 (1936). This notion certainly imports copyrightability doctrine into fair use analysis. 
ever, that in Orgel and Huie the notion of "bodily appropriation" was not part of fair use; rather, it was an infringement doctrine prohibiting the use of an unacceptable amount of material acknowledged to be in the public domain.

After Rosemont, two cases adopted a hybrid "wholesale usurpation" analysis; they maintained Rosemont's conclusion that the wholesale usurpation issue is part of fair use analysis, but they also returned to the "fruits of labor" rationale espoused by Orgel and Huie. In Meredith Corp. v. Harper $\&$ Row, Publishers, ${ }^{324}$ the plaintiff obtained a preliminary injunction after alleging that its psychology textbook was infringed by the defendant's text, which the court found was a "conscious paraphrasing" of the plaintiff's text. ${ }^{325}$ The court did not bother to determine whether the admitted similarity was attributable to facts about psychology that were in the public domain or whether the paraphrasing was such as to constitute minimal "distinguishable variation" required to defeat a finding of substantial similarity when the underlying facts are in the public domain. ${ }^{326}$ Rather, the court went directly to the fair use doctrine and, relying on the Rosemont interpretation of Orgel, held that the defendant had engaged in extensive paraphrasing of the plaintiff's expression and had copied "the entire structure and topical sequence" of the plaintiff's book. ${ }^{327}$ The court also quoted Orgel's prohibition against appropriating the fruits of another's labor in lieu of independent research and emphasized that failing to protect the plaintiff's work would remove the incentive for someone like the plaintiff to invest considerable time and energy in research and scholarship. $^{328}$

In the second hybrid case, Wainwright Securities Inc. v. Wall Street Transcript Corp. ${ }^{328}$ the court of appeals affirmed a preliminary injunction against the defendants, who had published abstracts of the plaintiff's institutional research reports. The court recognized that news events and factual information, as distinguished from their expression, could not be copyrighted, but then proceeded to define the protectible expression as "the manner of expression, the author's analysis or inter-

324378 F. Supp. 686 (S.D.N.Y.), affd, 500 F.2d 1221 (2d Cir. 1974).

325 See id. at 688.

${ }^{328}$ See, e.g., Concord Fabrics, Inc. v. Generation Mills, Inc., 328 F. Supp. 1030, 1032 (S.D.N.Y. 1971); Lauratex Textile Corp. v. Citation Fabrics Corp., 328 F. Supp. 554, 555-56 (S.D.N.Y. 1971).

${ }_{327}$ Meredith, 378 F. Supp. at 690.

${ }^{328}$ See id. Another example of a court employing more than one approach to an infringement claim can be found in Gardner v. Nizer, 391 F. Supp. 940 (S.D.N.Y. 1975). For a discussion of Gardner, see supra note 212.

${ }_{328} 558$ F.2d 91 (2d Cir. 1977), cert. denied, 434 U.S. 1014 (1978). 
pretation of events, the way he structures his material and marshals facts, his choice of words, and the emphasis he gives to particular developments." 330

Having defined the protectible expression broadly, the court easily concluded that the district court was correct in holding that the defendants' appropriation was not privileged under fair use doctrine. The court noted that "[u]nlike traditional news coverage, ... . [the defendants' work] did not provide independent analysis or research" and that the defendants appropriated those portions of the plaintiff's works that represented "a substantial investment of time, money and labor."331 The court also stated that the defendants' appropriation was intended to fulfill the demand for plaintiff's work, thus amounting to "chiseling for personal profit."'332

The Wainwright court could have resolved the case without relying on either its extremely broad definition of protectible expression or any finding of usurpation of the plaintiff's time and labor. The court characterized the defendants' appropriation as "almost verbatim"s33 and could easily have affirmed the lower court even under the restrictive standards of copyrightability found in Oxford and Rosemont. All prior cases were in agreement that verbatim reproduction of expression infringes copyright unless excused by fair use. In light of its holding that the use was intended to supplant the plaintiff's work and Rosemont's holding that extensive verbatim copying could not constitute fair use, the Wainwright court could have decided the case on traditional fair use grounds alone.

In addition to being doctrinally inconsistent with Orgel and Huie, the fair use version of the wholesale usurpation doctrine involves totality concerns in three respects. First, the doctrine presents too great a

sso Id. at 95-96. This definition was derived from the standard for distinguishing unprotectible ideas from protectible expression articulated in an earlier case involving fictional works. See Reyher v. Children's Television Workshop, 533 F.2d 87, 91 (2d Cir.), cert. denied, 429 U.S. 980 (1976). In some respects, this definition of expression appears to accord with the Second Circuit's theory in The Nation that the mode of expression of factual works includes the "total entity." See 723 F.2d at 203. To the extent that Wainwright's definition of "expression" also includes analysis or interpretation of factual events, it is clearly inconsistent with Hoehling. See Hoehling, 618 F.2d at 978 .

In addition to the fair use argument, the defendants in Wainwright argued that the plaintiff's reports were financial "news" and that the defendants" "coverage" of that news was protected under the first amendment. The court quickly disposed of the first amendment argument, holding that any conflict between the first amendment and copyright law in this case could be resolved by application of the fair use doctrine. See Wainwright, 558 F.2d at 95.

${ }^{331}$ Wainwright, 558 F.2d at 96.

ss2 Id. at 97 .

sss Id. at 96 . 
temptation to consider factual information protectible for copyrightability and infringement purposes and then to "compensate" by considering an absence of wholesale usurpation as support for the defendant's claim of fair use, thus enlarging the scope of the fair use privilege. This approach has been accepted by Professor Denicola, who argues that at least until Hoehling, Second Circuit copyright jurisprudence-represented most notably by Rosemont and Huie-provided, and should continue to provide, protection for "particular assemblage[s] of facts" in nonfiction narratives and collections of factual data. ${ }^{334}$ According to Denicola, this protection does not threaten to violate the axiom that facts are noncopyrightable, because the magnitude of appropriation must be considered as a factor in both infringement and fair use determinations. ${ }^{335}$ Denicola's proposal would increase the number of instances in which courts would find substantial appropriation or infringement and defendants would be required to rely directly on the fair use defense. The fair use inquiry would in turn focus on whether the defendant "bodily appropriated" the factual aggregation.

The problem here is apparent. Denicola accepts a totality approach that accords copyright protection, beyond mere protection for arrangement, to groups of elements that taken individually are not copyrightable. He assures us that this expanded copyright protection will not conflict with either basic copyright purposes or first amendment concerns. ${ }^{336}$ The plaintiff will still have to show that the defendant substantially appropriated the assemblage of facts by reproducing some substantially similar subset of those facts. Even if the plaintiff makes this showing, the defendant may still argue, in the context of fair use analysis, that it did not bodily appropriate the assemblage. But a fair use doctrine that includes a wholesale usurpation concern does not guarantee that there will be the same level of dissemination of facts as there would be if factual information were simply deemed unprotectible. There are other factors involved in a fair use inquiry, and these factors may weigh more heavily against the magnitude-of-use consideration. Relying on fair use is always much riskier for defendants than relying on copyrightability or infringement doctrines because of the inherently ad hoc nature of the fair use doctrine.

Second, it is clear that courts that have applied the wholesale usurpation standard as a fair use factor have been concerned about a subsequent author expropriating the fruits of a prior author's labors in the

ss4 Denicola, supra note 22, at 538 .

s35 See id. at 538-39.

sss See id. at 540-41. 
absence of independent research. ${ }^{337}$ It is no more acceptable to accord copyright protection to the fruits of labor at the fair use stage, however, than it is at the initial stages of copyrightability or infringement: the "fruits of labor" theory is a totality approach at any stage of analysis. Professor Denicola defends this use of the labor theory of copyright by reasoning that in fair use analysis it is appropriate to consider whether the defendant is using factual material to add to earlier contributions. ${ }^{338}$ If the defendant is relying primarily or entirely on the plaintiff's labor or research, then public benefit resulting from the use decreases and the use is not "fair." because it assumes that the plaintiff's research or labor can be protected by copyright in the first place. If information is in the public domain, then there is no infringement and fair use does not apply; one should not be able to obtain copyright protection for that information by going through the back door of fair use.

Third, the cases exhibit confusion over whether fair use is to be determined only after the factfinder decides that there is substantial similarity, ${ }^{340}$ or whether a finding of fair use is tantamount to a finding of the absence of substantial similarity. ${ }^{341}$ Part of the reason for this confusion is that one of the fair use factors is the substantiality of the portion used by the defendant. ${ }^{342}$ Although factfinders are apparently allowed to consider the quality as well as the quantity of the taking in deciding substantiality, there may be a temptation to engage in totality analysis by considering noncopyrightable material in making the qualitative examination. ${ }^{343}$ This totality concern is exacerbated when the

${ }^{337}$ See, e.g., Benny v. Loew's Inc., 239 F.2d 532, 536 (9th Cir. 1956) (holding, under a fair use analysis, "that a writer may be guided by earlier copyrighted works ... . [but] if he appropriate[s] the fruits of another's labors, without alteration, and without independent research, he violates the rights of the copyright owner"), affd, 356 U.S. 43 (1958).

338 See Denicola, supra note 22, at 538-39.

sso See id. at 538 .

s40 This interpretation seems consistent with the way in which fair use is characterized in the 1976 Copyright Act. See 17 U.S.C. $\S 107$ (1982), reprinted supra note 13.

s41 See, e.g., Bradbury v. Columbia Broadcasting Sys., 287 F.2d 478, 485 (9th Cir.), cert. dismissed, 368 U.S. 801 (1961); Shipman v. R.K.O. Radio Pictures, Inc., 100 F.2d 533, 537 (2d Cir. 1938); Sheldon v. Metro-Goldwyn Pictures Corp., 81 F.2d 49, 54 (2d Cir. 1936).

s\$2 17 U.S.C. $\$ 107(3)$ (1982), reprinted supra note 13 . For cases involving the substantiality factor, see, for example, Marcus v. Rowley, 695 F.2d 1171, 1177 (9th Cir. 1983); Meredith Corp. v. Harper \& Row, Publishers, 378 F. Supp. 686, 689 (S.D.N.Y.), affd, 500 F.2d 1221 (2d Cir. 1974).

${ }^{343}$ For instance, in discussing this fair use factor, the Fifth Circuit pointed out that the user who reproduced the covers of $T V$ Guide in comparative advertising "did not copy what is the essence of TV Guide-the television schedules and articles." Triangle Publications v. Knight-Ridder Newspapers, 626 F.2d 1171, 1177 (5th Cir. 
wholesale usurpation notion is introduced into fair use analysis; the factfinder may unwittingly consider the quantity taken without considering whether the portions appropriated were protectible. This problem was demonstrated in Meredith, in which the district court, relying on Rosemont, Huie, and Orgel, focused exclusively on the quantity of information taken to deny the defendant's claim of fair use. ${ }^{344}$ The court in Meredith never bothered to consider issues of qualitative taking relating to copyrightability or infringement standards.

\section{Wholesale Usurpation and Protectible Arrangements}

The third branch of the wholesale usurpation doctrine accords to nonfiction narratives protection similar to that given to compilations or collections of facts. It is generally accepted that the arrangement and, in some cases, even the selection of factual matter in materials such as directories are protected under copyright law, ${ }^{345}$ but there is no generally accepted view concerning the scope of that protection. Some directory cases even go so far as apparently to protect the data contained in the directories. ${ }^{346}$

In certain respects, this version of the doctrine can be traced back to Hoehling. The commentators seem to agree that Hoehling stands for the proposition that nothing short of a wholesale usurpation of literal expression will support a finding of infringement when dealing with factual works. ${ }^{347}$ In Hoehling, the Second Circuit applied a dissection approach insofar as subject matter totality was concerned, but, relying on Wainwright, cautioned against sanctioning "wholesale usurpation" or "verbatim reproduction" of expression. ${ }^{348}$ What is confusing here is that Hoehling made it appear as though actual expression could be used as long as the works were not "virtually identical" in expression. ${ }^{348}$ It should be noted, however, that the claim in Hoehling was apparently not that the defendants appropriated actual expression, but rather that the defendants appropriated a plot and certain facts that,

1980). Because the schedules reflect factual information, factfinders looking at qualitative taking may be considering material that is per se noncopyrightable.

s44 See 378 F. Supp. at 689-90, discussed supra notes 324-28 and accompanying text.

345 The 1976 Copyright Act specifically provides for the protection of compilations. See 17 U.S.C. $\S 101$ (1982) (definition of compilations); 17 U.S.C. $\S 103$ (1982) (scope of protection).

${ }^{346}$ See, e.g., Leon v. Pacific Tel. \& Tel. Co., 91 F.2d 484 (9th Cir. 1937) (holding that a directory with sequential telephone numbers infringed the copyright in an existing alphabetical directory).

347 See, e.g., Denicola, supra note 22, at 539; Gorman, supra note 3, at 593-94.

${ }^{348}$ See Hoehling, 618 F.2d at 979-80.

s49 See id. 
according to the plaintiff, were copyrightable. The court refused to recognize that factual information could be copyrighted as the fruit of one's labor. To the extent that phraseology was identical, the court found that these similarities all related to scenes a faire. ${ }^{350}$ Further, the court did not dispute that the applicable standard of analysis for infringement was whether there had been a wrongful appropriation of protectible expression resulting in substantial similarity. ${ }^{361}$ It appears that Hoehling was not seeking to replace substantial similarity with wholesale usurpation; its references to the latter probably reflected some version of the doctrine employed in Huie, Orgel, Meredith, and Wainwright.

The wholesale usurpation doctrine that Hoehling hints at appears most clearly in the court of appeals decision in The Nation. This opinion was written by Judge Kaufman, who also wrote Hoehling. In The Nation, Judge Kaufman made it clear that protectible "expression" can have two meanings. First, the narrow definition of "expression," derived from the copyright axiom that facts are not protectible, is "the ordering and choice of the words themselves."362 Under this definition, "paraphrasings of disparate facts" are not prohibited. ${ }^{363}$ If, however, the subsequent author seeks to paraphrase or mimic the "total entity," then Wainwright and Meredith establish that expression understood broadly as a "total entity" would be wrongfully appropriated. ${ }^{\text {s54 }}$ This

sso See id. at 979 .

ss1 See id. at 977 . The reliance in Hoehling on Myers v. Mail \& Express Co., 36 Copyright Office Bull. 478 (S.D.N.Y. 1919) (L. Hand, J.), see supra note 283 and accompanying text, is confusing but not necessarily inconsistent with the reading of Hoehling presented in the text. With respect to a historical work, the sequence and selection of events may not be copyrightable, and the disparate facts, per se noncopyrightable, could be used with minor variations. Nevertheless, the "total entity" might still be protected against "bodily appropriation" of research if a subsequent user tried merely to "rewrite" the entire original by paraphrasing each statement.

In addition, the Hoehling court relied on Rosemont for the proposition that a historical work could be infringed by a "bodily appropriation" of the "expression" in the work. See Hoehling, 618 F.2d at 980 . This reliance indicates either that Judge Kaufman used "expression" to mean the protected "mosaic" or structure (as he did in The Nation), or that he was referring to the rather confusing aspect of Rosemont that transformed bodily appropriation into a fair use factor. Given the context of Hoehling, which did not involve fair use analysis, the former interpretation is more likely.

${ }_{382}$ The Nation, 723 F.2d at 204.

sss Id. at 203. Judge Kaufman explicitly repudiated the labor theory. See id. at 203 n.11. As discussed below, see infra notes 354-66 and accompanying text, it would be nonsensical to reject the labor theory if there is some appropriation, but to accept it if there is complete appropriation. Nevertheless, in Miller v. Universal Gity Studios, 650 F.2d 1365 (5th Cir. 1981), the court interpreted Hoehling as rejecting the labor theory "absent wholesale appropriation of expression." Id. at 1369 n.3; see also Eckes v. Card Prices Update, 736 F.2d 859, 862 (2d Cir. 1984) (rejecting protection based on the labor theory "absent, perhaps, wholesale appropriation").

s54 It should be noted that both Wainwright and Meredith relied on the notion 
protection arises because the structure of the work can constitute an original writing legitimately protected by copyright law, not because the fruits of labor merit copyright protection. ${ }^{365}$

Using this distinction, Judge Kaufman stated:

In this case, there can be no concern that this mode of expression was usurped; The Nation article drew only upon scattered parts and not the total entity with its unique and protected mosaic.

If The Nation had taken, for example, all of the book or all of a chapter and merely changed the language here and there, paraphrasing would not and should not suffice to protect it. ${ }^{358}$

In these passages, the court defined a second "mode of expression," distinguishable from the word-for-word literal expression that the court held could be appropriated through paraphrasing because of the noncopyrightability of factual information. This second type of expression consists of the author's structure and arrangement of facts and is characterized as the "unique and protected mosaic" of the work.

Any grant of protection to a compilation or directory, or to the selection and arrangement of material in nonfiction narrative, must raise a further question concerning the standard of infringement to be employed. In Hoehling and the court of appeals' opinion in The $\mathrm{Na}$ tion, that standard was usurpation of the "entire totality." Applying this standard to a factual work may appear to be a "totality" approach, because the standard seemingly accords copyright protection to some totality the constituent parts of which may not be protectible. ${ }^{357}$ On further reflection, however, it is clear that as long as the underlying individual facts in the compilation or narrative are not accorded protection, what is protected is only the authorship embodied in the arrangement; the wholesale appropriation standard guarantees that only the arrangement will be protected, and it will be protected only against exact or nearly exact copying.

The difficulty occurs when the standard protects the selection of

that fruits of labor were protectible under copyright law. This notion was rejected by Judge Kaufman in Hoehling.

sss See The Nation, 723 F.2d at 203.

${ }^{358} I d$.

ss7 See, e.g., Leon v. Pacific Tel. \& Tel. Co., 91 F.2d 484 (9th Cir. 1937) (telephone directory); Triangle Publications v. New England Newspaper Publishing, 46 F. Supp. 198 (D. Mass. 1942) (racing report). 
facts as well as the arrangement. ${ }^{358}$ For example, in Meredith, the defendant was held to infringe the plaintiff's arrangement and selection through an extensive taking of "the entire structure and topical sequence" of the facts and theories in the plaintiff's textbook on child psychology. ${ }^{359}$ The problem here is that the selection of relevant topics by the plaintiff logically represents a "theory" or "idea" concerning the relevant topics in a field of social science. If copyright protection is accorded to the selection of noncopyrightable facts, the implication is that an infringement standard that falls short of wholesale appropriation is being used. The result is tantamount to according copyright protection to material that is per se noncopyrightable - that is, a totality approach. ${ }^{\mathbf{3 8 0}}$

Professor Denicola rejects the distinction between arrangement and selection that $I$ argue for here. He maintains that although courts most frequently protect only the arrangement of data appearing in a compilation, this level of protection proves unacceptable because subsequent users will escape liability if they appropriate information but not arrangement. Courts should therefore grant protection to the "particular collection of data." 361 Although this approach finds little support in the case law, ${ }^{362}$ Professor Denicola correctly recognizes a ready analogy in "those cases that emphasize the originality in plaintiff"s selection or choice of data." ${ }^{\text {s6s }} \mathrm{He}$ also properly notes that these cases are based on "skill and taste" " in selection. ${ }^{384}$ What he fails to note is that "skill and taste" represent merely an unprotectible idea or the fruits of the user's labor. He unwittingly but explicitly discusses the most dangerous

${ }^{358}$ For example, if a court applies the substantial similarity test to the use of an arrangement of facts, then there is a danger that use of data within the arrangement that falls short of taking the arrangement itself will be found to be an infringement. Professor Gorman argues that copyright protection in a terse and exhaustive directory should be "thin" and protect only against wholesale appropriation, but that if the directory or compilation contains original prose or artistry, then the ambit of protection ought to increase. See Gorman, supra note 3, at 571-72. Professor Gorman's observation is consistent with the observation made in the text.

350 Meredith, 378 F. Supp. at 690.

380 The selection of premium baseball cards was protected by using a substantial similarity standard in Eckes v. Card Prices Update, 736 F.2d 859 (2d Cir. 1984). It appears, however, that in Eckes there had been a virtual reproduction of expression. See id. at 863 .

${ }^{361}$ Denicola, supra note 22, at 530.

${ }^{382}$ See, e.g., Triangle Publications v. Sports Eye, Inc., 415 F. Supp. 682, 685-86 (E.D. Pa. 1976).

ses Denicola, supra note 22, at 530; see, e.g., College Entrance Book Co. v. Amsco Book Co., 119 F.2d 874, 875-76 (2d Gir. 1941) (plaintiff's choice and translation of vocabulary list protected); List Publication Co. v. Keller, 30 F. 772 (S.D.N.Y. 1887) (defendant prohibited from using social register instead of compiling its own list).

${ }^{364}$ Denicola, supra note 22, at 530-31 (quoting Edward Thompson Co. v. American Law Book Co., 122 F. 922, 924 (2d Cir. 1903)). 
aspect of this protection: "These decisions [on selection or choice] would appear to indicate a willingness to protect at least certain aggregations of facts without the necessity of establishing an additional appropriation of the arrangement or pattern of the copyrighted work."365 That is precisely the problem. As long as only the arrangement is protected against exact or nearly exact copying, then there is no danger that the underlying, noncopyrightable facts will receive incidental copyright protection. Once the protection extends to the selection or choice of those facts, however, the danger increases that copyright protection will be extended in a way that will frustrate both the intent of the copyright law and the constitutional principles that define its ambit. ${ }^{386}$

\section{CONCLUSION}

The controversy in The Nation highlighted important issues involving copyright protection for factual works. The controversy between the district court and the court of appeals focused at least in part on whether noncopyrightable factual material contained in the memoirs somehow acquired copyright protection by being combined with protectible expression into a copyrightable totality. The Supreme Court declined to discuss the merits of the totality approach adopted by the district court and rejected by the court of appeals, but then in its fair use analysis relied to some degree on the findings of the district court, which were predicated on the totality approach. In determining that Navasky's use of the verbatim quotations did not qualify as a fair use, the Court truncated substantially the fair use doctrine. Because the Court has diminished the utility of fair use for accommodating the broad dissemination of factual works indisputably required by the copyright law and the first amendment, it is essential to focus on doctrines of copyrightability and infringement in order to limit a copyright holder's monopoly over a factual work. It is equally essential to maintain the doctrinal distinctions among the three copyright analyses-copyrightability, infringement, and fair use-in order to avoid the confusion that results from totality analysis.

Although the totality approach has surfaced in a confused combination of doctrines involving copyrightability, infringement, and fair

s6B Id. at 531 .

ses Although the 1976 Copyright Act defines a compilation to include a "collection . . . of preexisting materials ... that are selected," 17 U.S.C. $\S 101$ (1982) (emphasis added), to interpret this the way Professor Denicola does would conflict directly with the proscription in section 102(b) against extending copyright protection to any "idea" or "principle." 
use, it has been shown that totality analysis surfaces in distinctly different ways. These versions of totality analysis characterize many copyright decisions, and are all present in one or more of the opinions in The Nation. The totality approach to defining protectible subject matter characterized the district court's opinion, and, perhaps indirectly, the Supreme Court's. Totality analysis and the standard for infringement of protectible expression formed the basis for part of the dispute between the district court and the court of appeals. Finally, rejection of the totality approach as it is applied to the wholesale usurpation doctrine played a role in the court of appeals opinion.

In all of its manifestations, the totality approach has the same unfortunate result: it accords copyright protection to material that is per se noncopyrightable, thereby frustrating the basic purpose of copyright law and increasing the tension between copyright and the first amendment. Facts are not copyrightable, and courts must use various devices, such as excision of noncopyrightable material from the scope of protectible expression, application of a more narrow standard of infringement to factual works, and a cautious approach to protecting expression other than literal expression, in order to assure broad availability of factual works. If the totality approach is not severely limited, copyright law will no longer facilitate the widespread dissemination of factual information. 